Portland State University

PDXScholar

1992

\title{
Mineralogy, geochemistry, and dispersal of opaque oxides on the continental shelf of the Cascadia margin
}

Kommajosyula Subramanya Ravi

Portland State University

Follow this and additional works at: https://pdxscholar.library.pdx.edu/open_access_etds

Part of the Geochemistry Commons, Geology Commons, and the Mineral Physics Commons Let us know how access to this document benefits you.

\section{Recommended Citation}

Ravi, Kommajosyula Subramanya, "Mineralogy, geochemistry, and dispersal of opaque oxides on the continental shelf of the Cascadia margin" (1992). Dissertations and Theses. Paper 4363.

https://doi.org/10.15760/etd.6219

This Thesis is brought to you for free and open access. It has been accepted for inclusion in Dissertations and Theses by an authorized administrator of PDXScholar. Please contact us if we can make this document more accessible: pdxscholar@pdx.edu. 
AN ABSTRACT OF THE THESIS OF Kommajosyula Subramanya Ravi for the Master of science in Geology presented May 26, 1992.

Title: Mineralogy, Geochemistry, and Dispersal of opaque oxides on the continental Shelf of the Cascadia Margin.

APPROVED BY THE MEMBERS OF THE THESIS COMMITTEE:

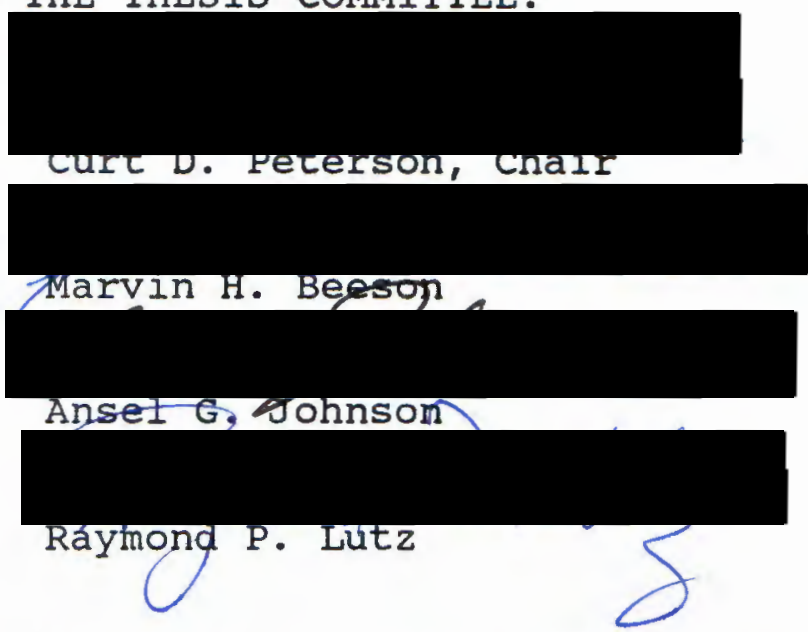

opaque oxide minerals (ilmenite, chromite, and magnetite) in sands from the oregon continental shelf have been studied to establish the provenance, dispersal, and grade of potential shelf placer deposits. The study area extends southward from offshore of the Columbia River in northern Oregon to the Klamath River in northern California. The opaque mineral compositions were determined by instrumental neutron activation analysis (INAA), electron microprobe and standard petrographic microscope. The 
contrasting distributions of chromium-rich oxides (south of $43^{\circ}$ ) and titanium-rich oxides (north of $43^{\circ}$ ) source rocks from the Klamath Mountains (south) and the Coast Range (north) respectively. Linear regressions of specific major and trace element pairs (Co-Cr, Ta-Ti, Hf-Ti, $\mathrm{Sc}-\mathrm{Ti}$ and $\mathrm{V}-\mathrm{Fe}$ ) demonstrate trace element partitioning into the dominant opaque mineral phases (Cr-rich chromite, Tirich ilmenite and the Fe-oxide magnetite). The trace element partitioning is based on valence and ionic radii constraints. Factor analysis of combined shelf-beach-river geochemical data yield distinct factors which correspond with onshore provenances. Four principal opaque mineral sources that are identified by factor analysis include:

a Klamath Mountain terrain in the southern shelf, (2) a Coast Range terrain in the northern shelf, (3) a north Klamath source terrain and (4) a columbia River source, the four factors accounting for over $95 \%$ of the data variance. Contour maps containing opaque- and non-opaque mineral chemistry and Fourier grain-shape analysis of quartz grains establish contrasting dispersal patterns on the shelf. The shelf opaque- and non-opaque oxide mineral geochemistry demonstrate dominantly west-east and south-north dispersal patterns respectively. The results from grain-mineral and grain-size distributions from six samples off Cape Blanco suggest the potential for a shelf winnowing process of heavy mineral concentration, supporting an offshore origin for the 
shelf heavy mineral (HM) concentrations. The shelf winnowing process, possibly forced by focusing of storm geostrophic currents around headlands could account for the association of shelf $\mathrm{HM}$ concentrations around major headlands. 
MINERALOGY, GEOCHEMISTRY, AND DISPERSAL OF OPAQUE OXIDES ON THE CONTINENTAL SHELF OF THE CASCADIA MARGIN

by

KOMMAJOSYULA SUBRAMANYA RAVI

A thesis submitted in partial fulfillment of the requirements for the degree of

MASTER OF SCIENCE

in

GEOLOGY

Portland state University

1992 
TO THE OFFICE OF GRADUATE STUDIES:

The members of the Committee approve the thesis of Kommajosyula Subramanya Ravi presented May 26, 1992.

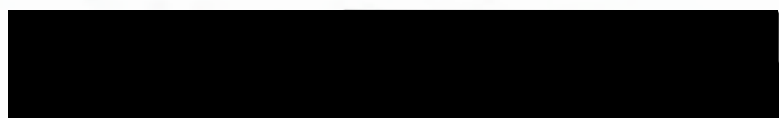

curt D.' Peterson, chair

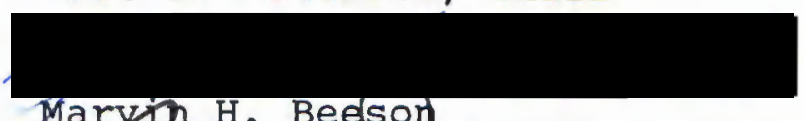

Maryin H. Beeson a

Anse 1 Go Joknson

Raymong P. Lutz
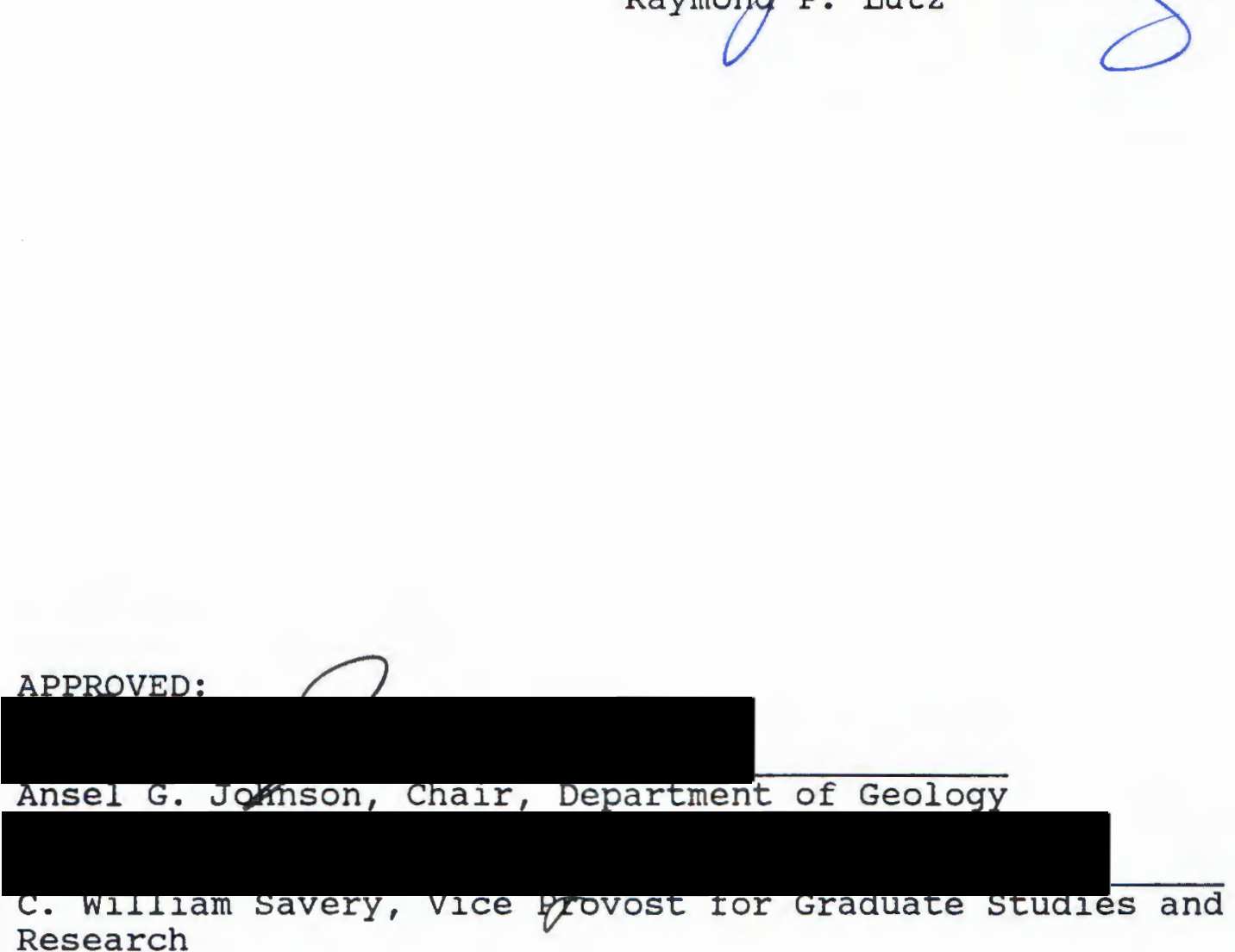
Research 


\section{ACKNOWLEDGEMENTS}

I would like to express my sincere gratitude to Dr. Curt D. Peterson for his support, guidance and patience throughout this study. I would also like to thank his wife, Carolyn Peterson for accepting me as part of their family. Thanks to Dr. Marvin H. Beeson, who taught me traceelement geochemistry and provided advice and encouragement on numerous occasions. I would like to thank Dr. Ansel G. Johnson who introduced me to mathematical and statistical geology. I thank Drs. M.L.Cummings, R.E.Thoms, P.E.Hammond and S.F.Burns for their enthusiasm and dedication, which have been a constant inspiration to me.

I thank Margaret Mumford and Dr. Roger Nielson of Oregon State University's College of Oceanography for providing me with bulk opaque oxide splits and for helping me with the electron microprobe techniques.

Special thanks to Drs. Dreisen, Michael Bower, Eric Freidman, Gilbert Lipschutz, Janet Murphy and Ronald Dworkin of Providence Medical Center for treating me for the tuberculosis and pulmonary embulus. Without their incredible efforts and humanitarian concerns, my life would not have been the same. 
I would like to thank my parents Dr. K.V.N. Rao and Latha and to my family members DR. N. Rao and S. Ram, for their unending support and love, without which I would not have had the opportunity to pursue this degree. And lastly, I would like to thank charles clough for assisting with the figure drafting. 
TABLE OF CONTENTS

PAGE

ACKNOWLEDGEMENTS ......................... ii

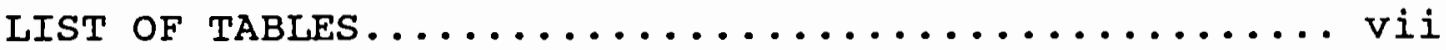

LIST OF FIGURES.................... ix

CHAPTER

I INTRODUCTION $\ldots \ldots \ldots \ldots \ldots \ldots \ldots \ldots$

II $\quad$ STUDY AREA $\ldots \ldots \ldots \ldots \ldots \ldots \ldots \ldots \ldots$

III REGIONAL GEOLOGY $\ldots \ldots \ldots \ldots \ldots \ldots \ldots$

Klamath Mountains............... 11

IV PREVIOUS WORK ON MARINE PLACERS $\ldots \ldots \ldots \ldots 17$

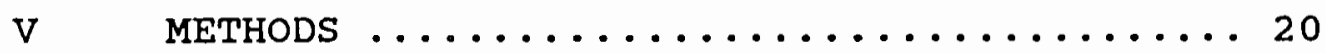

Sample Description .............. 20

Sample separation .............. 23

Sample Encapsulation ............ 27

Instrumental Neutron Activation-

Analysis (INAA) $\ldots \ldots \ldots \ldots \ldots \ldots \ldots \ldots$

Electron Microprobe ............. 30

VI $\quad$ RESULTS $\ldots \ldots \ldots \ldots \ldots \ldots \ldots \ldots \ldots \ldots \ldots \ldots$

INAA of Continental Shelf Deposits ..... 34

Mineral-Grain Hydrodynamic Relations .... 69 
Microprobe Analysis of Shelf

Opaque Minerals $\ldots \ldots \ldots \ldots \ldots \ldots \ldots 76$

VII DISCUSSION $\ldots \ldots \ldots \ldots \ldots \ldots \ldots \ldots \ldots \ldots$

Shelf Opaque Dispersal Patterns (Q-mode Factor Analysis) $\ldots \ldots \ldots \ldots \ldots \ldots \ldots$ Contour Maps Comprising Dispersal of opaque oxide-, Non-opaque Minerals and Quartz Grain Rounding ............ 98 Relationships of the Various Hydrodynamic Models .............. 101 Mineral Economic Grade and Silicate Contaminants ................ 106 VIII CONCLUSIONS .................... 109 APPENDICES

A ELEMENTAL COMPOSITIONS OF BULK OPAQUE MINERAL SPLITS FROM THE SHELF BY INSTRUMENTAL NEUTRON ACTIVATION ANALYSIS.............. 119

B DETAILED FACTOR LOADINGS .......... 128

C CONTOUR MAPS $\ldots \ldots \ldots \ldots \ldots \ldots \ldots \ldots \ldots \ldots$ 


\section{LIST OF TABLES}

TABLE

PAGE

I Heavy Minerals and Metals in Marine Placers

of the Pacific Northwest USA .......... 22

II Radionuclides and INAA Parameters ........ 31

III Elemental correlation coefficients for

Opaque Mineral Fraction of River, Beach, and Shelf Sands in Oregon and Northern

California, 40.5-46.5 Degrees Latitude .. 47

IV Preliminary Grain Size Frequencies of Opaque

Mineral Distributions in the sixes River,

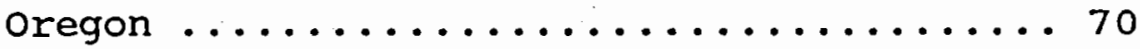

V Calculated statistical parameters for

Magnetite, Quartz, and Bulk samples from

the Cape Blanco shelf ............... 74

VI Microprobe Analysis of Averaged Elemental

Compositions of Ilmenite from the selected Shelf Placer Minerals .............. 78

VII Microprobe Analysis of Averaged Elemental

Compositions of Chromite from the selected

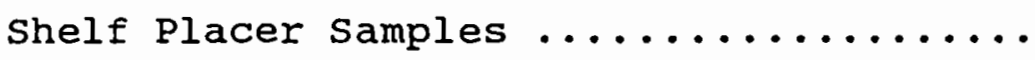


VIII Microprobe Analysis of Averaged Elemental

Compositions of Magnetite from the selected

Shelf Placer Samples ............. 85

IX General Statistics for Element Abundances in

Shelf Opaque Separates ............ 88

$X$ Element Factor Scores for the Combined River,

Beach, and Shelf Sample set......... 90

XI Factors Loadings for Four Factors of

Elemental Composition ............ 93

XII Summary of Average Shelf Microprobe Analysis.. 108 


\section{LIST OF FIGURES}

FIGURE

PAGE

1. Area of Investigation in Relation to

Northwestern United States and Northeastern Pacific Ocean ................. 6

2. General Tectonic Map for the Subduction

Regime and Geologic Provinces in the study Area $\ldots \ldots \ldots \ldots \ldots \ldots \ldots \ldots \ldots \ldots \ldots$

3. Potential source Rocks of the continental

Shelf Sediments from Coastal Drainages and Interior Continental Regions of the Pacific Northwest, including the Klamath-Mountain provenance in southern oregon and northern California and the northern Oregon Coast Ranges (Modified from Wells et al.,1984)... 10

4. Geologic Map of Klamath Mountain Province in North western California and Southwestern Oregon (From Irvin, 1966) ........... 12

5. Physiographic Divisions of western Oregon ... I5

6. Location Map of Shelf Samples used in INAA and Electron Microprobe analysis ....... 21

7. Sample Separation Scheme: Preliminary sieving $(250 \mathrm{~mm})$ was used to screen off the rock fragments and multimineralic aggregates ... 25 
8. Plot of the Major Element Chromium of Bulk Opaque Mineral Separates from the continental Shelf as a Function of Latitude ........ 36

9. Plot of the Major Element Titanium of opaque Mineral Separates from the Continental Shelf as a Function of Degrees Latitude ...... 37 10. Across-shelf Transect of Chromium and Titanium Elemental Abundance for the Samples from 41-42 Degrees Latitude ............ 38

11. Across-shelf Transect of Chromium and Titanium Elemental Abundance for the Samples from 42-43 Degrees Latitude ............. 39

12. Across-shelf Transect of Chromium and Titanium Elemental Abundance for the Samples from 43-44 Degrees Latitude ............. 40

13. Across-shelf Transect of Chromium and Titanium Elemental Abundance for the Samples from 44-45 Degrees Latitude ............. 41

14. Across-shelf Transect of Chromium and Titanium Elemental Abundance for the Samples from 45-46 Degrees Latitude .............

15. Plots of the Major Element ( $\mathrm{Fe}, \mathrm{Cr}$, and $\mathrm{Ti}$ ) Abundances as a Function of Latitude are shown for the opaque mineral separates from the shelf of placers........... 44 
16. Plots of Chromium and cobalt Elemental Values of Opaque Mineral Oxides from the Continental shelf $\ldots \ldots \ldots \ldots \ldots \ldots \ldots \ldots$

17. Plots of Titanium and Hafnium Elemental Values of Opaque Mineral oxides from the Continental shelf ............... 50

18. Plots of Titanium and Scandium Elemental Values of opaque Mineral Oxides from the Continental shelf $\ldots \ldots \ldots \ldots \ldots \ldots \ldots \ldots$

19. Plots of Iron and Vanadium Elemental Values of Opaque Mineral oxides from the

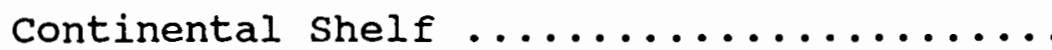

20. Plot of Lanthanum Elemental Abundance as a Function of Degrees Latitude......... 54

21. Plot of Cerium Elemental Abundance as a

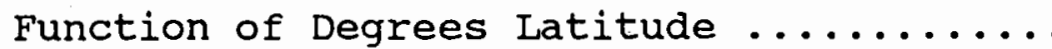
55

22. Plot of Samarium Elemental Abundance as a Function of Degrees Latitude ........ 56 23. Plot of Europium Elemental Abundance as a Function of Degrees Latitude $\ldots \ldots \ldots \ldots$

24. Plot of Ytterbium Elemental Abundance as a Function of Degrees Latitude $\ldots \ldots \ldots \ldots .58$ 25. Plot of Lutecium Elemental Abundance as a Function of Degrees Latitude ......... 59 26. Plot of Hafnium Elemental Abundance as a Function of Degrees Latitude ......... 60 
27. Plot of Tantalum Elemental Abundance as a Function of Degrees Latitude .......... 61

28. Chondrite-Normalized REE Distributions in Shelf Opaque Oxide Minerals Derived from Klamath Mountain Provenance (north of 41-42 degrees latitude) $\ldots \ldots \ldots \ldots \ldots \ldots \ldots \ldots$

29. Chondrite-Normalized REE Distributions in Shelf Opaque oxide Minerals Derived from Coast Range Provenance (north of 43-44 degrees latitude) $\ldots \ldots \ldots \ldots \ldots \ldots \ldots 64$

30. Chondrite-Normalized REE Distributions in Shelf Opaque Oxide Minerals Derived from Columbia River Provenance (north of 45-46 latitude) $\ldots \ldots \ldots \ldots \ldots \ldots \ldots \ldots \ldots \ldots$

31. Distributions of Shelf opaque Oxide Minerals on a La/Sm Ratio vs Latitude Diagram .....66 66 32. Distributions of Shelf Opaque Oxide Minerals on a La/Yb Ratio vs Latitude Diagram .....67 67

33. Distributions of Shelf Opaque Oxide Minerals on a Ce/Yb Ratio vs Latitude Diagram .....66 68

34. Location Map and Heavy Mineral Concentrations in Short Box Cores used in Mineral Grain-Size Statistics (Modified from Kulm,

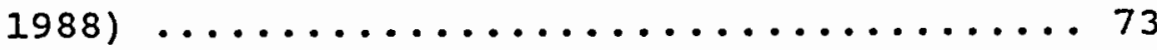

35. Major Elemental ( $T i, F e)$ Distributions in the Ilmenite Phase as a Function of Latitude... 79 
36. Trace Element Contaminants in the Shelf

Ilmenite Grains as a Function of Latitude. . 80

37. Major Elemental ( $\mathrm{Cr}, \mathrm{Fe}$ ) Distributions in the

Chromite Phase as a Function of Latitude... 83

38. Trace Element contaminants in the Shelf

Chromite Grains as a Function of Latitude.. 84

39. Major Elemental (Fe, Ti), Distributions in the Magnetite Phase as a Function of Latitude.. 86

40. Plot of Combined Shelf and onshore Factor 1

Loadings as a Function of Latitude ...... 94

41. Plot of Combined Shelf and Onshore Factor 2

Loadings as a Function of Latitude ...... 95

42. Plot of Combined Shelf and onshore Factor 3

Loadings as a Function of Latitude ...... 96

43. Plot of Combined Shelf and Onshore Factor 4

Loadings as a Function of Latitude ...... 97

44. Hydraulic Settling Equivalence Model (Komar and Wang, 1984; Komar, 1988) for the formation of heavy minerals involves process of selective entrainment and sorting according to their contrasting grain densities and sizes. The opaque- and non-opaque minerals are denoted by closed and open circles respectively .... 102 
45. Kulm's hypothesis (1988) and Phillip's

hypothesis (1979) relating to the

formation of beach placers........... 104 
CHAPTER I

INTRODUCTION

Heavy mineral concentrations in marine deposits, i.e., marine placers, are of interest to geologists as sources of economic minerals, and as distinct indicators of specific transport mechanisms and depositional environments. Marine placers have been investigated in beaches and continental shelves of Africa (Beiersdorf et al., 1980), India (Mallik, 1986), Australia (Kudrass, 1987), and the Atlantic (Darby, 1984) and Pacific coast (Kulm et al., 1968; Peterson and Binney, 1988) of the United States, among other regions. Heavy mineral enrichment in onshore environments can occur from a variety of potential sorting mechanisms (Rubey, 1933; Slingerland, 1977; Sallenger, 1979; Komar and Wang, 1984). However the relative importances of these sorting mechanisms in offshore environments are generally not known.

A renewed interest in the formation and economic potential of marine placers in the U.S. Pacific Northwest (PNW) region has followed recent reports of abundant ilmenite, a titanium-iron oxide, in onshore placer deposits (Peterson et al., 1987). Historically, the onshore marine placers from southern oregon and northernmost California were mined for gold and chromite (Pardee, 1934; Twenhofel, 
1943; Griggs, 1945). Preliminary analyses of selected sand samples from the oregon shelf also indicate the presence of ilmenite in variable ratios to the remaining two oxide phases, chromite and magnetite (Kulm and Peterson, 1989). However, the aerial distribution, economic grade and origin of potential offshore marine placers from this area have yet to be fully evaluated.

Petrographic studies of the non-opaque, heavy mineral fractions of PNW shelf sands have indicated a general northward littoral transport in Late Quaternary time (Scheidegger et al., 1971; Venkatarathnam and McManus, 1973). Unfortunately, the specific sources and dispersal patterns of the opaque oxide minerals cannot be similarly studied by transmission petrography. However, geochemical analyses of ilmenite and chromite from onshore placers in southern Oregon confirm both local sources, Klamath and Coast Range terrains, and a net northward transport of these minerals during successive transgressions (Lupeke, 1980; Peterson et al., 1986). Such analyses have not yet been performed on equivalent oxide minerals from adjacent shelf deposits in the region.

Heavy minerals, i.e., mineral grain densities greater than $2.9 \mathrm{~g} \mathrm{~cm}^{3}$, in concentrations of 10 to $50 \%$ by weight have been identified in surface deposits of the continental shelf offshore oregon, Washington, and northernmost California (Kulm et al., 1968; Moore and Silver, 1968; 
Venkatarathnam and McManus, 1973). Several different origins have been proposed for these shelf heavy-mineral anomalies including mineral entrapment in embayments (Twenhofel, 1943), reworking of shoreline placers during successive transgressions (Chambers, 1969; Kulm, 1988), winnowing of shelf deposits by offshore currents (Phillips, 1979), and selective mineral entrainment by longshore currents (Peterson et al., 1986).

Recent work by Kulm (1988) suggested that shelf HM concentrations offshore of southern oregon might be derived from (1) placer mineral accumulations on the beach faces with, (2) the subsequent reworking of the beach face placers during a marine transgression. He found downcore transitions from deep-water to shallow water foraminiferal assemblages, downcore increases in heavy mineral abundances, and early Holocene $c^{14}$ dates from the shallow box cores 10.4 m penetration). Alternatively, the shelf HM accumulations might have formed from the winnowing of fine grained shelf deposits by offshore currents (Phillips, 1979). Significantly, the first of these two models for offshore placer development implies heavy mineral concentration in beach deposits with subsequent reworking during transgression. It is presently not known whether basal transgressive lag deposits, enriched in beach placer minerals, underly the offshore heavy mineral anomalies reported from the oregon continental shelf. 
The goal of the study presented here is to develop mineralogical and geochemical exploration models for potential titanium- and chromium-rich oxide placers in the continental shelf sands of an active margin. The study objectives are (1) establish the opaque mineral economic grade; (2) constrain the possible models of regional opaque mineral dispersal; (3) evaluate potential mechanisms of origins of marine placers, and (4) decipher the provenance of heavy opaque minerals. These objectives are accomplished by analysis of shelf bulk opaque oxide compositions, by instrumental neutron activation analysis (INAA), electron microprobe, and petrographic grain size statistics. 
CHAPTER II

STUDY AREA

The area under investigation includes the inner- and middle-continental shelf offshore of oregon and northernmost California, extending from $46.25^{\circ}$ to $40.62^{\circ}$ latitude (Figure 1). This study area represents an open coastline distance of $800 \mathrm{~km}$ and a continental shelf area of approximately $4 \mathrm{x}$ $10^{4} \mathrm{~km}^{2}$. The shelf break at $200 \mathrm{~m}$ water depth varies from 80 to $120 \mathrm{~km}$ distance from the coastline (shelf-width). The northern Oregon coastline is relatively straight with the few exceptions of resistant headlands and the local indentations of small bays and estuaries. By comparison the southern part of the coast is dominated by rocky headlands and short beach-fronted embayments. The continental shelf off the coast of oregon is an active and complex sedimentary environment. New sediment is presently being reworked and deposited on the inner portions of the continental shelf while the outer shelf deposits appear to be palimpset (Kulm et al., 1975). Kulm et al. (1975) have classified the unconsolidated sediments deposited on the oregon continental 


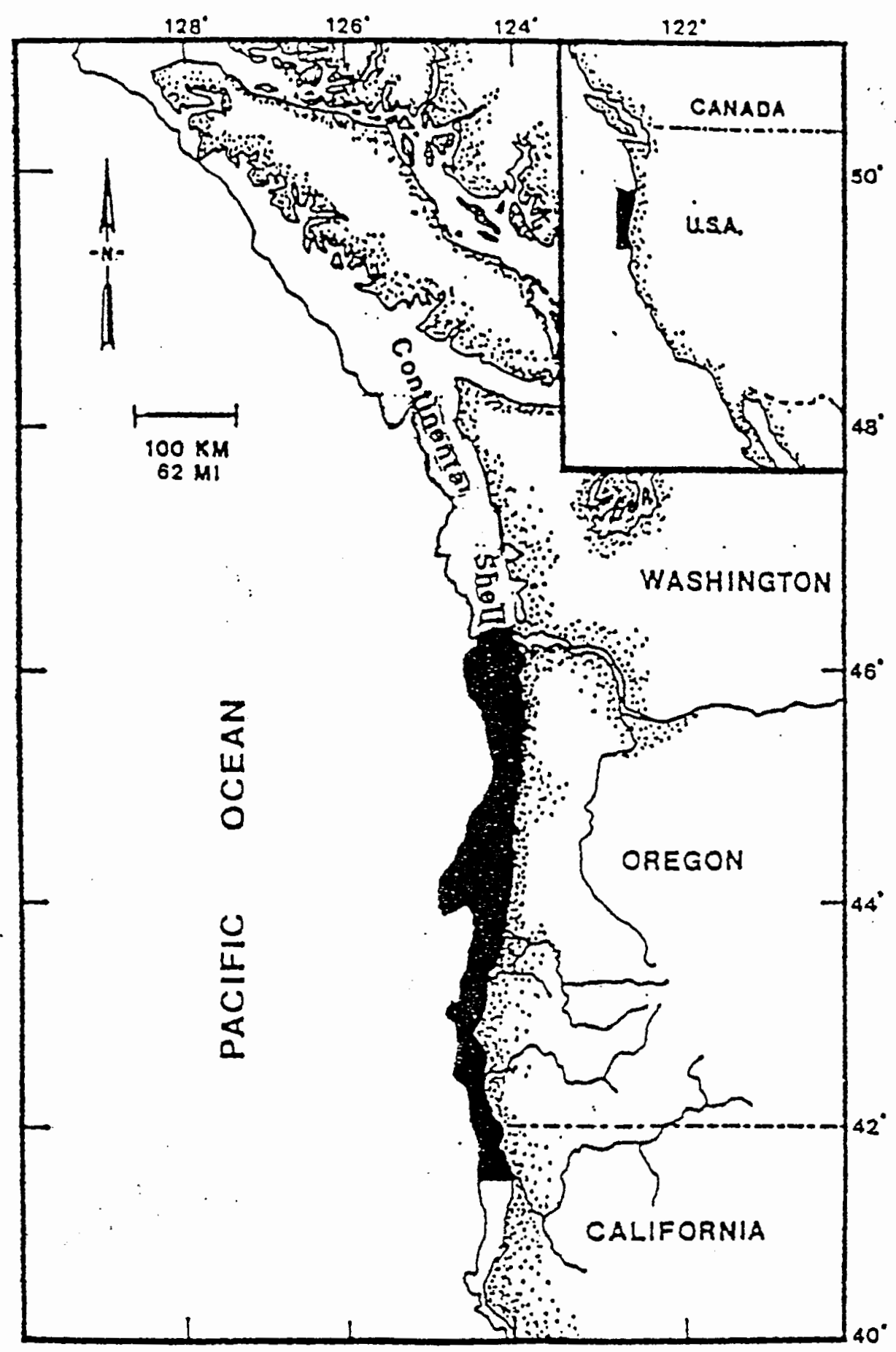

6 
shelf into distinct sedimentary facies: (1) a transgressive sand facies, composed of well sorted fine sand; (2) a modern mud facies consisting of silt and clay; and (3) a mixed facies of sand and mud. The surface shelf currents generally flow northward during the winter months; while bottom currents appear to move northward for most of the year (Gross and Nelson, 1966). Smith and Hopkins (1972) have measured current velocities up to $70 \mathrm{~cm} / \mathrm{sec}$ at $80 \mathrm{~m}$ depths. 
CHAPTER III

REGIONAL GEOLOGY

The tectonic setting of the Pacific coastal states can be divided into two different active plate margins on either side of a triple junction at Cape Mendocino, California. These margins include the southern transform plate boundary of the San Andreas fault system, and the northern subduction boundary where the Gorda and Juan de Fuca plates are being subducted beneath the North American plate in the Cascadia subduction zone (Figure 2; Mooney and Weaver, 1989). Emplacements of oceanic crusts into the Cascadia continental margin occurred between 160 and 40 million years ago, and they produced north-south linear terrains comprising much of the coastal drainages.

The source rock lithology in the southern Cascadia margin is strongly controlled by convergent plate tectonics (as noted above). A variety of accretion, subduction, and obduction events since cretaceous time has yielded a complex assortment of accreted source rock terrains (Figure 3). These terrains include the coast Ranges (northern 


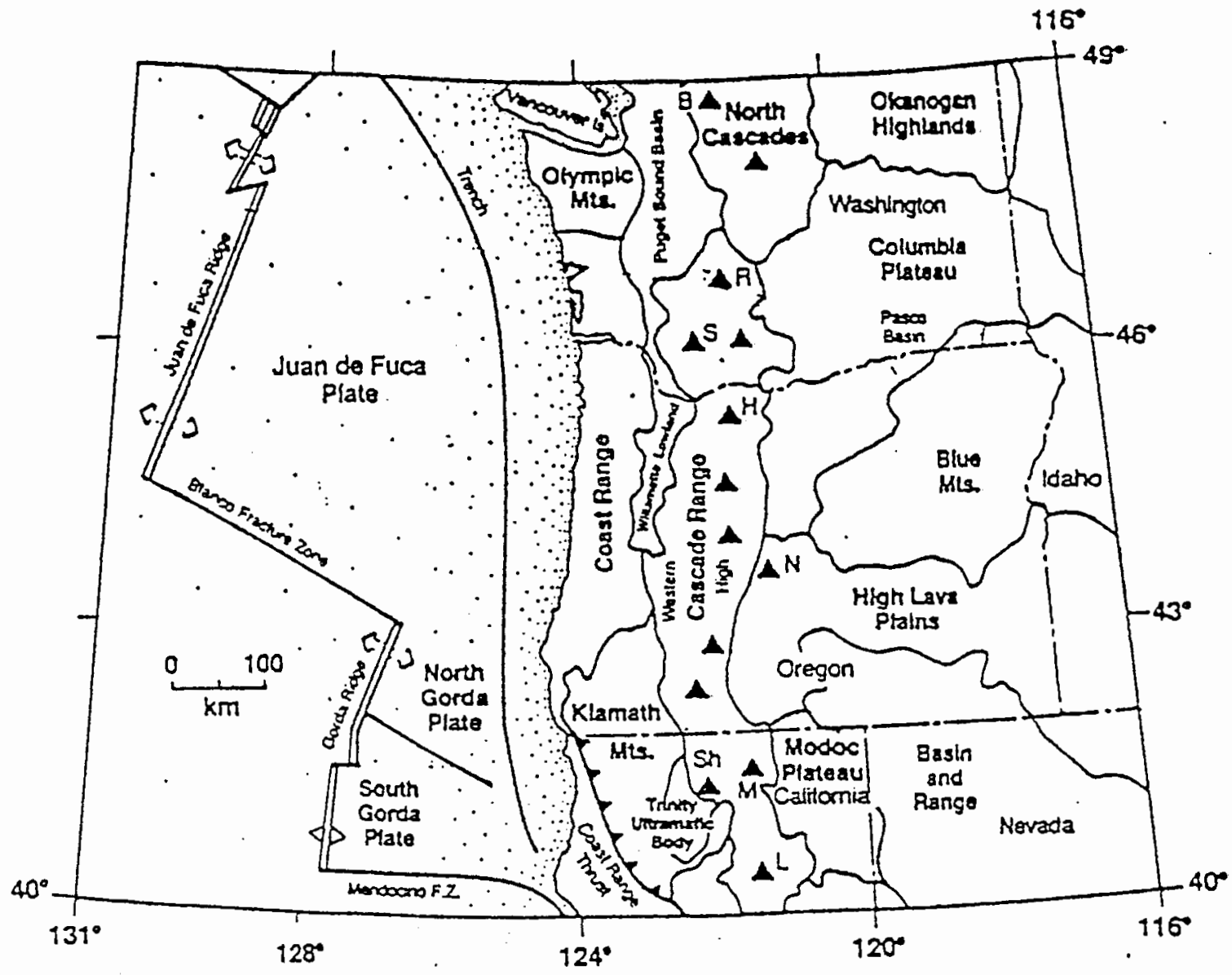

Fiqure 2. General Tectonic Map for the Subduction Regime and Geologic Provinces in the study Area. 

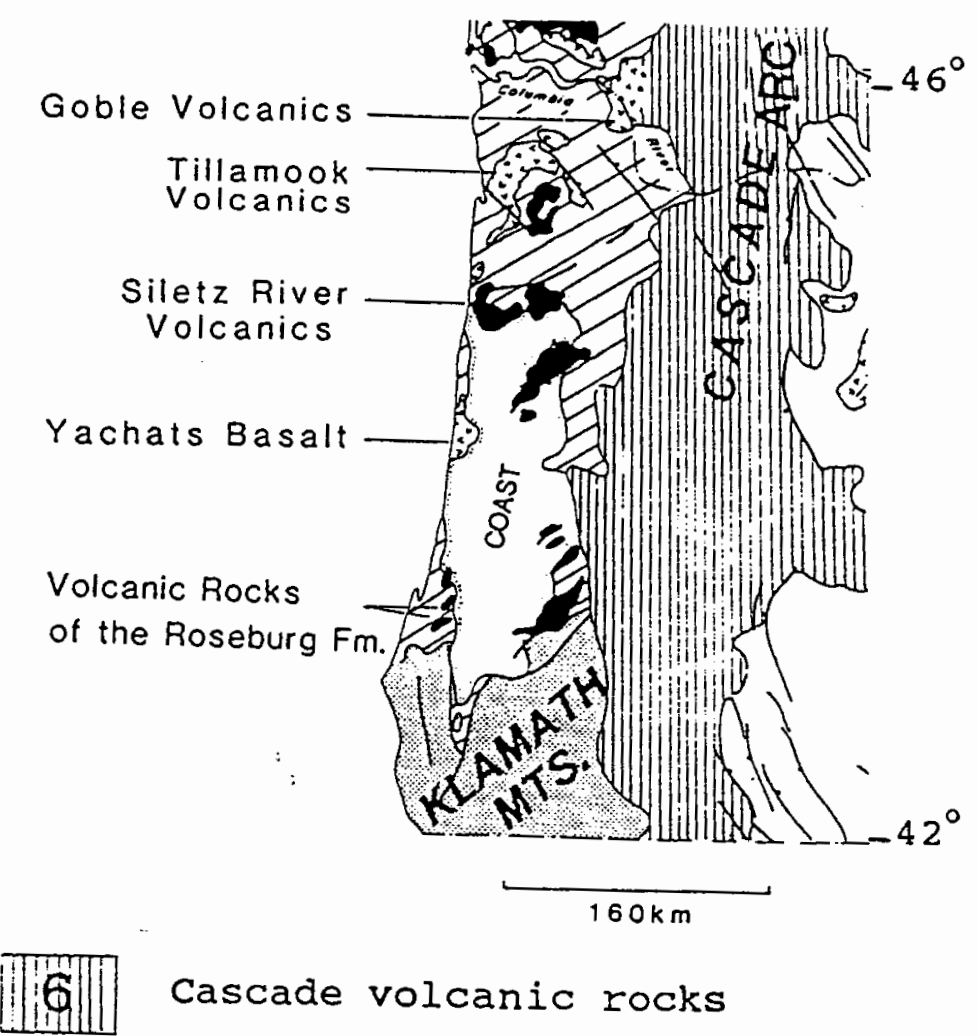

Cascade volcanic rocks

5 Oligocene and Miocene volcanic rocks

Eocene and early oligocene volcanic rocks

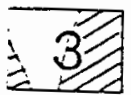
marine Tertiary sedimentary rocks

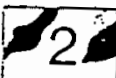

Paleocene to Eocene volcanic rocks

1. pre-Tertiary rocks

Figure 3. Potential Source Rocks of the Continental shelf sediments from Coastal Drainages and Interior Continental Regions of the Pacific Northwest, including the KlamathMountain provenance in southern Oregon and northern California and the northern oregon Coast Ranges (Modified from Wells et al., 1984). 
California, oregon, and Washington), and the Klamath Mountains (southwestern oregon). These 'accreted' terrains are rich in intermediate and mafic rocks, containing the opaque oxide minerals (Ramp, 1961; and Wells et al., 1984). Both river sediments and the recycling of uplifted Pleistocene marine deposits are the likely sources of these minerals to the modern marine placer deposits of the study area (Komar and Clemens, 1986).

KLAMATH MOUNTAINS

The Klamath Mountains were produced from the accretion of Mesozoic oceanic crust and the island arc fragments, emplaced via imbricate east-dipping thrust faults (Irwin, 1981). The Klamath terrain is a complex assortment of metamorphic source rocks containing Paleozoic and Mesozoic metasedimentary, metavolcanic, ultramafic, and sedimentary rocks which have been intruded by granitoid melts (Baldwin, 1964). The areal distribution of lithologies in the Klamath Mountains, define concentric and arcuate belts. These belts include the following lithologic units: the eastern Klamath, central metamorphic, western Paleozoic and Triassic, and western Jurassic (Figure 4). The early paleozoic Trinity (ophiolite) ultramafic sheet overlies Paleozoic and Triassic metamorphic rocks in association with sedimentary and volcanic rocks of fore arc origin (Irvin, 1966). 


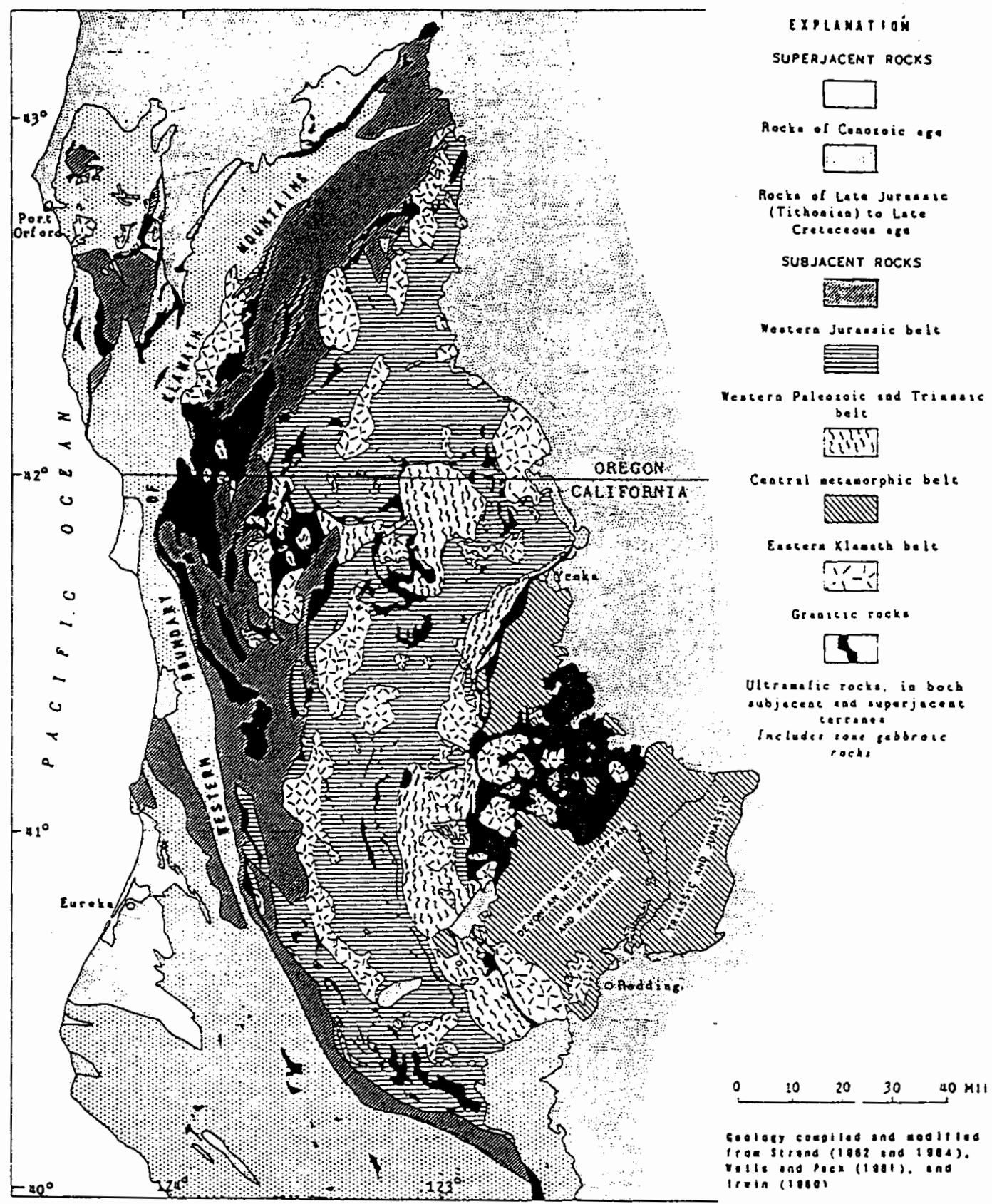

Eigure 4. Geologic Map of Klamath Mountain Province in North western California and Southwestern Oregon (From Irvin, 1966). 
The juxtaposed metamorphic, ultramafics, and granitic intrusions are likely to yield a complex assortment of opaque minerals.

\section{Coast Ranges}

The northern California coast Range contains many coalescing mountains and major structural valleys, yielding high relief and sediments (Spigai, 1971). This coast range consists of two different core complexes, one composed of Franciscan rocks which are a complex Jurassic-Cretaceous eugeosynclinal assemblage, and the other composed of Early cretaceous granitic intrusions and older metamorphic rocks (Page, 1966). These two core complexes are overlain by thick sequences of cenozoic shelf and slope deposits which conceal most of the underlying core complexes.

The oregon coast Range includes both accreted volcanic rocks of probable seamount origin and post-accretion volcanic rocks. The Siletz River (Snavely et al., 1968), and Tillamook Volcanics respectively, are dominantly tholeitic and alkalic basalts, and they might reach thicknesses of $15-20 \mathrm{~km}$. These evolved (differentiated) basement rocks are potentially important sources of ilmenite. Whole rock chemistries of Tillamook Highland Volcanics and Siletz River Volcanics reach up to $4 \%$ and 5$10 \%$ titanium oxide by weight, respectively (Mumford, 1988). 
Cascade Mountain. The Cascade Mountains represent the volcanic arc east of the coast Ranges. These mountains trend north-south for the entire length of the study area and are divided into two physiographic provinces, the Western Cascades and the High Cascades (Figure 5). The Western Cascades comprise lava flows (Eocene to Pliocene in age) of pyroxene andesite, pyroclastic debris, and localized occurrences of nonmarine and shallow-marine sediments. The Western Cascades portray a greater variety and a larger percentage of pyroclastic rocks than the High cascades (Spigai, 1971). The High Cascades are predominantly pyroxene-rich andesites of Pliocene to Recent age.

Columbia River Drainage. The Columbia River Basin encompasses parts of seven states in the northwestern United states and the province of British Columbia in Canada. Major tributaries include the snake, salmon, and willamette Rivers. From the Columbia River headwaters, in the Rocky Mountains, folded and faulted sedimentary, granitic, and coarse grained metamorphic rocks contribute sediment to the river system (Scheidegger et al., 1971). Much of the lower Columbia River drainage is in the columbia River Basalt Province of oregon and eastern Washington. However, Whetten et al. (1969) working on the heavy mineral analysis of lower channel samples of the Columbia River recognized the influence of andesitic detritus formed from the erosion of the Cascade Range. 


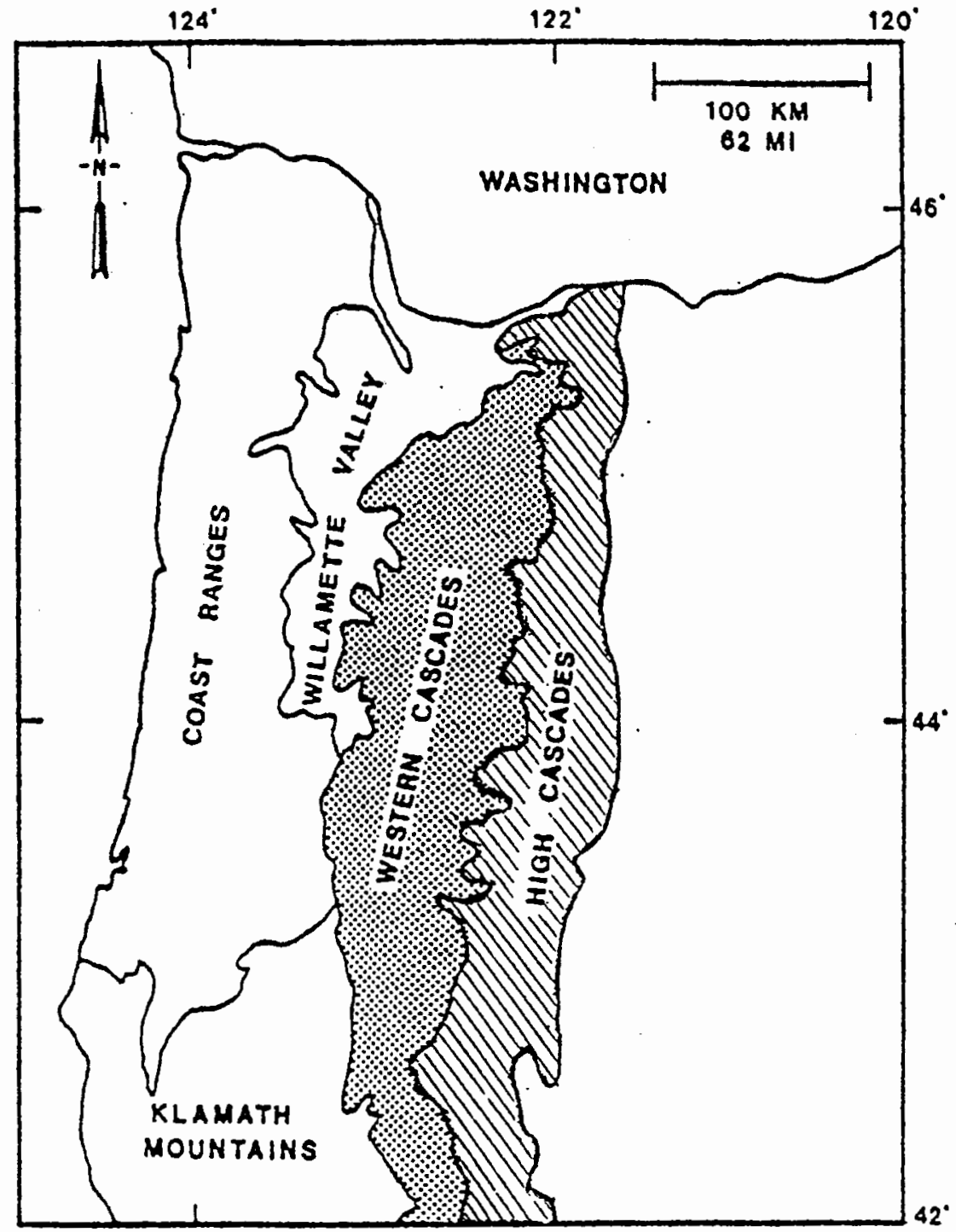

Figure 5. Physiographic Divisions of western oregon. The Cascade volcanic range is shaded (Modified from Peck et al., 1964). 
One of the most comprehensive studies on the mineralogy of sands of the Columbia River estuary was done by white (1967). He found that all of the common heavy minerals present in the Columbia River drainage were also present in the shelf sediments, although orthopyroxene from the Cascade Volcanics appeared to be particularly diagnostic of the Columbia River sediments. Later work by Scheidegger et al. (1971) showed that orthopyroxene rich shelf sands from the Umpqua River (central Oregon) could also be traced to source rocks in the Cascade volcanic arc. 
CHAPTER IV

PREVIOUS WORK ON MARINE PLACERS

Rivers and beaches of southwest oregon and northwest California have historically been mined for placer deposits containing gold and platinum.(Horner, 1918). During mineral shortages of World war II, the coastal terraces of southwest oregon and the Columbia River mouth respectively, were explored for chromite and ilmenite (Griggs, 1945; Kelly, 1947). Onshore marine placers of gold and platinum-group metals are reported to be restricted to southwest oregon and northwest California (Pardee, 1934). Early studies indicated that these deposits are also enriched in chromite, ilmenite, garnet, and zircon (Day and Richards, 1906).

The relationship between continental shelf sediments, potential source areas, and transport mechanisms has been investigated by numerous researchers from several different perspectives. One of the earliest studies on the factors contributing to the concentration of heavy minerals on the beaches of the Pacific Northwest was that of Twenhofel (1946). He proposed that selective removal of light 
minerals by winds coupled with the selective longshore transport may lead to local concentrations of heavy minerals on the southern side of headlands.

stapor (1973) working on marine and coastal dune sands of the Atlantic coast suggested that heavy minerals were not concentrated on the beach face, but were developed offshore and formed as a slug to the beach face. However, this proposed mechanism of placer development contradicts the observation of restricted development of heavy mineral concentrations on beach faces (Everts, 1972).

Slingerland (1977) postulated that the combination of boundary flow turbulence and the ratio of grain size to bed roughness determines the entrainment and the deposition of sand size grains of different density. Bedload transport involves the rolling and saltation of grains which make repeated contacts with the bed. The larger, hydraulically equivalent quartz grains will be rolled away selectively from the relatively smooth bed formed by the finer heavy mineral grains. Sorting leading to heavy mineral deposits can occur only if there are marked differences in critical shear stress (Komar, 1986) between the heavy and light minerals. Later work by Peterson et al. (1986) focused on the distribution of maximum placer development in beach sands (Oregon coast) which occur to the south of headlands. Anamolous.high concentrations of placer minerals typically occur at shoreline inflection points where convergence 
(deceleration) of longshore currents apparently occurs, generally south of major headlands.

The first comprehensive work on the sediment sources and dispersal patterns of shelf sands in the study area was performed by scheidegger et al. (1971). These researchers based their investigation on regional variations of the nonopaque heavy minerals in the shelf sands. This study is particularly interesting, because for the first time, the multivariate vector (factor) analysis approach was used to discriminate the shelf sediments into source end-members. Their work resulted in the delineation of four provenances or source areas. These researchers identified the columbia River Basin, the oregon coast Range, the Klamath Mountains, and Tertiary-Pleistocene terrace deposits along the central Oregon coast as the major sand contributing provenances. Northward longshore drift during the Pleistocene sea level lowstands is suggested as a plausible mechanism for the apparent northward dispersal of Klamath terrain sediments in the continental shelf. Landward transgression of these shelf sands might supply sediment to some beaches on the oregon coast during marine transgression (Komar and clemens, 1986). 
CHAPTER V

METHODS

SAMPLE DESCRIPTION

The samples discussed in this study were sub sampled from collections at oregon State University (Chambers, 1969; Kulm, 1968; Runge, 1966). The samples were chosen on the basis of a wide geographic range, potentially demonstrating distinct sediment sources along the Pacific coast. Figure 6 shows the location of the shelf sample areas in the study area. The bulk sediment samples consist of three classes of minerals:

a. Light: quartz, feldspar, mica

b. Heavy (Magnetic): magnetite, chromite, ilmenite, garnet, epidote, pyroxene, zoisite

c. Heavy (Non-magnetic): zircon, rutile

Opaque oxide minerals reside in the heavy magnetic part of the bulk samples, with restricted specific gravities from 3.8 to 5.2 (Table I). 


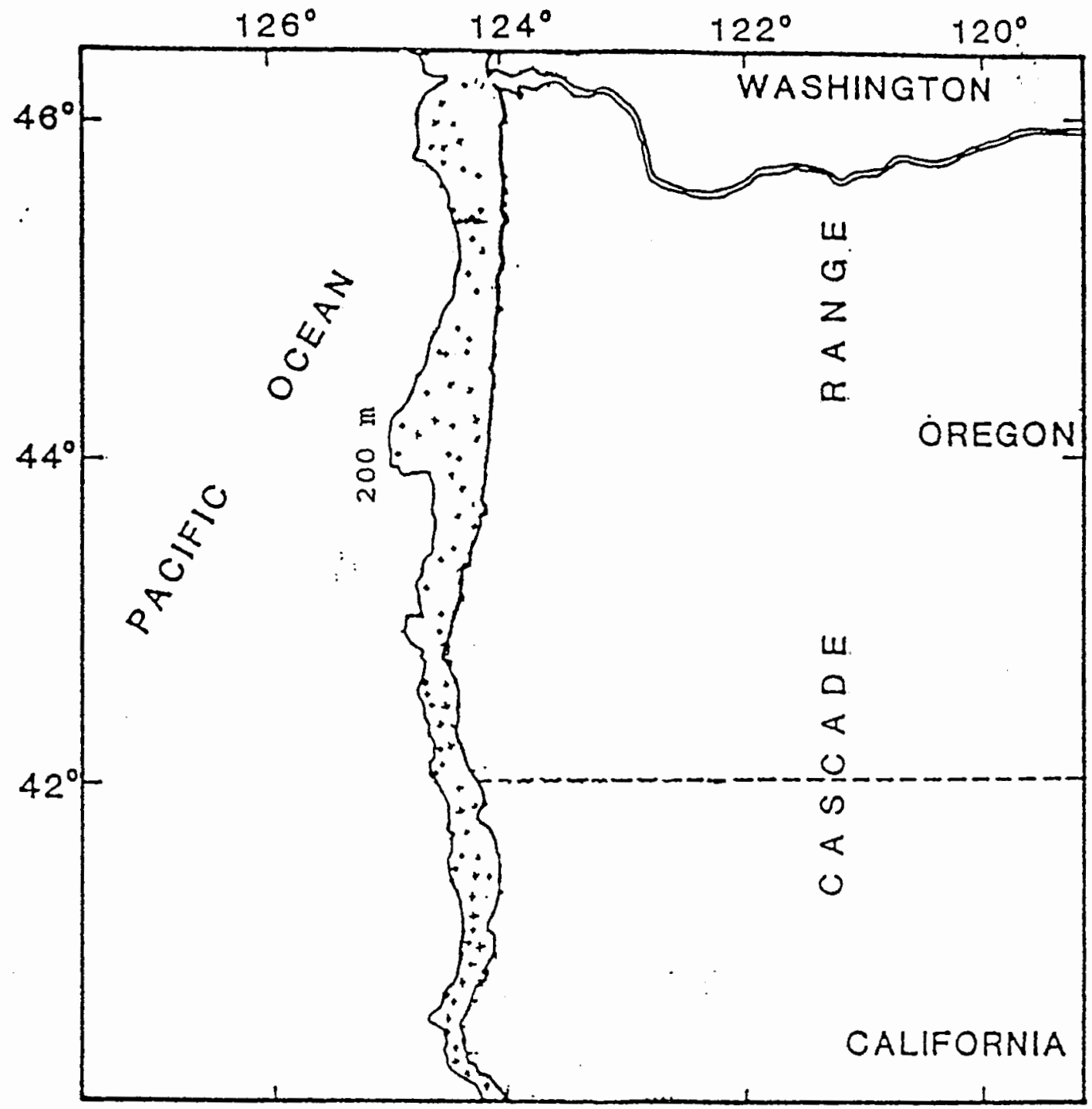

Figure 6. Location Map of Shelf Samples used in INAA and Electron Microprobe analysis. 
TABLE I

HEAVY MINERALS AND METALS IN MARINE PLACERS OF THE PACIFIC NORTHWEST USA

Native Metals Formula

Density Magnetic

Susceptibility

$\left(\mathrm{g} / \mathrm{cm}^{3}\right)$

Gold

$\mathrm{Au}(+\mathrm{Ag})$

$17-19$

Non Susceptible

Platinum

Pt $(+\mathrm{Fe})$

$14-19$

Non Susceptible

Economic

Heavy-Minerals

Magnetite

$$
\mathrm{Fe}_{3} \mathrm{O}_{4}
$$

5.0-5.2 strong

Susceptibility

Ilmenite

(Fe, Ti) $\mathrm{O}_{3}$

4.7-4.8 Moderate

Susceptibility

Chromite

$(\mathrm{Fe}, \mathrm{Mg})(\mathrm{Cr}, \mathrm{Al})_{2} \mathrm{O}_{4}$

3.8-5.2 Moderate

susceptibility

zircon

$\mathrm{ZrSiO}_{4}$

$4 \cdot 6-4.7$ Low

Susceptibility

Garnet $(\mathrm{Fe}, \mathrm{Mg}, \mathrm{Ca}, \mathrm{Al})_{5}\left(\mathrm{SiO}_{4}\right)_{3} 3.6-4.3$ Moderate

Susceptibility 


\section{SAMPLE SEPARATION}

The sample preparation steps used at oregon state University, College of Oceanography are outlined below. All sample processing, instrumental neutron activation analysis, and electron microprobe analysis was performed by Mumford. Raw analytical data was sent to Portland State University for analysis by this author. The separation of the mineral phases is as follows: (1) separation of heavy minerals from light ones at a specific gravity of 3.0 , (2) separation of the heavy minerals into magnetic and non-magnetic minerals, and (3) a separation of the magnetic minerals at a specific gravity > 3.8. Heavy mineral (HM) separation techniques (Figure 7) involved the use of sodium polytungstate with a specific gravity of 3.0 , and tungsten carbide (WC) mixed with the sodium polytungstate to make a colloidal solution of specific gravity (4.2).

Sieving was carried out mainly to separate out rock fragments and other larger particles of silica and quartz which were not of interest for this analysis. The sodium polytungstate separation (specific gravity of 3.0 ) was used to remove the light minerals such as quartz and feldspar in the sample. This step reduced the sample mass, which speeded up the later separation steps. Sample grains were added to $20 \mathrm{ml}$ of sodium polytungstate solution. The sample was centrifuged for about 15 minutes. The grains of greater 
than 3.0 specific gravity settled down in the bottom, while the lighter grains floated on the top.

once the separation was accomplished, liquid nitrogen was used to isolate the light and heavy minerals. Liquid nitrogen was poured into a large beaker and the test tubes containing the separated portions of the sample in the sodium ploytungstate was placed carefully into the liquid nitrogen without disturbing the contents. The bottom part of the solution, where the heavier particles were settled, was frozen completely. The lighter particles, which floated at the top, were then washed off with distilled water into a funnel lined with filter paper. The heavier particles thawed after several minutes and were washed off into a different funnel. The samples in their respective funnels were thoroughly rinsed to wash off the sodium polytungstate. The light minerals for selected river (Sixes River) and shelf sites (10) were grain mounted for petrographic size analysis.

The heavy mineral fractions of all samples underwent additional separation steps as outlined below (Figure 7). The main object of this separation process was to retrieve the heavy opaque magnetic fraction of the sample (magnetic minerals such as magnetite, chromite, and ilmenite). A hand magnet was used first for the removal of strongly magnetic substances (magnetite). This method was efficient and it averted magnetite clogging in the Frantz separator. In the Frantz isodynamic magnetic separator, a series of current 


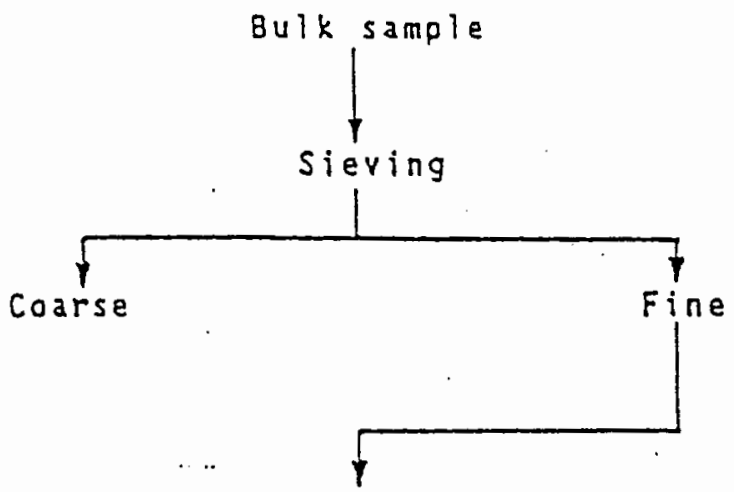

Na polytungstate separation at specific gravity $=3.0$
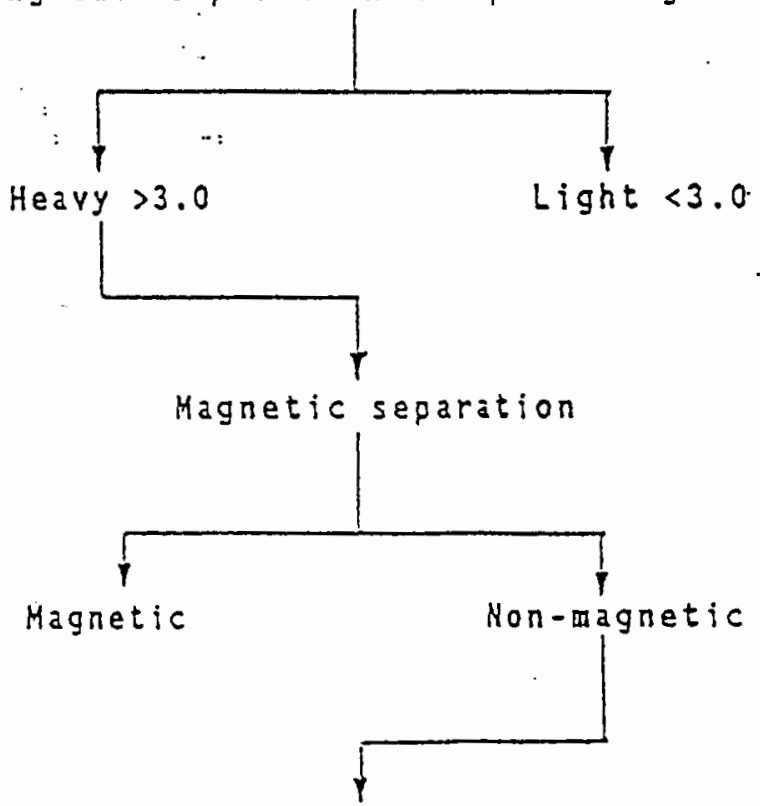

Na polytungstate $+H C$ separation

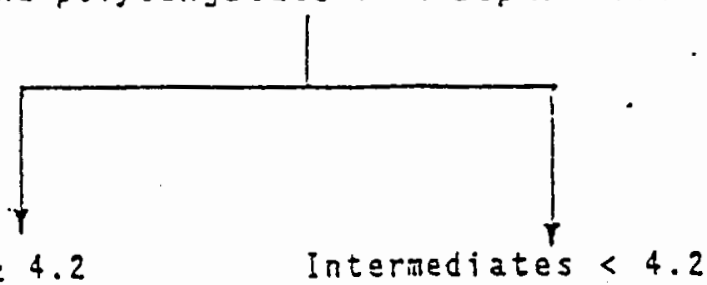

Figure 7. Sample separation scheme:

Preliminary sieving (250 $\mathrm{mm}$ ) was used to screen off the rock fragments and multimineralic aggregates. 
settings were reqiured to separate out the heavy magnetic minerals. Initially the current was set at $0.1 \mathrm{~A}$ and the tilt angle was set at $20^{\circ}$. The sample was run through the separator once to remove the most magnetically susceptible particles. Next the current was increased to $0.4 \mathrm{~A}$ and the non-magnetic portion of the sample was run through at least three times again to remove the ilmenite, chromite and their associated silicate contaminants. At each setting the portion of the sample retained as non-magnetic was run through the Frantz separator to clean the sample of magnetic minerals. The magnetic and the non-magnetic portions were weighed, and the masses were registered.

The mineral separation experiments utilizing magneticsusceptibilty and density have clearly demonstrated, an inability to separate the pure opaque phases (chromite, ilmenite, and magnetite) due to the presence of inclusions and exsolution lamellae of different opaque minerals within the mineral grains. The inclusions might also result in some cross contamination of trace elements ( $\mathrm{Ca}, \mathrm{Al}, \mathrm{Mn}, \mathrm{Mg}$, $\mathrm{Co}, \mathrm{SC}$, and $\mathrm{V}$ ) in the mineral separates. Minor intergrowths of ilmenite/magnetite, chromite/magnetite, and incorporation of pyroxene and amphibole make geochemically pure mineral separations unattainable. 


\section{SAMPLE ENCAPSULATION}

Encapsulation for irradiation was the final step in sample preparation for the neutron activation analysis (INAA). After the opaques (magnetite, chromite and ilmenite) had been separated, they were triply encapsulated in polyethylene polyvials for the purpose of safegaurding against the accidental spilling from the breakage of polyvials after irradiation. Since the mass of the sample was not to exceed $160 \mathrm{mg}$ (this upper limit for mass is determined on the basis of activity produced in the sample), 2/27 dram polyvials were appropriate for the inner sample encapsulation.

Sample Mounting and Polishing for Microprobe work

To establish the grain size distributions of the opaque oxide minerals (chromite, ilmenite, and magnetite) in river sources, composite sampling was done for the Sixes River in southern Oregon. Opaque mineral grains (at least 100 per sample) were mounted in epoxy and polished for energy dispersive $x$-ray analysis (electron microprobe) of relative abundance of ilmenite, chromite, and magnetite grains for different grain size distributions. 


\section{INSTRUMENTAL NEUTRON ACTIVATION ANALYSIS (INAA)}

Neutron activation analysis is based on the identification of elements present in a sample after it has been irradiated by a neutron source, such as a nuclear reactor. The energy of the emitted gamma ray and the area of the associated photopeak are used to determine the amount of that particular element in the sample (Knoll, 1979). The potential use of neutron activation for chemical analysis was realized as early as 1936 (Hevesy and Levi). With advances in technology including more efficient and higher resolution detectors, INAA has become a powerful method for trace element analysis of geologic samples.

\section{INAA Parameters}

In this project the comparative method for sequential neutron activation analysis was used to determine the elemental concentrations of major and trace elements in bulk oxide splits (chromite, magnetite and ilmenite). The standards used for the Rabbit Analyses (OSU nuclear reactor was used; Mumford, 1991; personal communication) include Spex Oxides $\left(\mathrm{Al}_{2} \mathrm{O}_{3}, \mathrm{TiO}_{2}\right.$ and $\left.\mathrm{CaCO}_{3}\right)$ liquid $\mathrm{V}$ and $\mathrm{Mn}$ standards, NBS STDS (SRM-1571-leaves,-1632-coal and -688silicate rock) and USGS STD BCR-1. Standards used for the long-lived Analyses include, in-house liquid REE STD, USGS BCR-1, USGS DTS-1 and NBS STD SRM 1633-Fly Ash. These 
standards were chosen because they contain a wide variety of elements expected to be present in the opaque oxides.

Neutron Flux. The samples and the standards are generally irradiated under identical neutron flux conditions for INAA. In this project the oregon state University (OSU) nuclear reactor was used for irradiating the samples. For both long and short irradiations the reactor was operated at a power level of $1 \mathrm{MW}$, which gave a flux of $9 \times 10^{12} \mathrm{n} / \mathrm{cm}^{2}-\mathrm{s}$ in the pneumatic transfer system, and a flux level of $3 \mathrm{x}$ $10^{12} \mathrm{n} / \mathrm{cm}^{2}-\mathrm{s}$ at the rotating rack. The mass of the samples combined with this flux level gave a count rate which produced satisfactory statistics for most of the nuclides of interest.

Irradiation, decay and counting times. Irradiation, decay and counting times are important factors in sequential NAA (Laul, 1979). Sequential neutron activation analysis follows the procedure of counting the short-lived radionuclides first, followed by a decay period and subsequent counting of the longer lived radionuclides.

For short irradiations the samples were irradiated in the pneumatic transfer facility for 2 minutes and then allowed to decay for 10 minutes (an average time of 10 minutes was required to transfer the samples to clean polyvials and transport them to the counting room). The short-lived radionuclides (representative of the elements Ti, Al, V, Mg and $\mathrm{Ca}$ ) which have a half life in the range of 
2-10 minutes were counted first. The first counting time was of 5 minutes duration. The samples and the standards were then allowed to decay for 3 hours in order to reduce the activity level of the short-lived radionuclides. The decay of these short-lived nuclides reduced the compton continuum for the photopeaks of the longer-lived radionuclides. These samples were then counted for 10 minutes for the elements $\mathrm{Na}, \mathrm{K}$ and $\mathrm{Mn}$.

For the long irradiations, the samples and the standards were irradiated for 7 hours in the rotating rack (Lazy Susan). The samples were allowed to decay for 7 days which was sufficient for the short-lived radionuclides to decay completely. The samples were then counted for 3 hours for the elements $\mathrm{Fe}$, Co, $\mathrm{As}, \mathrm{Sb}, \mathrm{Rb}, \mathrm{Ba}, \mathrm{La}, \mathrm{Nd}, \mathrm{Sm}, \mathrm{Yb}$ and Lu. The radionuclides associated with these elements were allowed to decay for 30 days and then the radionuclides associated with the elements Sc, $\mathrm{Cr}, \mathrm{Co}, \mathrm{Zn}, \mathrm{Sr}, \mathrm{Sb}, \mathrm{Cs}, \mathrm{Ce}$, $\mathrm{Eu}, \mathrm{Tb}, \mathrm{Zr}, \mathrm{Hf}$, and Ta were counted for 6 hours.

Table II gives properties of the radioisotopes measured along with some other parameters of this analysis (Laul, 1979).

\section{ELECTRON MICROPROBE}

In order to establish the elemental compositions and size distributions of the specific mineral phases (chromite, ilmenite and magnetite), splits of opaque minerals from 
TABLE II

RADIONUCLIDES AND INAA PARAMETERS

Element Isotope Half life gamma ray energy

Group A

$\mathrm{Ti} \quad 51 \mathrm{Ti} \quad \mathrm{min}$

Mg

$\mathrm{V}$

AI

$\mathrm{Ca}$

Mn

$\mathrm{Na}$

K

${ }^{27} \mathrm{Mg}$

${ }^{52} \mathrm{~V}$

${ }^{28} \mathrm{Al}$

${ }^{49} \mathrm{Ca}$

$9.46 \mathrm{~min}$

$3.75 \mathrm{~min}$

$2.32 \mathrm{~min}$

$8.80 \mathrm{~min}$

Group B

${ }^{56} \mathrm{Mn}$

$2.58 \mathrm{hr}$

$15.0 \mathrm{hr}$

$12.4 \mathrm{hr}$

Group C

$\mathrm{Fe}$

${ }^{59} \mathrm{Fe}$

co

Ia

$$
\begin{array}{r}
{ }^{58} \mathrm{Ni}\left({ }^{58} \mathrm{Co}\right) \\
{ }^{140} \mathrm{La}
\end{array}
$$

71.3 day

$40.2 \mathrm{hr}$

816,1597

(keV)

Sm

$\mathrm{Yb}$

Lu

$46.8 \mathrm{hr}$

103

4.21 day

283,396

6.74 day

208 
TABLE II

RADIONUCLIDES AND INAA PARAMETERS

(continued)

Element Isotope Half life gamma ray energy

Group D

$\begin{array}{lrrlr}\mathrm{Sc} & { }^{46} \mathrm{SC} & 83.85 & \text { day } & 889,112 \\ \mathrm{Cr} & { }^{51} \mathrm{Cr} & 27.8 & \text { day } & 320 \\ \mathrm{Sb} & { }^{124} \mathrm{Sb} & 60.3 \text { day } & 564,169 \\ \mathrm{Ce} & { }^{141} \mathrm{Ce} & 32.5 \text { day } & 146 \\ \mathrm{Eu} & { }^{152} \mathrm{Eu} & 12.7 & \text { day } & 122,1408 \\ \mathrm{Hf} & { }^{181} \mathrm{Hf} & 42.5 & \text { day } & 482\end{array}$


selected river samples (23) were mounted in epoxy and polished for analysis by electron microprobe. Microprobe analyses of individual mineral grains provides accurate elemental compositions of specific mineral phases. A Cameca Sx50 microprobe and scanning electron microscope system (Oregon State University) was used for the analysis. Specimen counting times ranged from 10 seconds (major and minor elements) to 100 seconds (trace and rare earthelements), with a beam (2-5 micron width) generated at $15 \mathrm{kV}$ and $20 \mathrm{na}$. Beam positions within specimen grains were located (under reflected light) to avoid (1) multimineralic phase boundaries, (2) inclusions, and (3) cracks or dissolution embayments. At least 100 randomly picked opaque grains per sample were analyzed for elemental composition (Mumford, 1991; personal communication).

Preliminary microprobe analysis of the opaque oxide splits based on density and magnetic susceptibility experiments demonstrated minor mineral cross contamination (Peterson and Binney, 1988). The contamination occurs due to the presence of magnetite and ilmenite intergrowths, rare magnetite rims around chromite grains, and magnetite inclusions in chromite grains (Peterson, 1991; personal communication) . 
CHAPTER VI

RESULTS

INAA OF CONTINENTAL SHELF DEPOSITS

Elemental analysis of bulk opaque mineral fractions was performed on surface sediments from the continental shelf off oregon and northwest California, in order to compare the relative abundances of iron, titanium, and chromium, and to establish associated trace elements in the opaque mineral fractions. Elemental analysis of the opaque mineral fractions was performed by Instrumental Neutron Activation Analysis (INAA). Some 87 surface and nearsurface samples (SI - OR-16) were selected from existing grab samples, short box cores $(<45 \mathrm{~cm})$, and short piston or gravity cores ( $<60 \mathrm{~cm}$; see the Appendix A for cross reference of sample numbers) from oregon state University core archives (Mumford, 1991; personal communication). The sediment samples were selected based on the following criteria: (1) geographical distribution relative to known coastal placer deposits containing economic minerals, 
landward fluvial sources of economic minerals, and (3) high heavy-mineral content of shelf deposits. Samples analyzed in this study range in water depths from 17 to about 200 meters on the shelf.

A full suite of 21 elements (Appendix A) was run on 87 samples. Figure 8 and 9 show the variation of $\mathrm{Cr}$ and $\mathrm{Ti}$ respectively as a function of latitude in the bulk opaque mineral fractions. High values of $\mathrm{Ti}$ (exceeding $20 \mathrm{wt} \%$ ) are found in the northern shelf between latitudes $42.5^{\circ}$ and $46.0^{\circ}$. In contrast, the elevated $\mathrm{Cr}$ values $(4-6 \mathrm{wt} \%)$ are restricted to the southern shelf at latitudes $40.5^{\circ}$ and $42.5^{\circ}$. These relative trends of $\mathrm{Ti}$ and $\mathrm{Cr}$ abundance in shelf bulk opaque mineral splits are very similar to the results found in onshore river and beach deposits (Peterson et al., 1988). Across-shelf transects (Figures 10-14) of $\mathrm{Cr}$ and $\mathrm{Ti}$ from the opaque fraction of shelf sands generally reflect the regional variability associated with the onshore source rocks. However, the plots of samples from 44-45, and 45-46 degrees latitude (Figures 13 and 14) do show slight decreases in titanium with increased distance offshore. Whereas, elemental chromium values slightly increase towards the offshore.

The latitudinal distribution of high chromium abundance in shelf sands corresponds to source rocks associated with the Klamath Mountains (Figure 8). In contrast, high titanium abundance is restricted to the shelf 


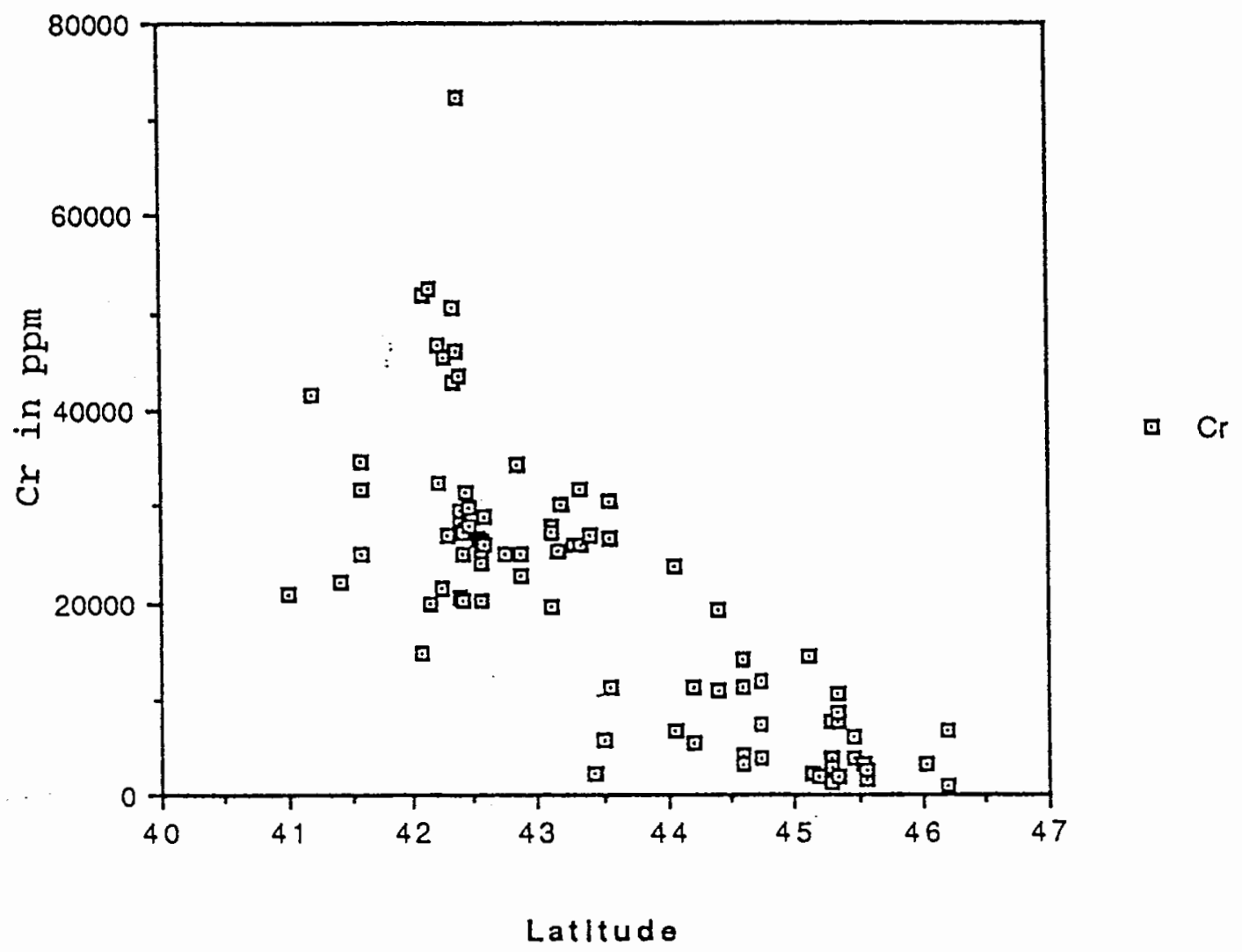

Figure 8. Plot of the Major Element Chromium of Bulk Opaque Mineral Separates from the continental Shelf as a Function of Latitude. 


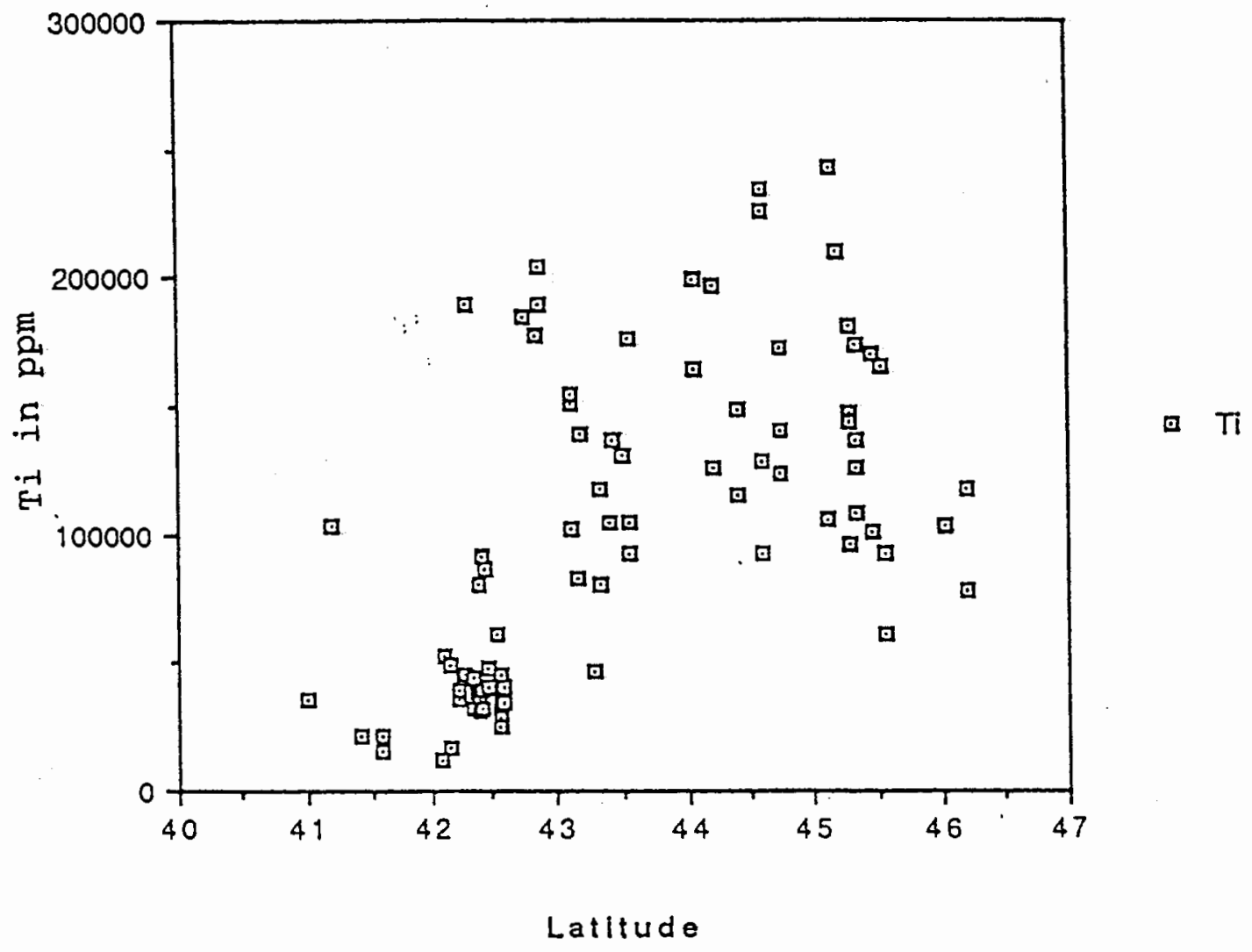

Fiqure 9. Plot of the Major Element Titanium of Opaque Mineral separates from the Continental Shelf as a Function of Degrees Latitude. 


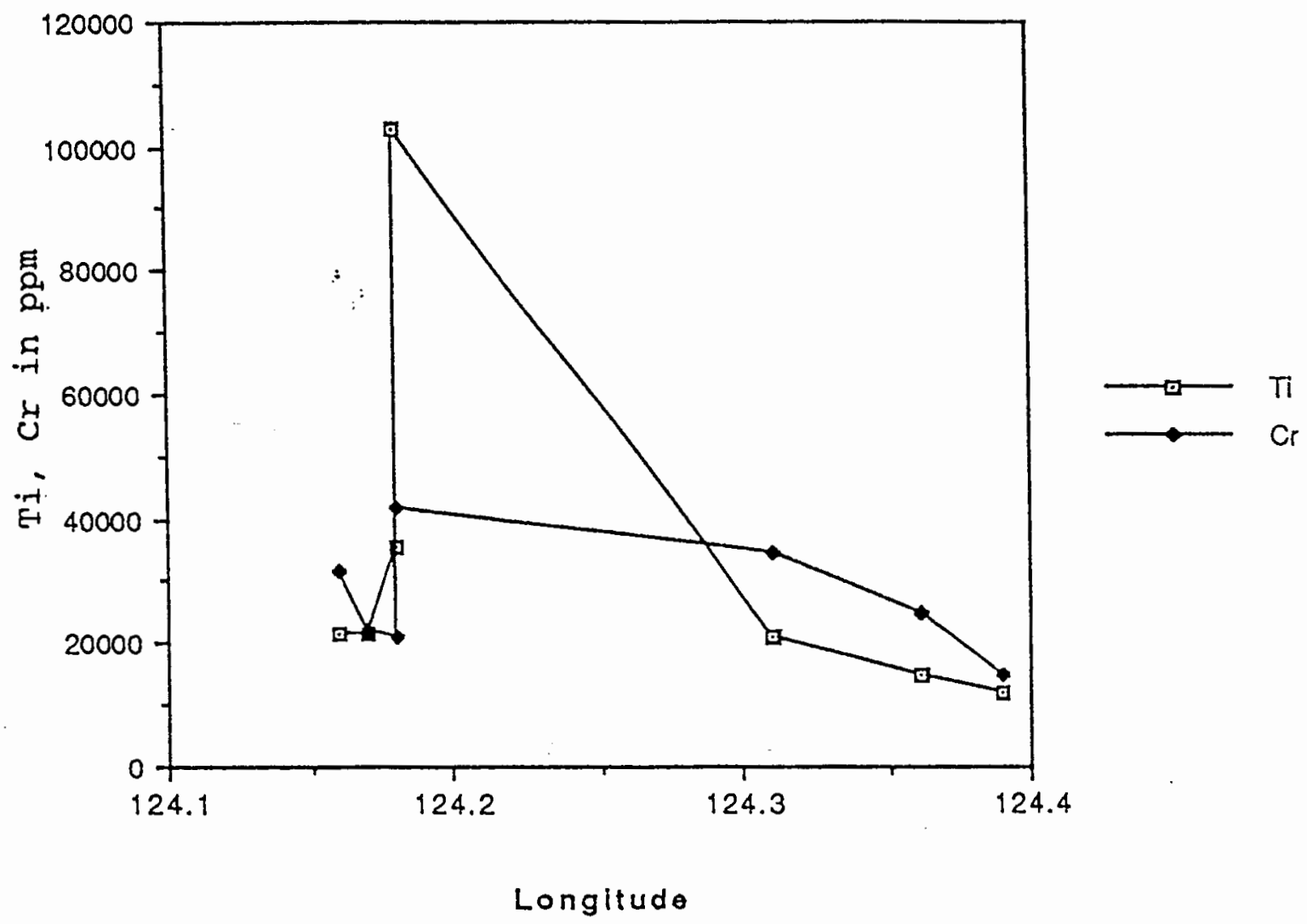

Figure 10. Across-shelf Transect of Chromium and Titanium Elemental Abundance for the Samples from 41-42 Degrees Latitude. 


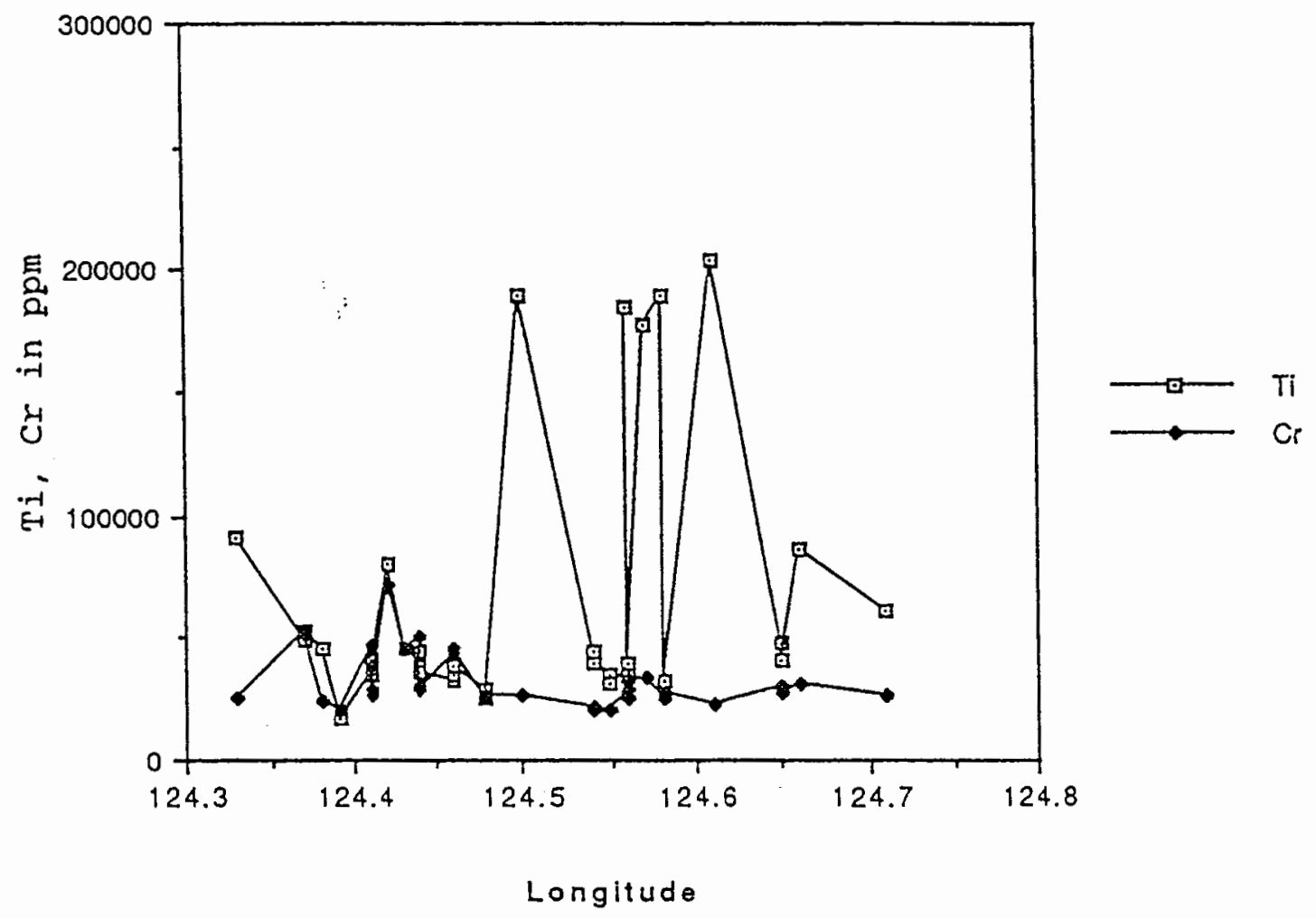

Figure 11. Across-shelf Transect of Chromium and Titanium Elemental Abundance for the Samples from 42-43 Degrees Latitude. 


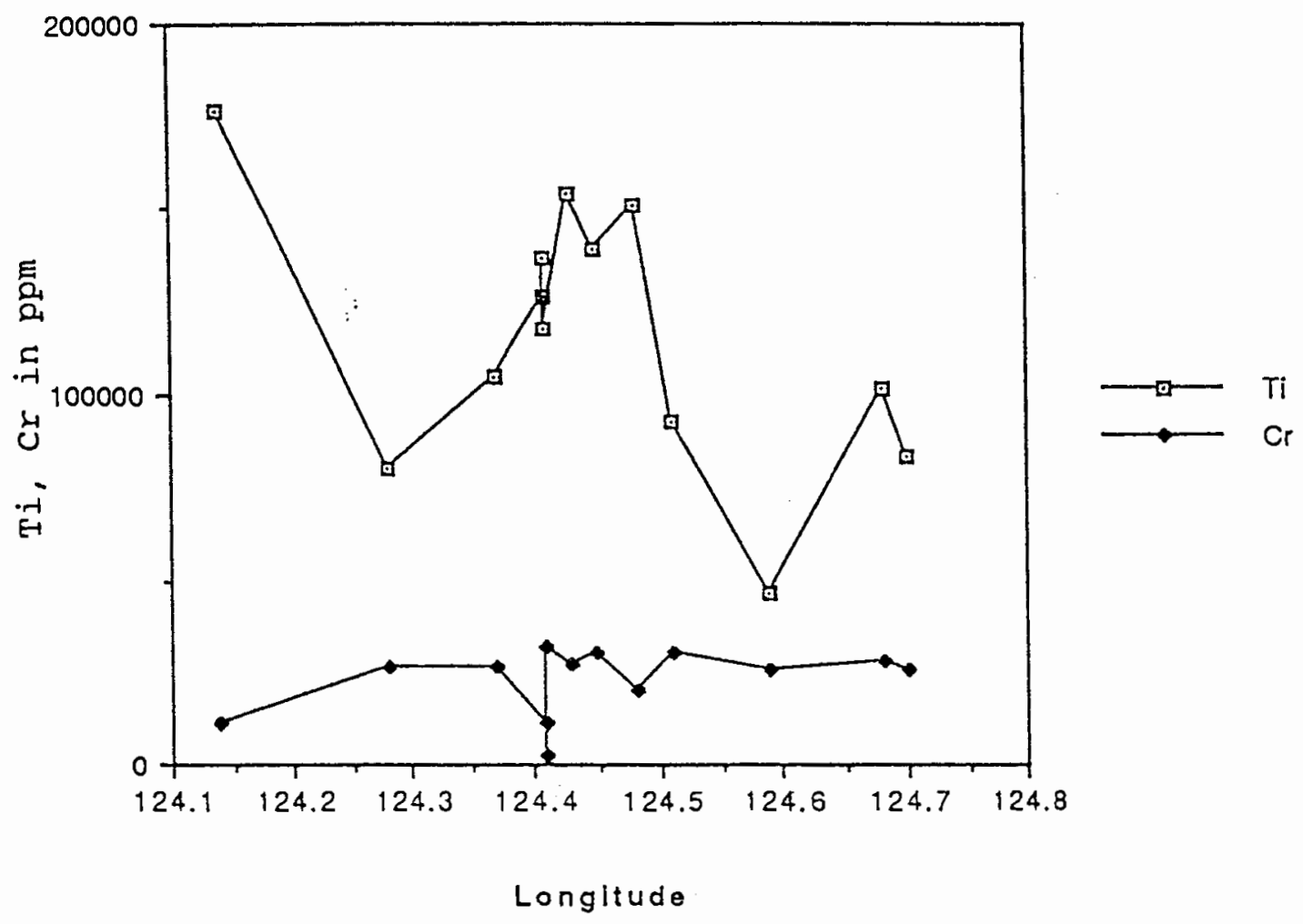

Figure 12. Across-shelf Transect of Chromium and Titanium Elemental Abundance for the Samples from 43-44 Degrees Latitude. 


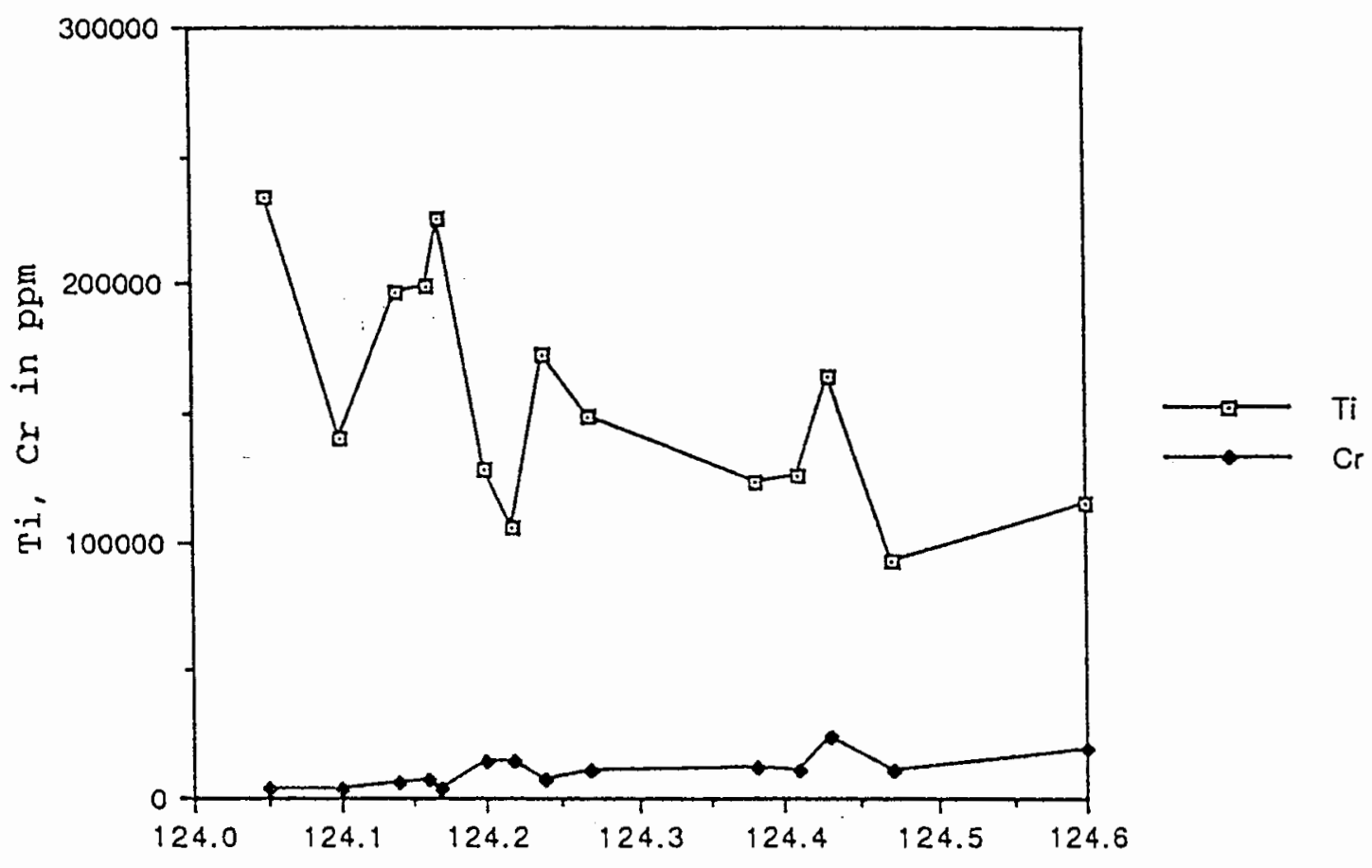

Longltude

Figure 13. Across-shelf Transect of Chromium and Titanium Elemental Abundance for the Samples from 44-45 Degrees Latitude. 


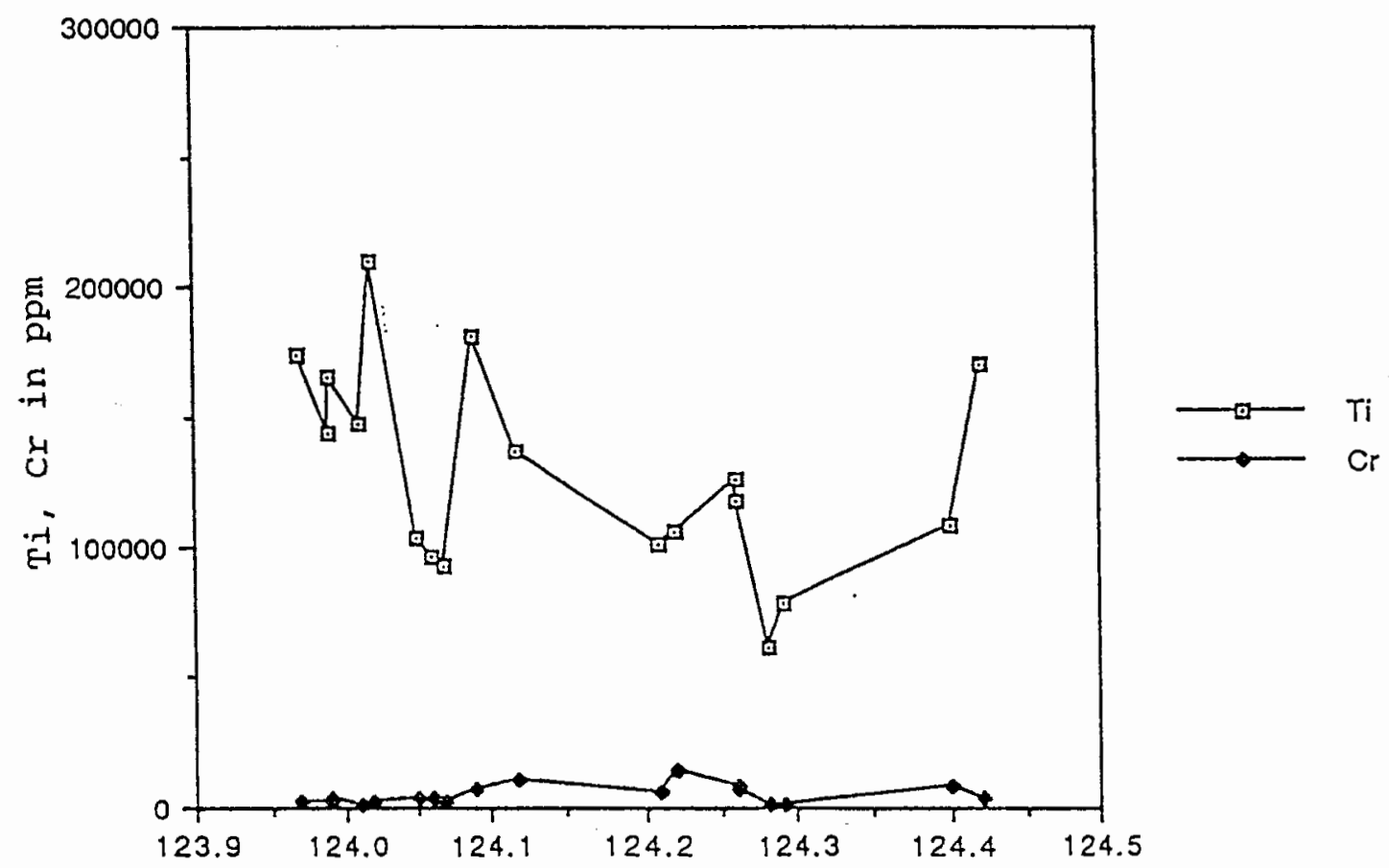

Longltude

Figure 14. Across-shelf Transect of Chromium and Titanium Elemental Abundance for the Samples from 45-46 Degrees Latitude. 
sediments derived from drainages of oregon coast Range (Figure 9). Maximum values of titanium (exceeding 20 wt\%) are found in the northern shelf between latitudes $43^{\circ}$ and $45.5^{\circ}$. Figure 11 indicates the titanium and chromium variability might also be due to crossing of north-south (along-shelf) boundary rather than a across-shelf dispersal phenomena. The shelf opaque mineral geochemistry generally demonstrates an across-shelf mineral dispersal pattern, with the possible exception of the most seaward samples on the shelf (Figure 12 and 13).

Total iron abundances are shown in Figure 15 for the shelf samples. Iron in the opaque mineral separates demonstrates significant local variability (20-51 wt\%) over length scales of $10-100 \mathrm{~km}$. It does not define any consistent regional trend. Maximum iron values (40-51 wt\%) occur at about $42.5^{\circ}$ and $44.5^{\circ}$ latitude. In contrast to the iron, both chromium and titanium indicate significant regional changes in element abundance along the shelf. The contrasting distributions of chromium-rich oxides (south of $43^{\circ}$ ) and titanium-rich oxides (north of $43^{\circ}$ ) delineate distinctly different source rocks from the Klamath Mountains (south) and the coast Range (north).

Linear regressions of specific major and trace element pairs can be used to establish trace element partitioning into the dominant opaque oxide phases. From the microprobe data discussed below, it is known that chromium is present 


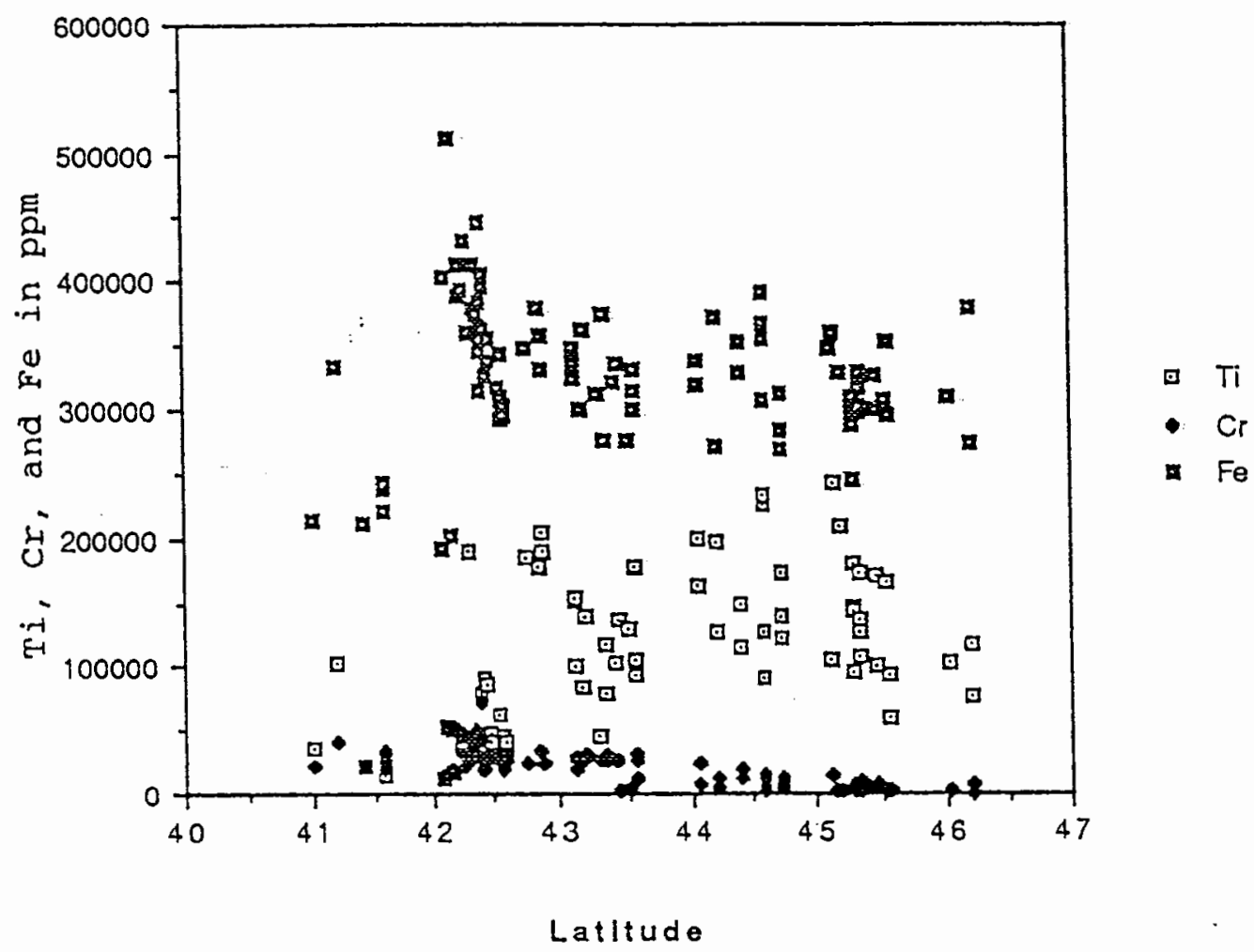

Figure 15. Plots of the Major Element (Fe, $\mathrm{Cr}$, and $\mathrm{Ti}$ ) Abundances as a Function of Latitude are shown for the opaque mineral separates from the shelf of placers. 
exclusively in the chromite mineral grains. A high positive correlation between cobalt and chromium ( $\mathrm{Co}-\mathrm{Cr}$, correlation coefficient $r=0.92 ;$ Figure 16) indicates efficient trace element (cobalt) partitioning into chromite. However, a lack of high correlation between nickel and chromium suggests that $\mathrm{Ni}$ is not entirely partitioned into chromite (see correlation matrix Table IV). The major and trace elements partitioned into chromite ( $\mathrm{Mg}, \mathrm{Al}, \mathrm{Co}$, and $\mathrm{Ni}$ ) are characterized by +2 or +3 valence states and intermediate to large ionic-radii (0.2-0.4 in octahedral coordination). The high positive correlations between trace (Hf, Sc) and titanium (Hf-Ti, $r=0.90 ;$ Figure 17 and Sc-Ti, $r=0.70 ;$ Figure 18) indicate that these trace elements are partitioned into ilmenite, and possibly to some extent, into titaniferous magnetite. The trace elements (Hf, Sc, Ta) partitioned into ilmenite, are characterized by their $+3,+4$ valence states and small ionic radii. The elements $\mathrm{Mg}, \mathrm{Ca}$ and $\mathrm{Mn}$, which are not selectively partitioned into ilmenite, are distinguished by their +2 valence states and large ionic radii. Figure 19 shows that the only trace element correlated with the iron, is vanadium ( $V-F e, r=0.74)$. Presumably, the vanadium is largely partitioned into magnetite, as it is not correlated with either the chromium or titanium metals in chromite and ilmenite respectively. The relatively moderate correlation between vanadium and iron, likely results from the distribution of some of the 


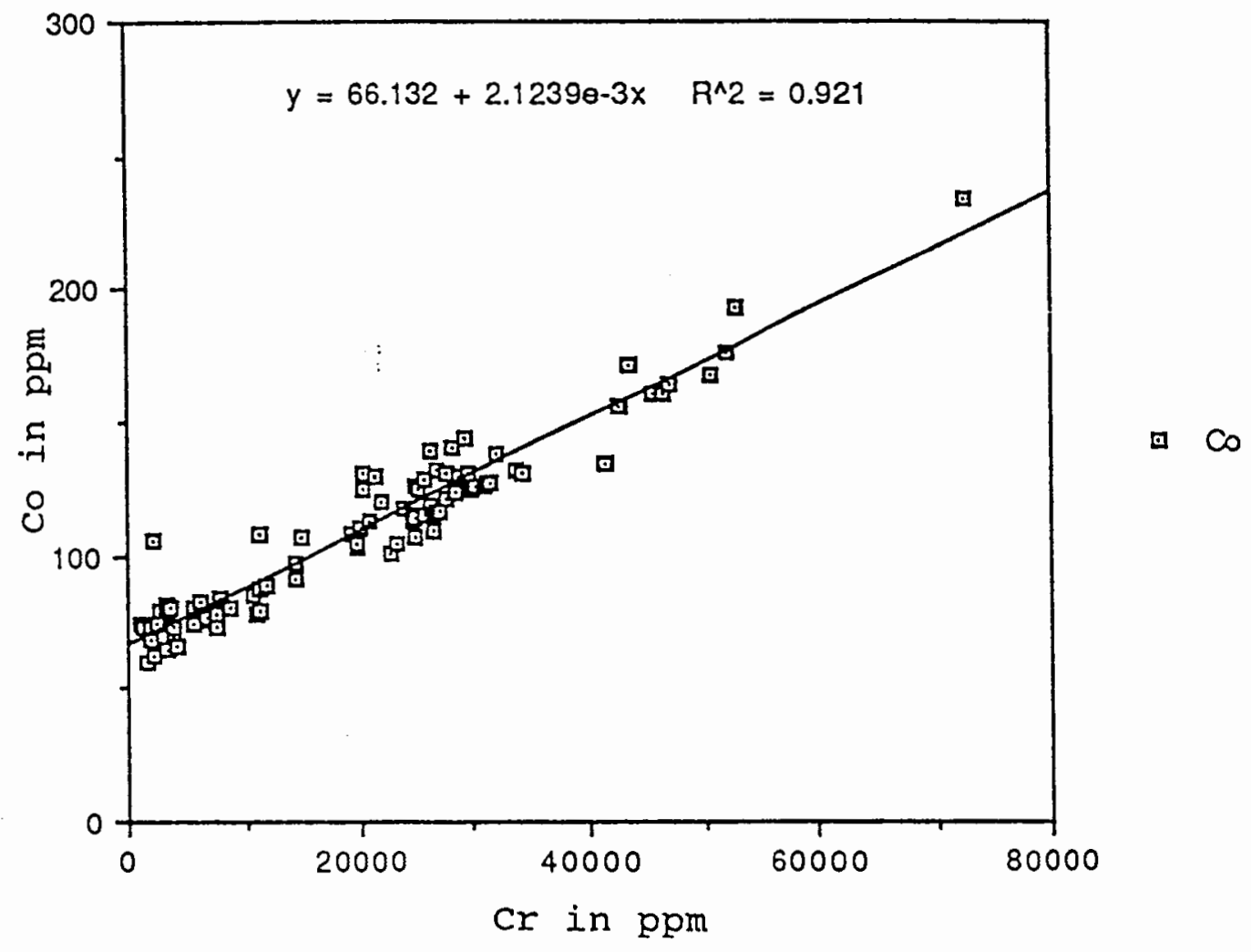

Figure 16. Plots of Chromium and cobalt Elemental Values of opaque Mineral oxides from the continental Shelf. 
TABLE III

ELEMENTAL CORRELATION COEFFICIENTS FOR OPAQUE MINERAL FRACTION OF RIVER, BEACH, AND SHELF SANDS IN OREGON AND NORTHERN CALIFORNIA, 40.5-46.5 DEGREES LATITUDE

$\begin{array}{cccccccc} & 1 & 2 & 3 & 4 & 5 & 6 & 7 \\ 1 & 1.000 & 0.374 & 0.210 & 0.631 & 0.054 & -0.278 & -0.083 \\ 2 & 0.374 & 1.000 & 0.580 & 0.780 & -0.269 & -0.679 & -0.100 \\ 3 & 0.210 & 0.580 & 1.000 & 0.457 & -0.550 & -0.791 & -0.009 \\ 4 & 0.631 & 0.780 & 0.457 & 1.000 & -0.071 & -0.515 & -0.122 \\ 5 & 0.054 & -0.269 & -0.550 & -0.071 & 1.000 & 0.793 & -0.159 \\ 6 & -0.278 & -0.679 & -0.791 & -0.515 & 0.793 & 1.000 & -0.078 \\ 7 & -0.083 & -0.100 & -0.009 & -0.122 & -0.159 & -0.078 & 1.000 \\ 8 & -0.438 & 0.119 & 0.654 & -0.140 & -0.618 & -0.513 & 0.036 \\ 9 & -0.376 & -0.502 & -0.335 & -0.443 & 0.593 & 0.669 & -0.109 \\ 10 & -0.514 & -0.563 & -0.304 & -0.739 & -0.364 & 0.073 & 0.291 \\ 11 & -0.378 & 0.155 & 0.654 & -0.128 & -0.705 & -0.585 & 0.064 \\ 12 & 0.406 & 0.363 & 0.284 & 0.490 & -0.060 & -0.252 & -0.098 \\ 13 & 0.327 & 0.235 & 0.178 & 0.309 & 0.178 & -0.024 & -0.111 \\ 14 & 0.439 & -0.243 & -0.219 & 0.009 & 0.471 & 0.339 & -0.1110 \\ 15 & 0.497 & -0.147 & -0.119 & 0.090 & 0.384 & 0.217 & -0.113 \\ 16 & 0.689 & -0.039 & -0.048 & 0.251 & 0.351 & 0.143 & -0.130 \\ 17 & 0.748 & 0.089 & 0.123 & 0.421 & 0.179 & -0.028 & -0.107 \\ 18 & -0.180 & -0.401 & -0.426 & -0.297 & 0.678 & 0.684 & -0.138 \\ 19 & 0.022 & -0.281 & -0.330 & -0.246 & 0.407 & 0.417 & -0.077 \\ 20 & -0.277 & -0.669 & -0.689 & -0.526 & 0.675 & 0.886 & -0.078 \\ 21 & -0.231 & -0.626 & -0.726 & -0.451 & 0.833 & 0.969 & -0.111\end{array}$


TABLE III

ELEMENTAL CORRELATION COEFFICIENTS FOR OPAQUE MINERAL FRACTION OF RIVER, BEACH, AND SHELF SANDS IN OREGON AND NORTHERN CALIFORNIA, 40.5-46.5 DEGREES LATITUDE (Continued)

$\begin{array}{cccccccc} & 8 & 9 & 10 & 11 & 12 & 13 & 14 \\ 1 & -0.438 & -0.376 & -0.514 & -0.378 & 0.406 & 0.327 & 0.439 \\ 2 & 0.119 & -0.502 & -0.563 & 0.155 & 0.363 & 0.235 & -0.243 \\ 3 & 0.654 & -0.335 & -0.304 & 0.654 & 0.284 & 0.178 & -0.219 \\ 4 & -0.140 & -0.443 & -0.739 & -0.128 & 0.490 & 0.309 & 0.009 \\ 5 & -0.618 & 0.593 & -0.364 & -0.705 & -0.060 & 0.178 & 0.471 \\ .6 & -0.513 & 0.669 & 0.073 & -0.585 & -0.252 & -0.024 & 0.339 \\ 7 & 0.036 & -0.109 & 0.291 & -0.064 & -0.098 & .0 .111 & -0.110 \\ 8 & 1.000 & -0.096 & 0.200 & 0.965 & -0.051 & -0.100 & -0.469 \\ 9 & -0.096 & 1.000 & -0.019 & -0.206 & -0.111 & 0.207 & 0.284 \\ 10 & 0.200 & -0.019 & 1.000 & 0.254 & -0.402 & -0.385 & -0.261 \\ 11 & 0.965 & -0.206 & 0.254 & 1.000 & -0.044 & -0.133 & -0.477 \\ 12 & -0.051 & -0.111 & -0.402 & -0.044 & 1.000 & 0.650 & 0.215 \\ 13 & -0.100 & 0.207 & -0.385 & -0.133 & 0.650 & 1.000 & 0.311 \\ 14 & -0.469 & 0.284 & -0.261 & -0.477 & 0.215 & 0.311 & 1.000 \\ 15 . & -0.399 & 0.181 & -0.276 & -0.411 & 0.289 & 0.428 & 0.951 \\ 16 & -0.470 & 0.126 & -0.425 & -0.457 & 0.378 & 0.446 & 0.909 \\ 17 & -0.333 & -0.007 & -0.480 & -0.297 & 0.481 & 0.489 & 0.715 \\ 18 & -0.353 & 0.861 & -0.170 & -0.441 & -0.040 & 0.161 & 0.427 \\ 19 & -0.312 & 0.469 & -0.053 & -0.329 & -0.127 & -0.012 & 0.354 \\ 20 & -0.385 & 0.602 & 0.105 & -0.458 & -0.206 & .0 .070 & 0.375 \\ 21 & -0.504 & 0.695 & -0.028 & -0.589 & -0.199 & 0.022 & 0.408\end{array}$


TABLE III

ELEMENTAL CORRELATION COEFFICIENTS FOR OPAQUE MINERAL FRACTION OF RIVER, BEACH, AND SHELF SANDS IN OREGON AND NORTHERN CALIFORNIA, 40.5-46.5 DEGREES LATITUDE (Continued)

$\begin{array}{rccccccc} & 15 & 16 & 17 & 18 & 19 & 20 & 21 \\ 1 & 0.497 & 0.689 & 0.748 & -0.180 & 0.022 & -0.277 & -0.231 \\ 2 & -0.147 & -0.039 & 0.089 & -0.401 & -0.281 & -0.669 & -0.626 \\ 3 & -0.119 & -0.048 & 0.123 & -0.426 & -0.330 & -0.689 & -0.726 \\ 4 & 0.090 & 0.251 & 0.421 & -0.297 & -0.246 & .0 .526 & -0.451 \\ 5 & 0.384 & 0.351 & 0.179 & 0.678 & 0.407 & 0.675 & 0.833 \\ 6 & 0.217 & 0.143 & -0.028 & 0.684 & 0.417 & 0.886 & 0.969 \\ 7 & -0.113 & -0.130 & -0.107 & -0.138 & -0.077 & -0.078 & -0.111 \\ 8 & -0.399 & -0.470 & -0.333 & -0.353 & -0.312 & -0.385 & -0.504 \\ 9 & 0.181 & 0.126 & -0.007 & 0.861 & 0.469 & 0.602 & 0.695 \\ 10 & -0.276 & -0.425 & -0.480 & -0.170 & -0.053 & 0.105 & -0.028 \\ 11 & -0.411 & -0.457 & -0.297 & -0.441 & -0.329 & -0.458 & -0.589 \\ 12 & 0.289 & 0.378 & 0.481 & -0.040 & -0.127 & -0.206 & -0.199 \\ 13 & 0.428 & 0.446 & 0.489 & 0.161 & -0.012 & -0.070 & 0.022 \\ 14 & 0.951 & 0.909 & 0.715 & 0.427 & 0.354 & 0.375 & 0.408 \\ 15 & 1.000 & 0.906 & 0.738 & 0.308 & 0.221 & 0.260 & 0.288 \\ 16 & 0.906 & 1.000 & 0.888 & 0.282 & 0.263 & 0.143 & 0.220 \\ 17 & 0.738 & 0.888 & 1.000 & 0.101 & 0.076 & -0.031 & 0.030 \\ 18 & 0.308 & 0.282 & 0.101 & 1.000 & 0.536 & 0.659 & 0.738 \\ .19 & 0.221 & 0.263 & 0.076 & 0.536 & 1.000 & 0.387 & 0.428 \\ 20 & 0.260 & 0.143 & -0.031 & 0.659 & 0.387 & 1.000 & 0.863 \\ 21 & 0.288 & 0.220 & 0.030 & 0.738 & 0.428 & 0.863 & 1.000\end{array}$




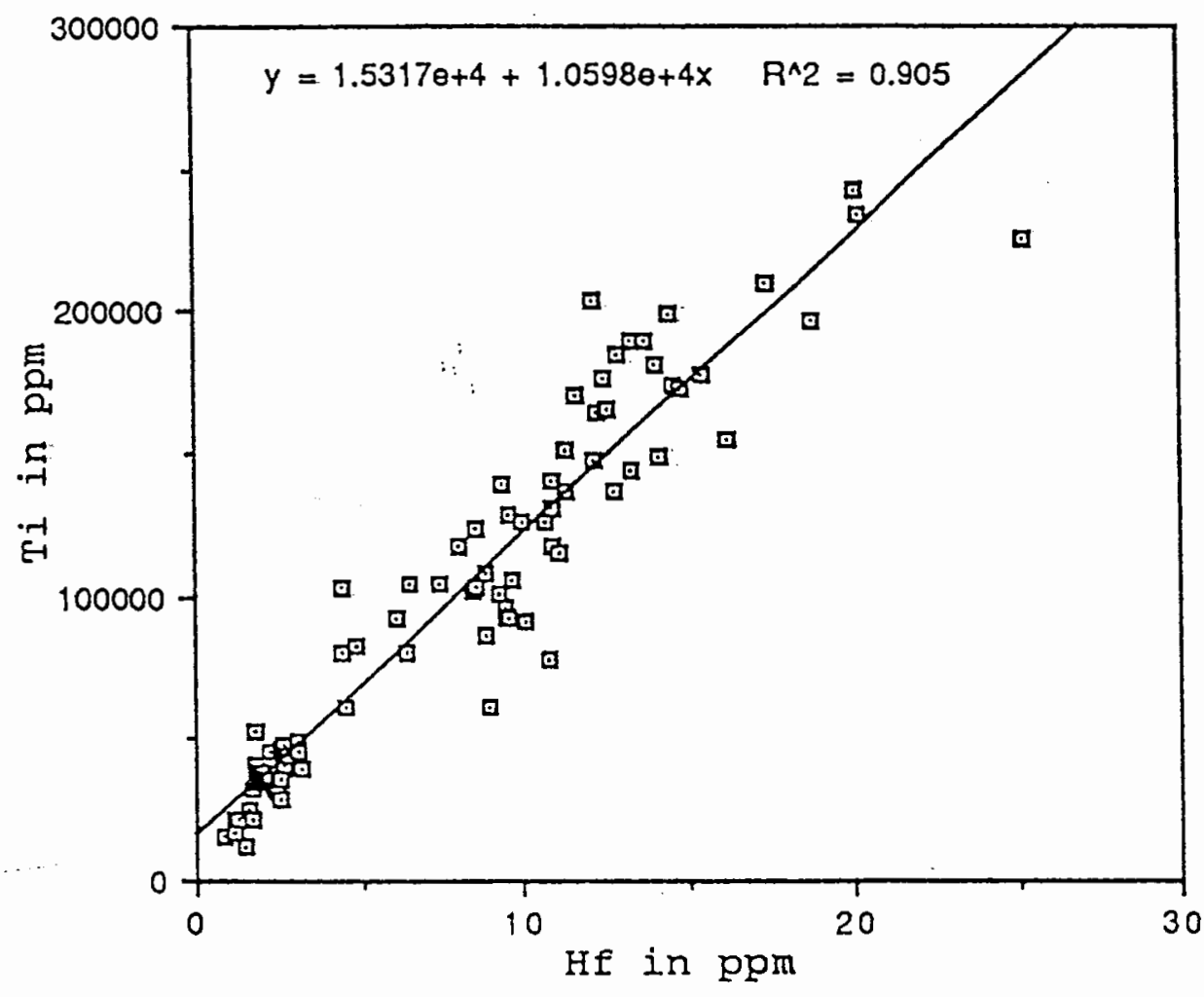

a Ti

Figure 17. Plots of Titanium and Hafnium Elemental values of opaque Mineral oxides from the continental shelf. 


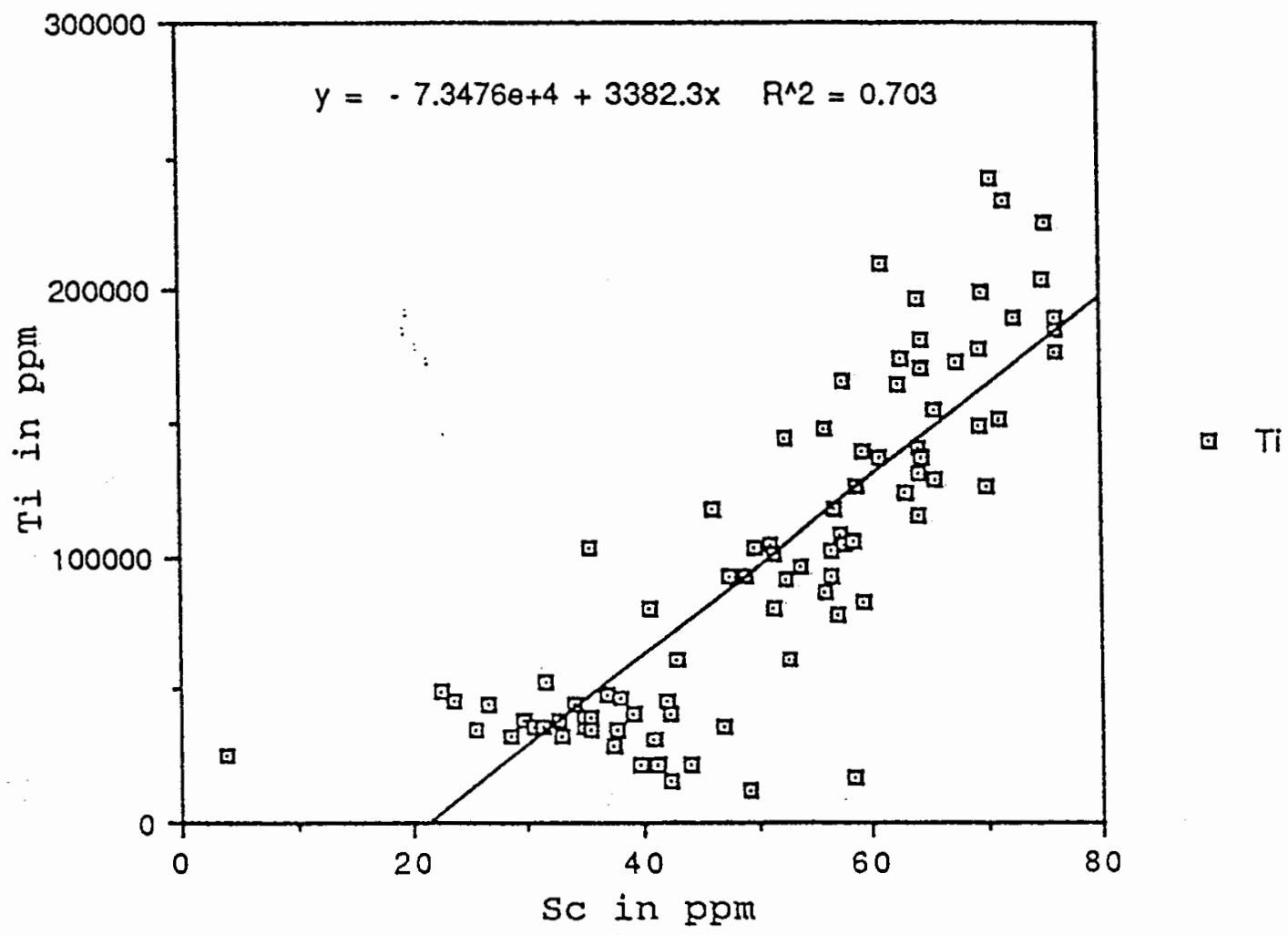

Figure 18. Plots of Titanium and Scandium Elemental Values of Opaque Mineral oxides from the continental Shelf. 


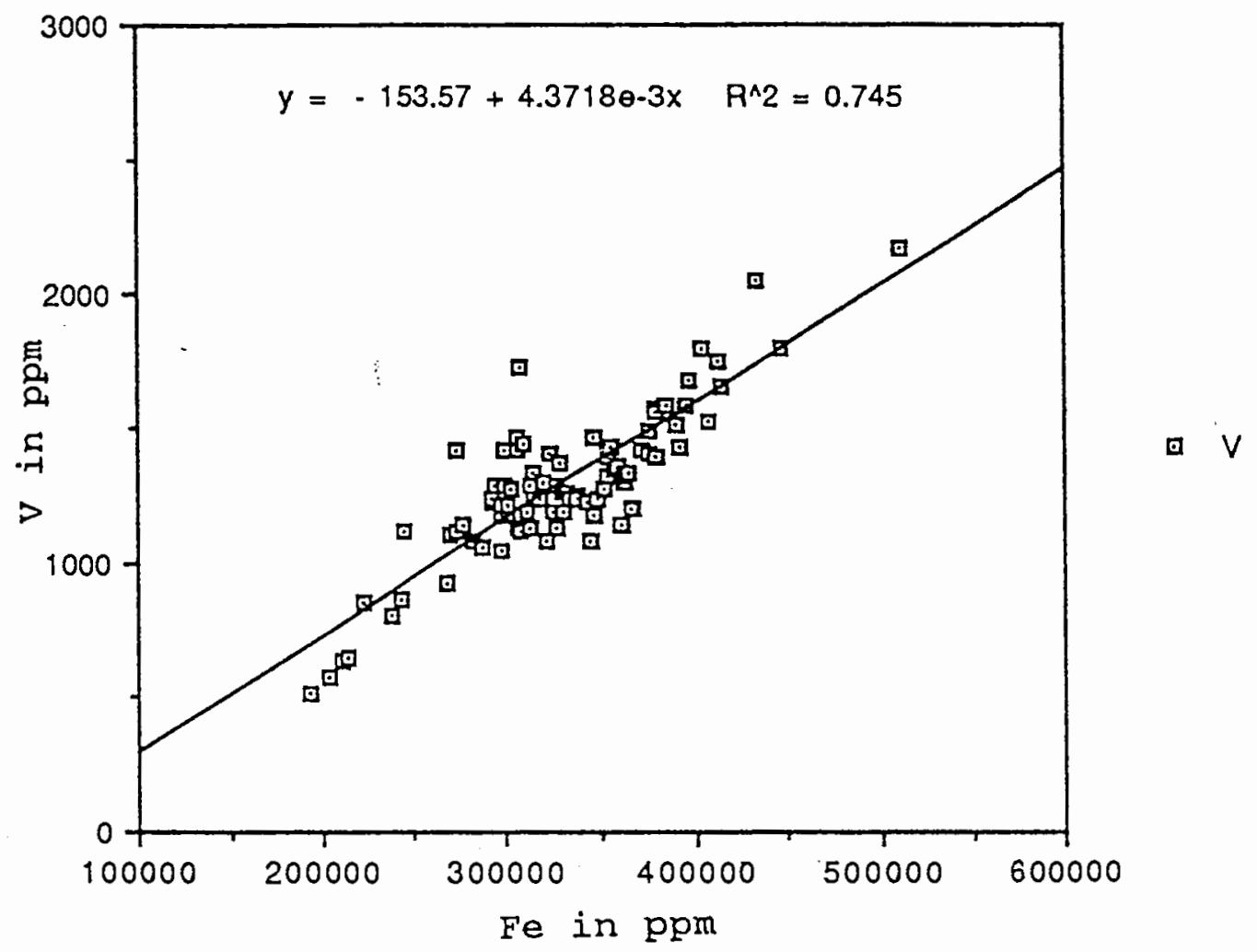

Figure 19. Plots of Iron and Vanadium Elemental Values of opaque Mineral oxides from the Continental Shelf. 
iron in the non-magnetite phases i.e., chromite and ilmenite (see Table I).

In the lanthanide group the following trace elements were detected: La (3-56 ppm), Ce (112-7 ppm), Sm (10-1 ppm), Eu $(<1.0-1.8 \mathrm{ppm})$ and $\mathrm{Lu}(<1.0-2.4 \mathrm{ppm}$; refer to Appendix A). La, $\mathrm{Hf}$, and $\mathrm{Ce}$ in the lanthanide group show similar abundance trends as a function of latitude i.e., increasing to the north (Figures 20-22). The remaining rare earth elements show only weak or no increases from south to north in the study area (refer to Figures 20-27).

The light rare earth element (LREE) abundances are generally incompatible with the oxide minerals, and their variable abundances might reflect distinct source areas. Plots of the LREE (La-Sm) abundances as a function of latitude (Figures 20, 21, and 22) can be used to discriminate distinct geochemical source terranes. Low values of $\mathrm{La}, \mathrm{Ce}$, and $\mathrm{Sm}$ generally reflect the Klamath Mountain source $\left(42-43^{\circ}\right)$, slightly higher values (La, Ce, and Sm) occur to the south around $41^{\circ}$ possibly reflecting the Eel River draining the California Coast range. Maximum values of $\mathrm{La}(56 \mathrm{ppm}), \mathrm{Ce}(112 \mathrm{ppm})$, and $\mathrm{Sm}(9 \mathrm{ppm})$ are associated with a sample collected offshore of the columbia River $\left(46^{\circ}\right)$. Figures $23-27$ show the variation of $E u$ and $Y b$, Hf, and Ta-HREE (heavy rare earth element) respectively as a function of latitude. The high values of $\mathrm{Eu}$ (1.4-1.8 ppm, Figure 23) clearly define the opaque oxides derived from the 


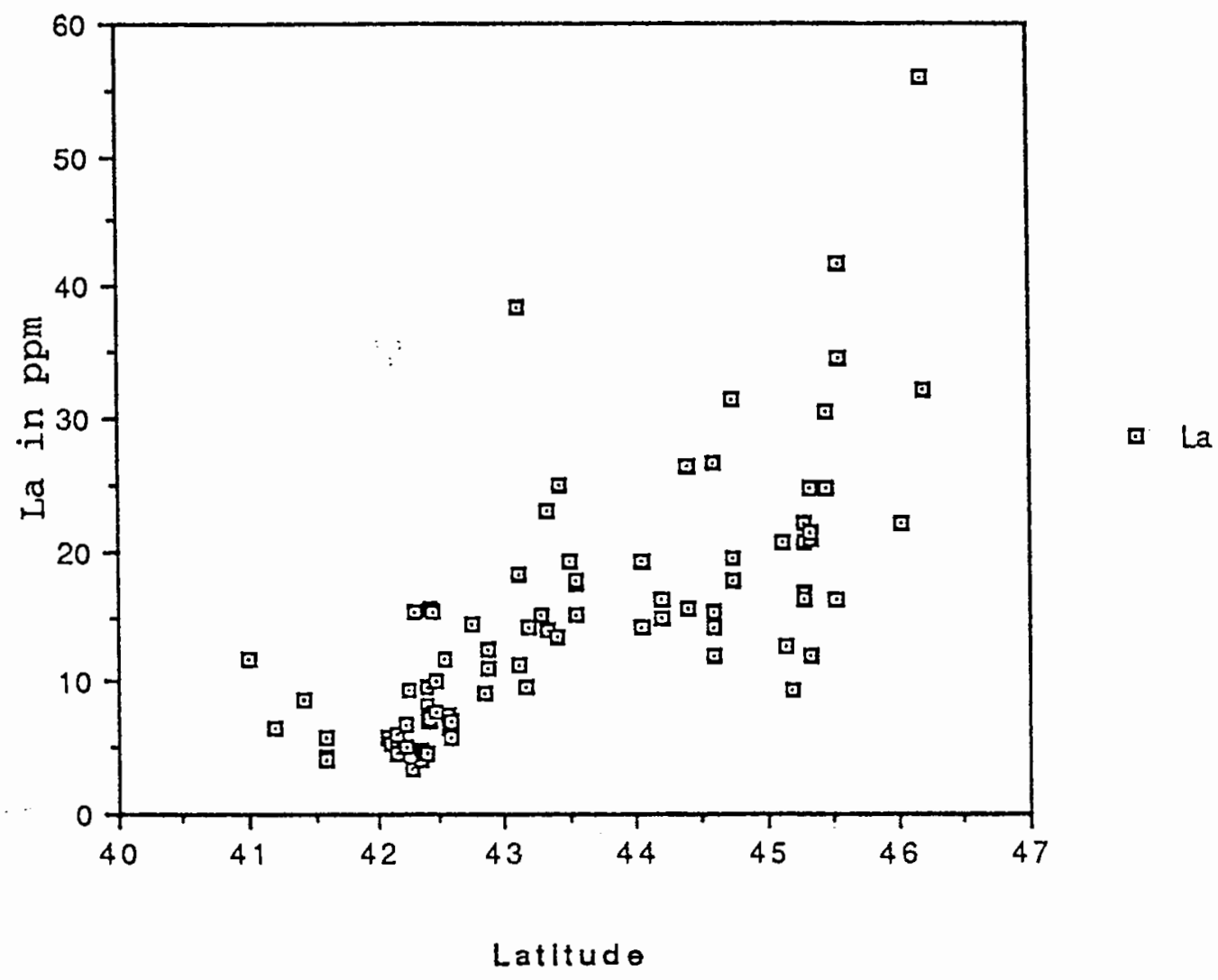

Figure 20. Plot of Lanthanum Elemental Abundance as a Function of Degrees Latitude. 


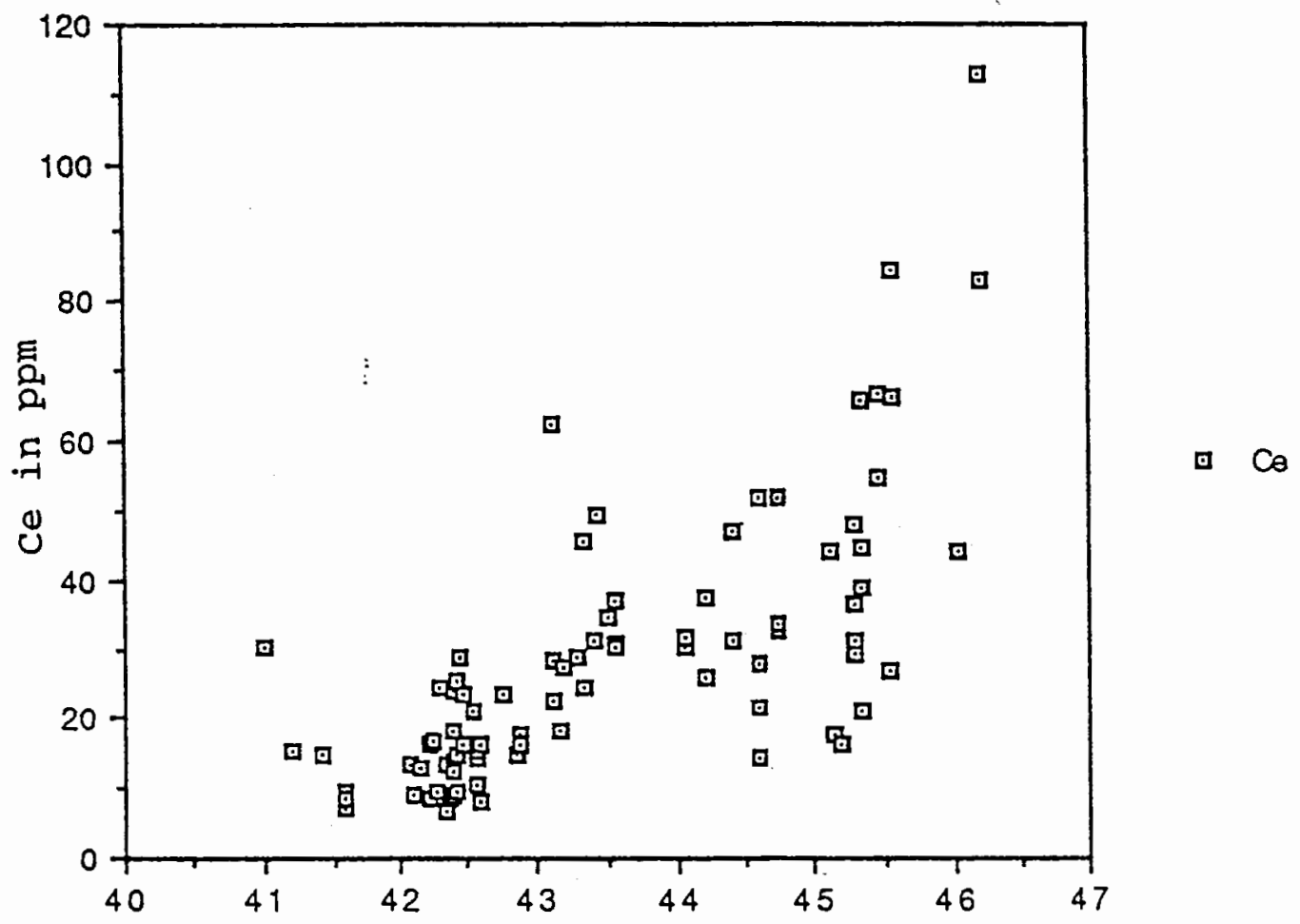

Latlitude

Figure 21. Plot of Cerium Elemental Abundance as a Function of Degrees Latitude. 


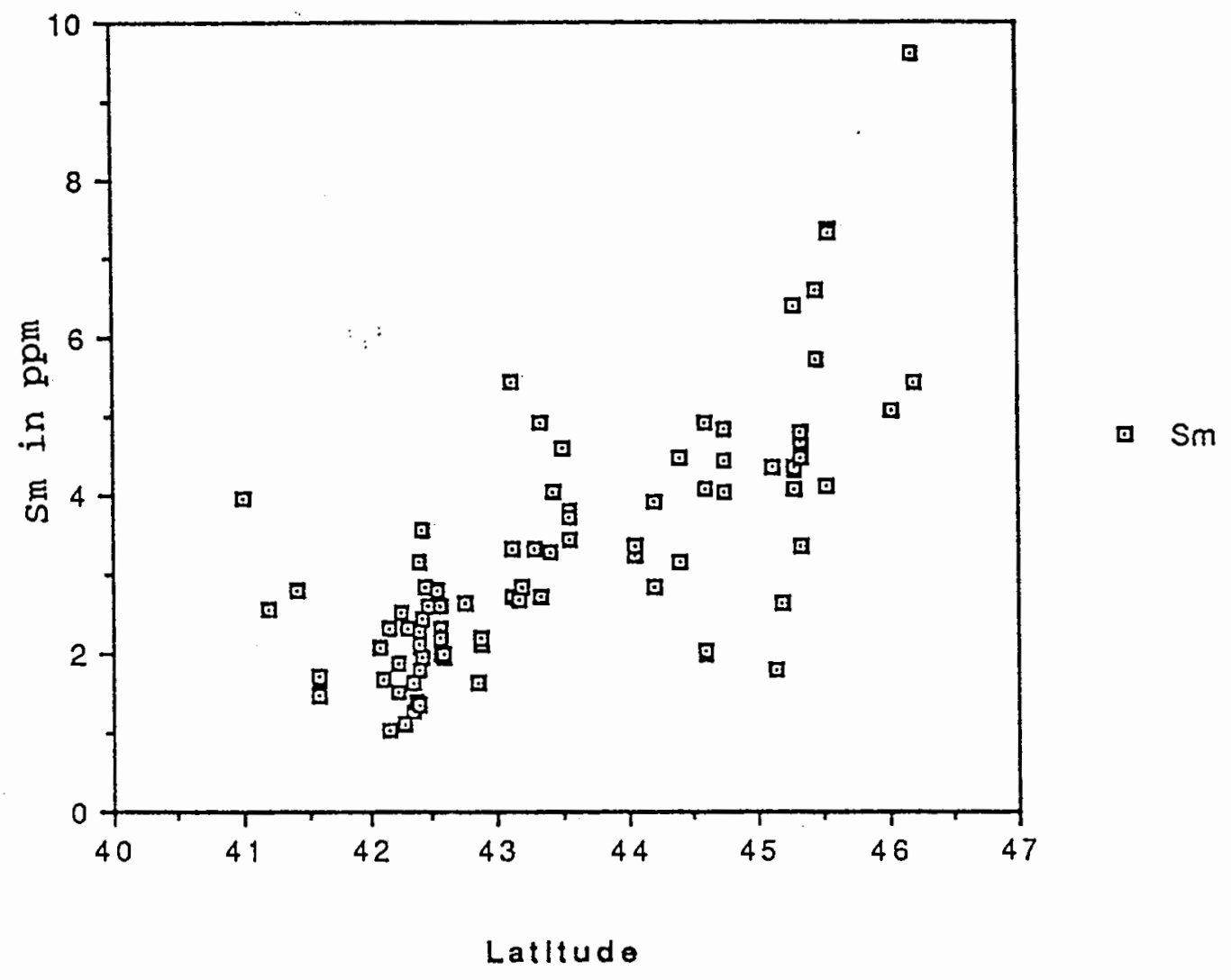

Figure 22. Plot of Samarium Elemental Abundance as a Function of Degrees Latitude. 


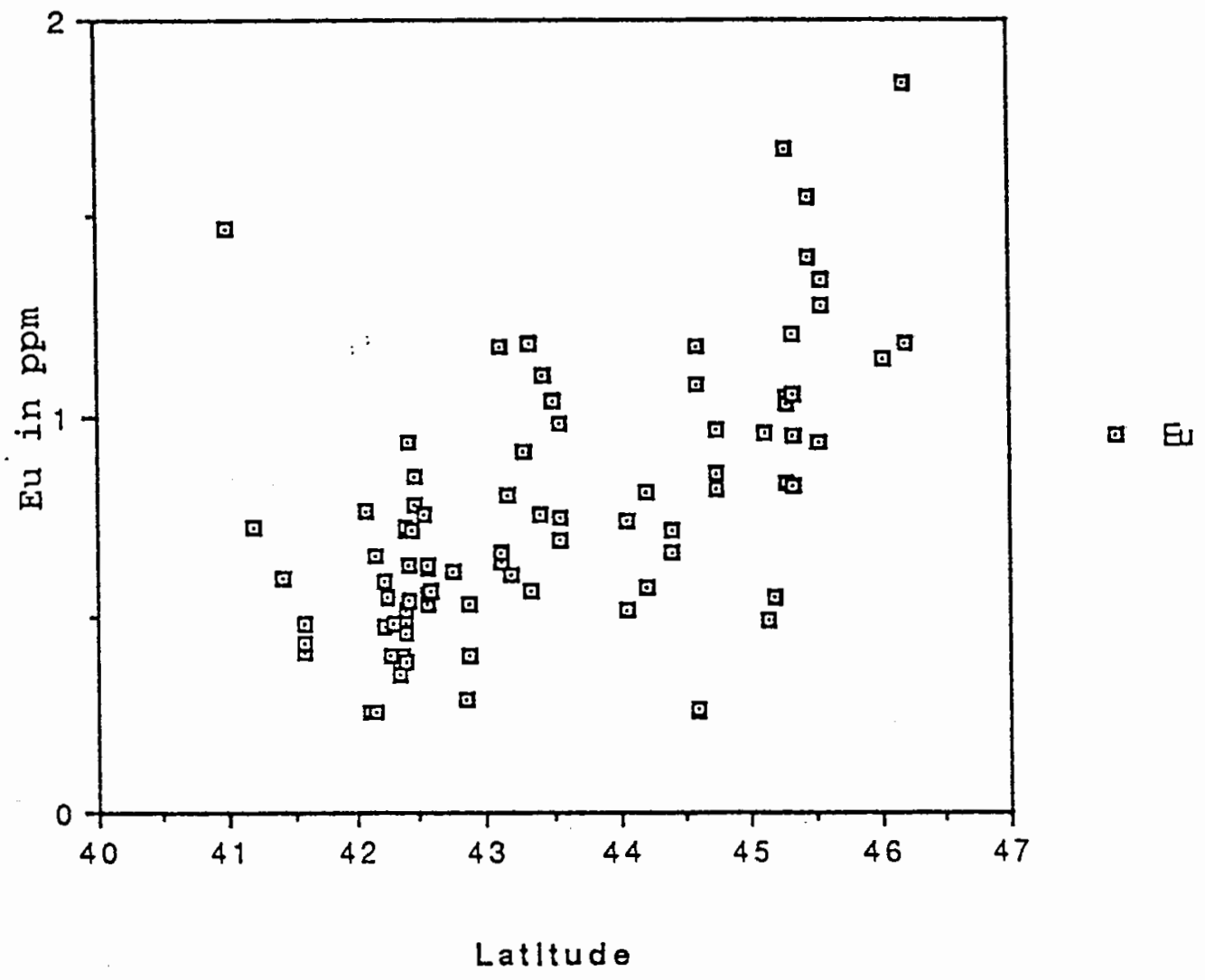

Figure 23. Plot of Europium Elemental

Abundance as a Function of Degrees Latitude. 


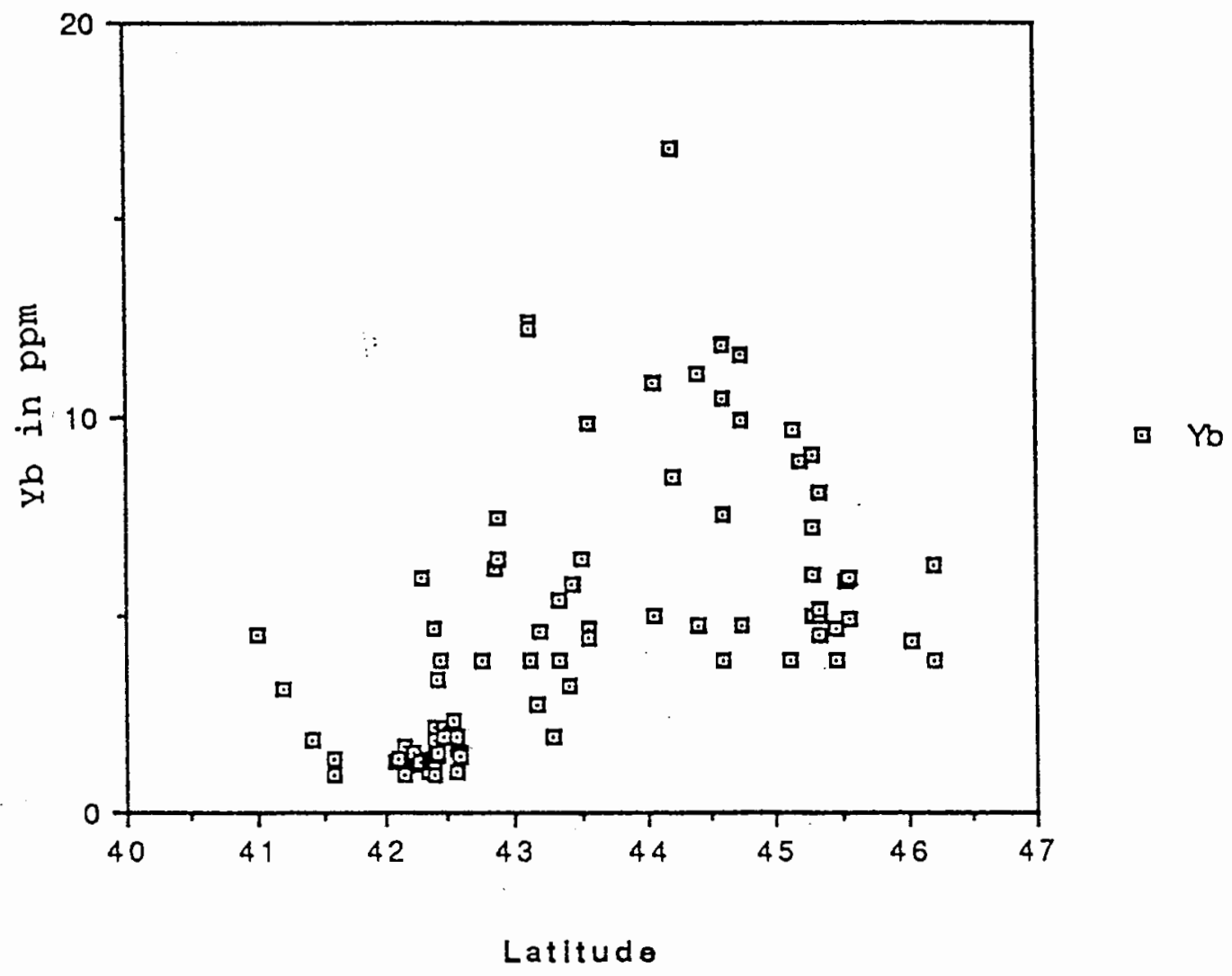

Figure 24. Plot of Ytterbium Elemental Abundance as a Function of Degrees Latitude. 


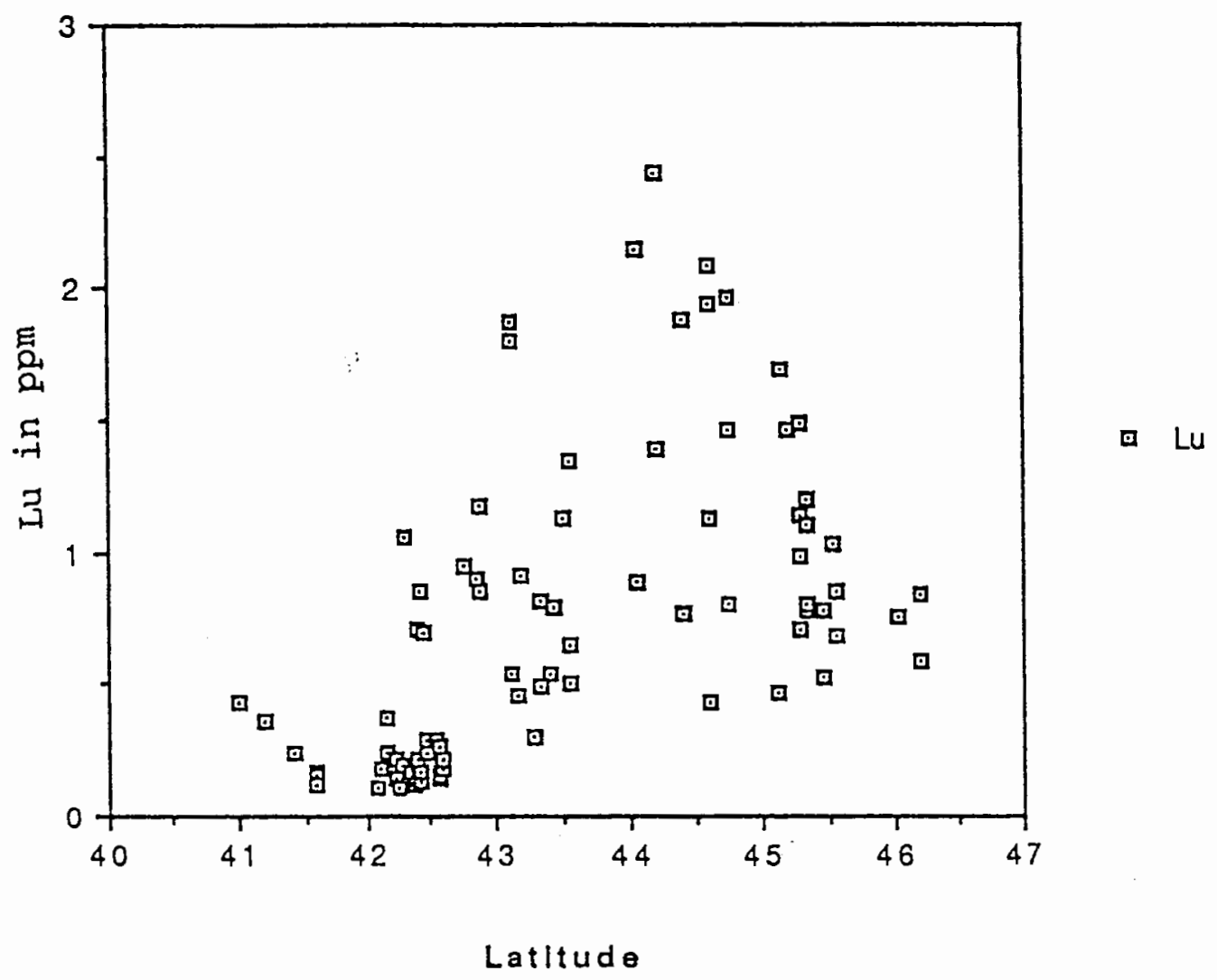

Figure 25. Plot of Lutecium Elemental

Abundance as a Function of Degrees Latitude. 


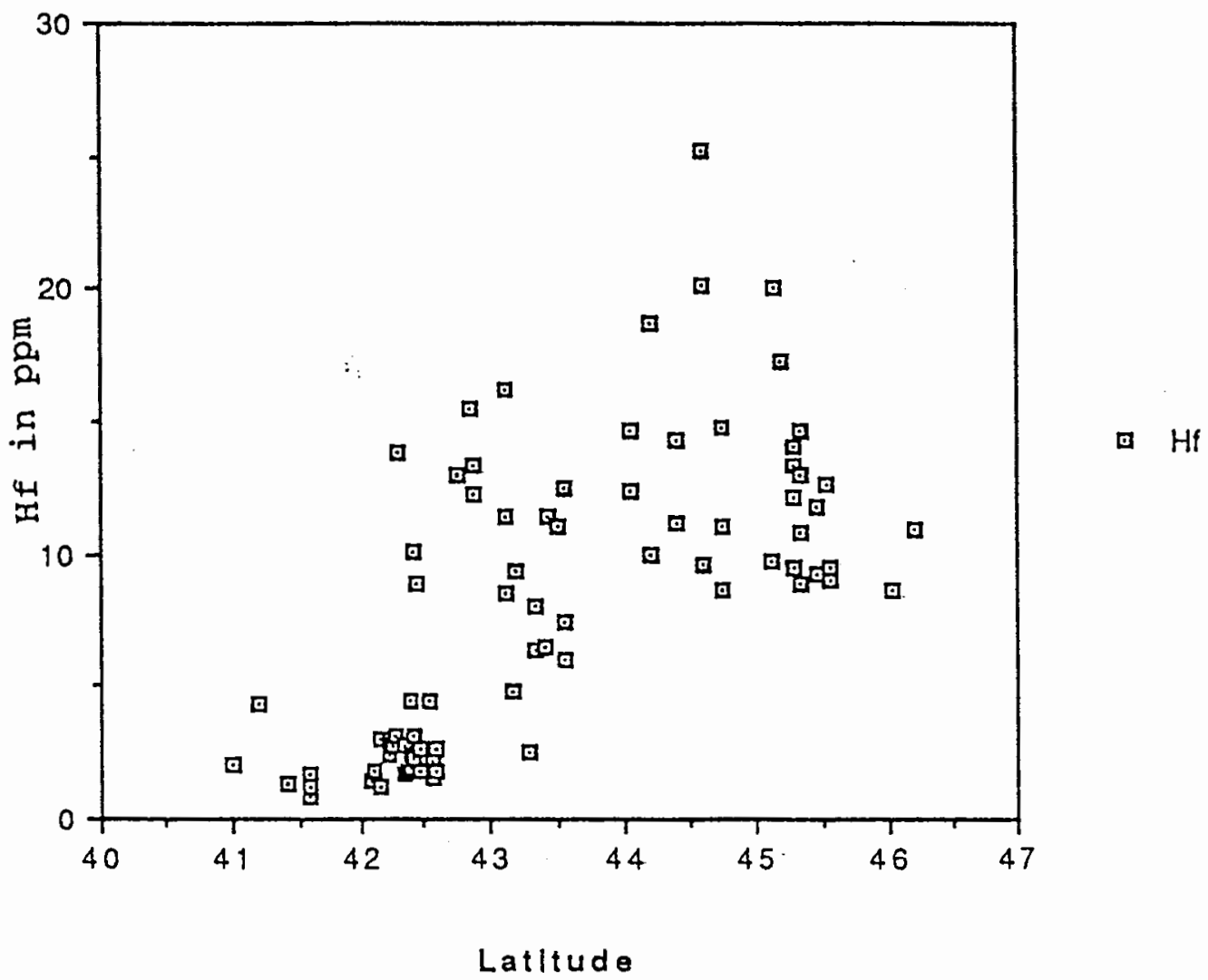

Figure 26. Plot of Hafnium Elemental

Abundance as a Function of Degrees Latitude. 


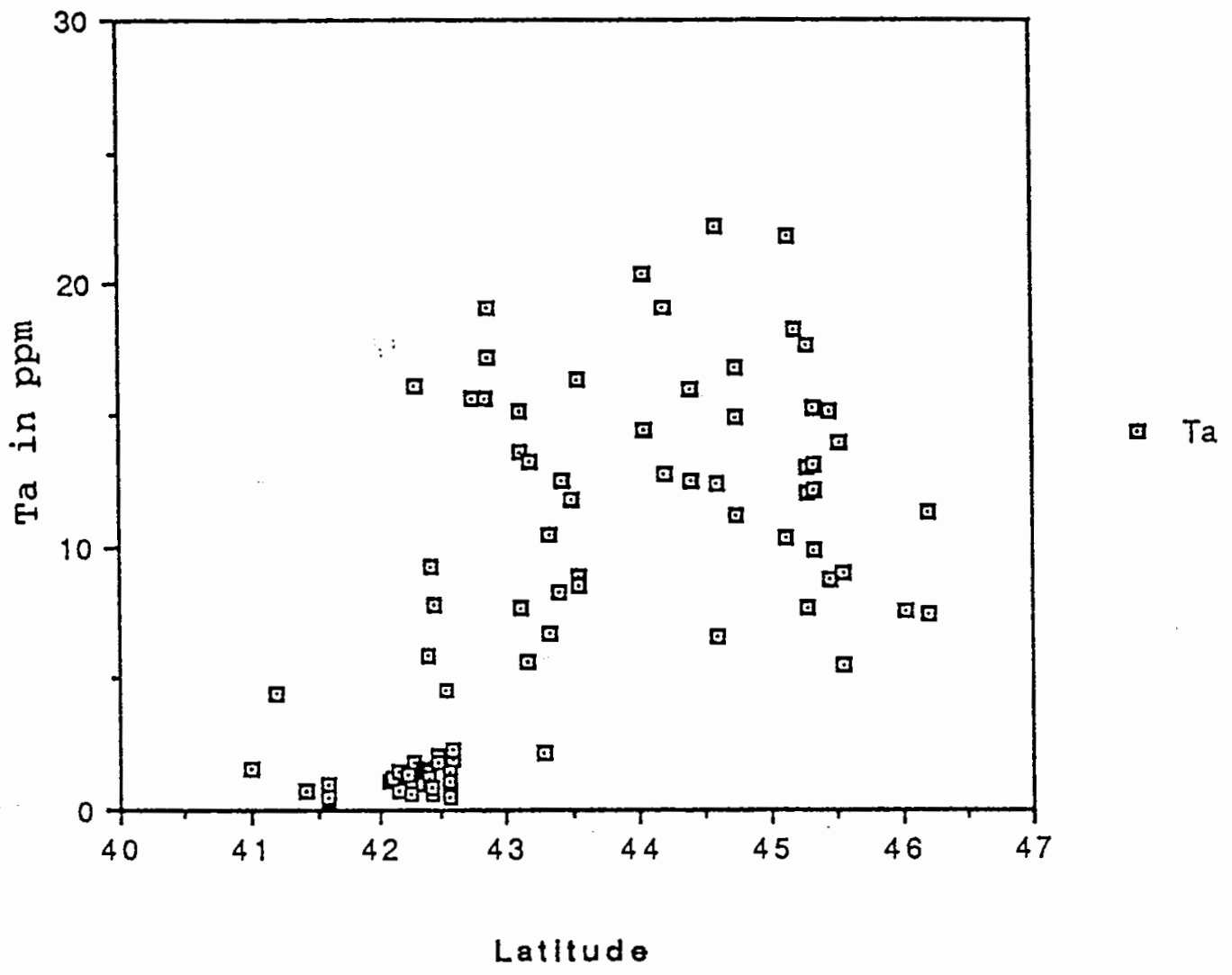

Figure 27. Plot of Tantalum Elemental

Abundance as a Function of Degrees Latitude. 
most southern drainage (south of $41^{\circ}$ ) and from the columbiaRiver source north of $46^{\circ}$. In contrast, maximum values of $\mathrm{Yb}, \mathrm{Lu}$, and Hf-HREE (Figures 24-27) reflect the northern Coast Range basalts, and not the Columbia River source. The Ta-HFSE (high field strength element) follows the high ilmenite abundance from the oregon coast range as noted previously.

The chondrite-normalized REE distribution patterns for shelf opaque oxides are shown in Figures 28-30. The chondritic values used are those determined by Taylor and Mclennan, 1985. The chondrite-normalized REE distribution patterns for shelf opaque oxide minerals derived from discrete source provinces i.e., Klamath Mountain, Coast Range and Columbia River respectively, demonstrate (Figures 28-30) generally similar fractional crystallization and differentiation processes. Although, the LREE distributions. are very slightly enriched for coast Range and columbia River provinces relative to the Klamath provenance. Since, the REE's have not fractionated relative to each other, REE ratios ( $\mathrm{La} / \mathrm{Sm}, \mathrm{La} / \mathrm{Yb}$ and $\mathrm{Ce} / \mathrm{Yb}$ ) are used to trace the source of opaque oxides. High values of $(>7.0)$ of La/Sm ratio (Figure 31) indicate the greatest degree of LREE enrichment. High values of $\mathrm{La} / \mathrm{Yb}$ and $\mathrm{Ce} / \mathrm{Yb}$ ratios (Figures 32-33) for bulk opaque oxides reflect the accreted source terrains associated with Klamath and coast Range basalts. 


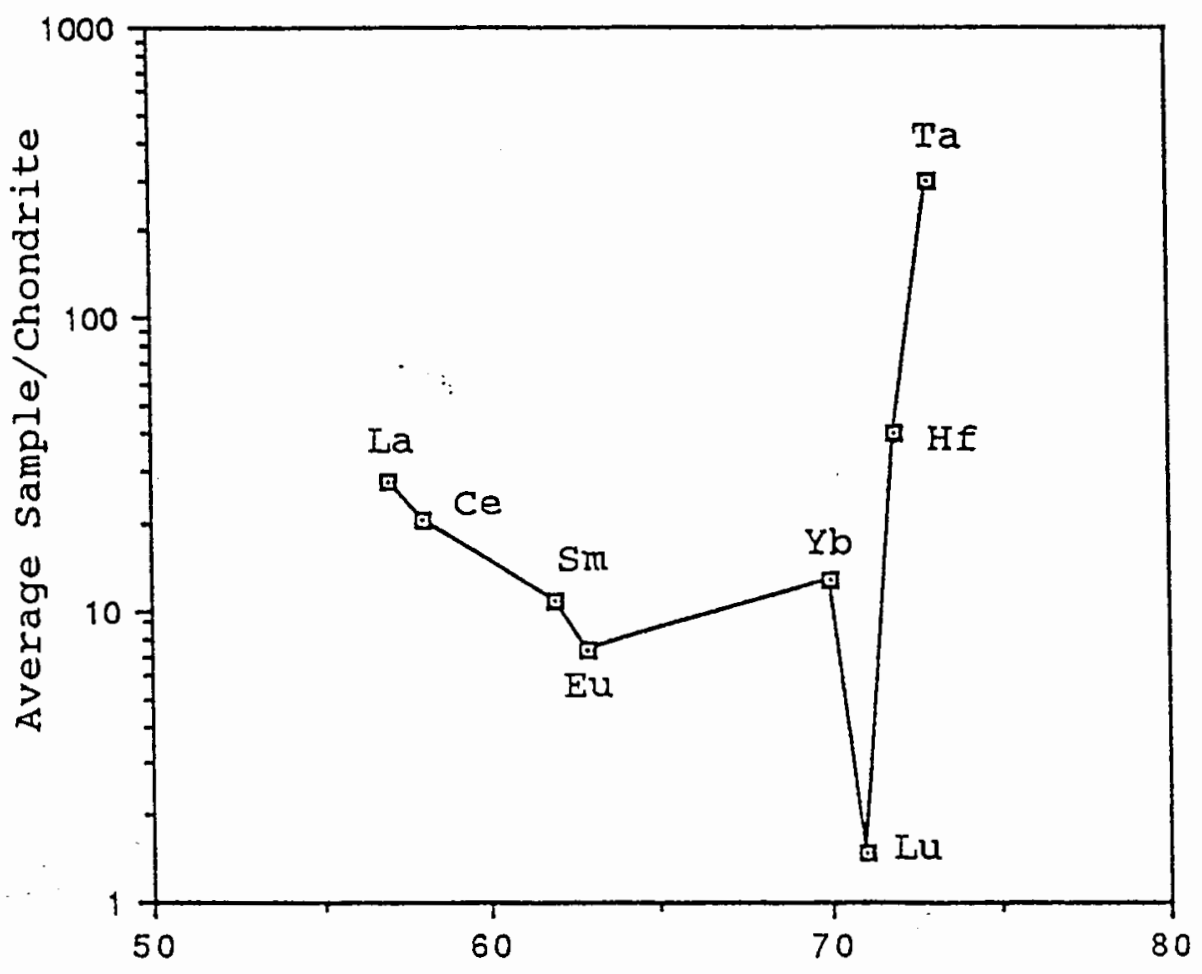

Atomic Number

Figure 28. Chondrite-Normalized REE Distributions in Shelf opaque oxide Minerals Derived from Klamath Mountain Provenance (north of 41-42 degrees latitude). 


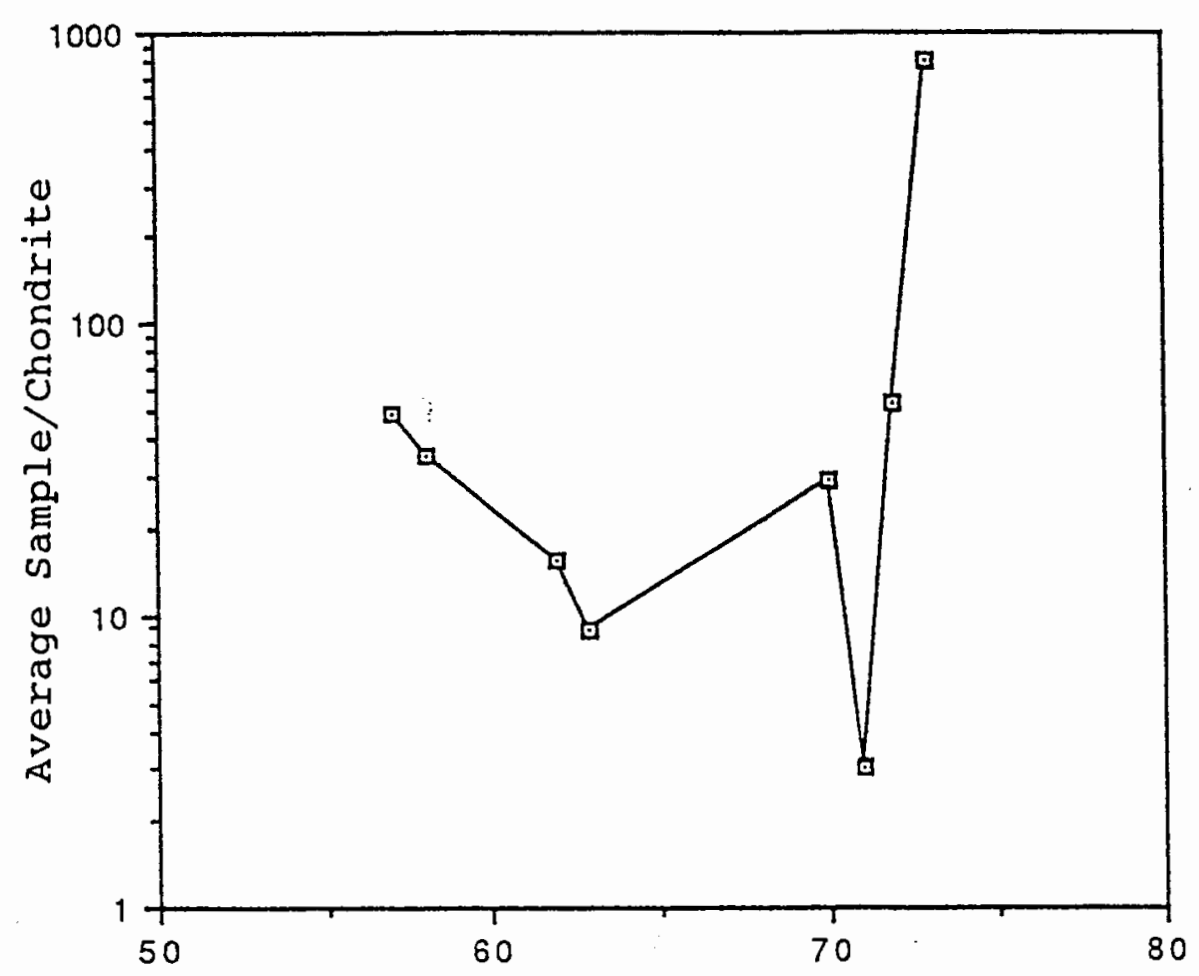

Atomic Number

Figure 29. Chondrite-Normalized REE Distributions in Shelf opaque Oxide Minerals Derived from coast Range provenance (north of 43-44 degrees latitude). 


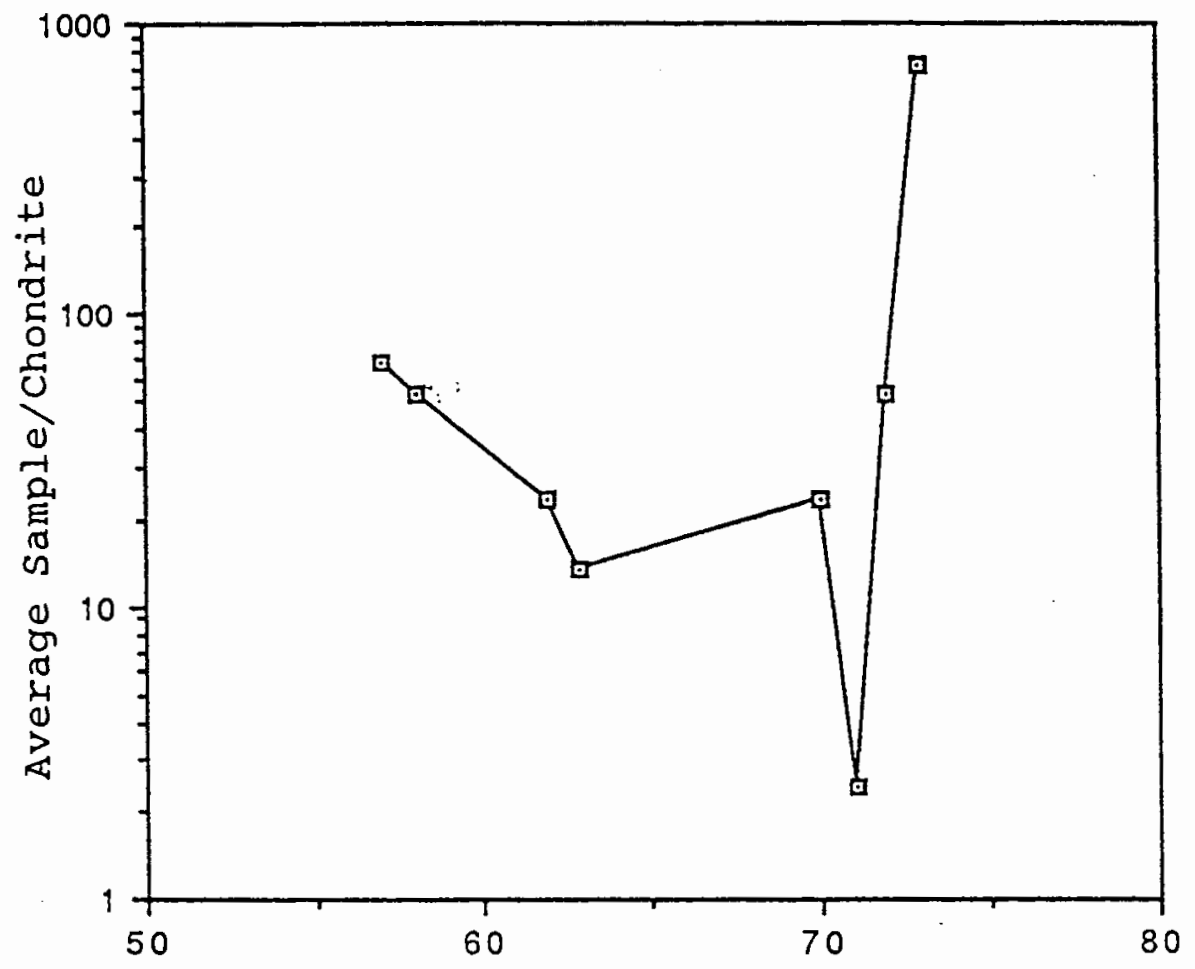

Atamic Number

Figure 30. Chondrite-Normalized REE Distributions in Shelf opaque oxide Minerals Derived from Columbia River Provenance (north of 45-46 latitude). 


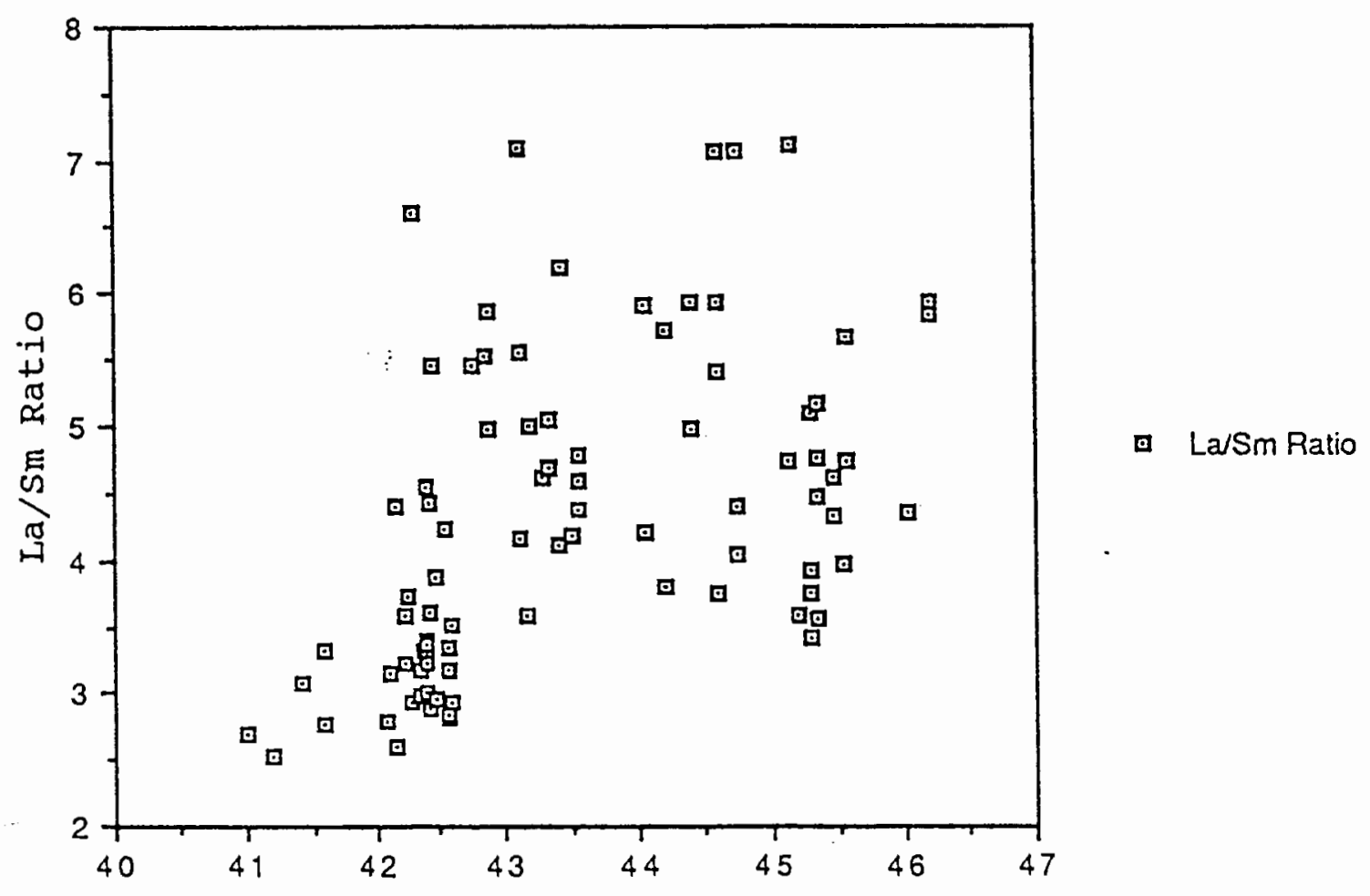

Latitude

Figure 31. Distributions of Shelf Opaque Oxide Minerals on a La/Sm Ratio vs Latitude Diagram. 


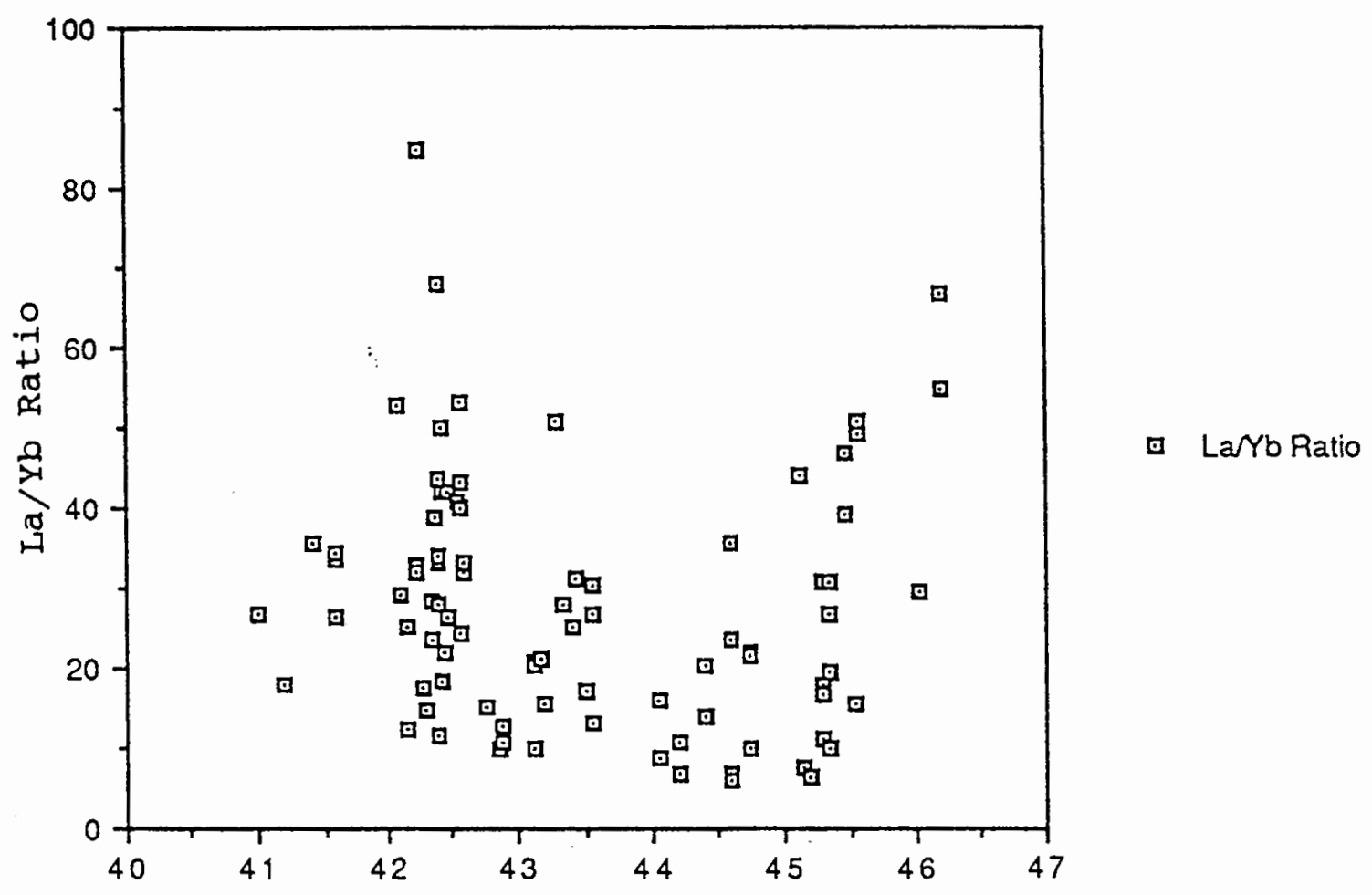

Latlitude

Figure 32. Distributions of Shelf Opaque Oxide Minerals on a La/Yb Ratio vs Latitude Diagram. 


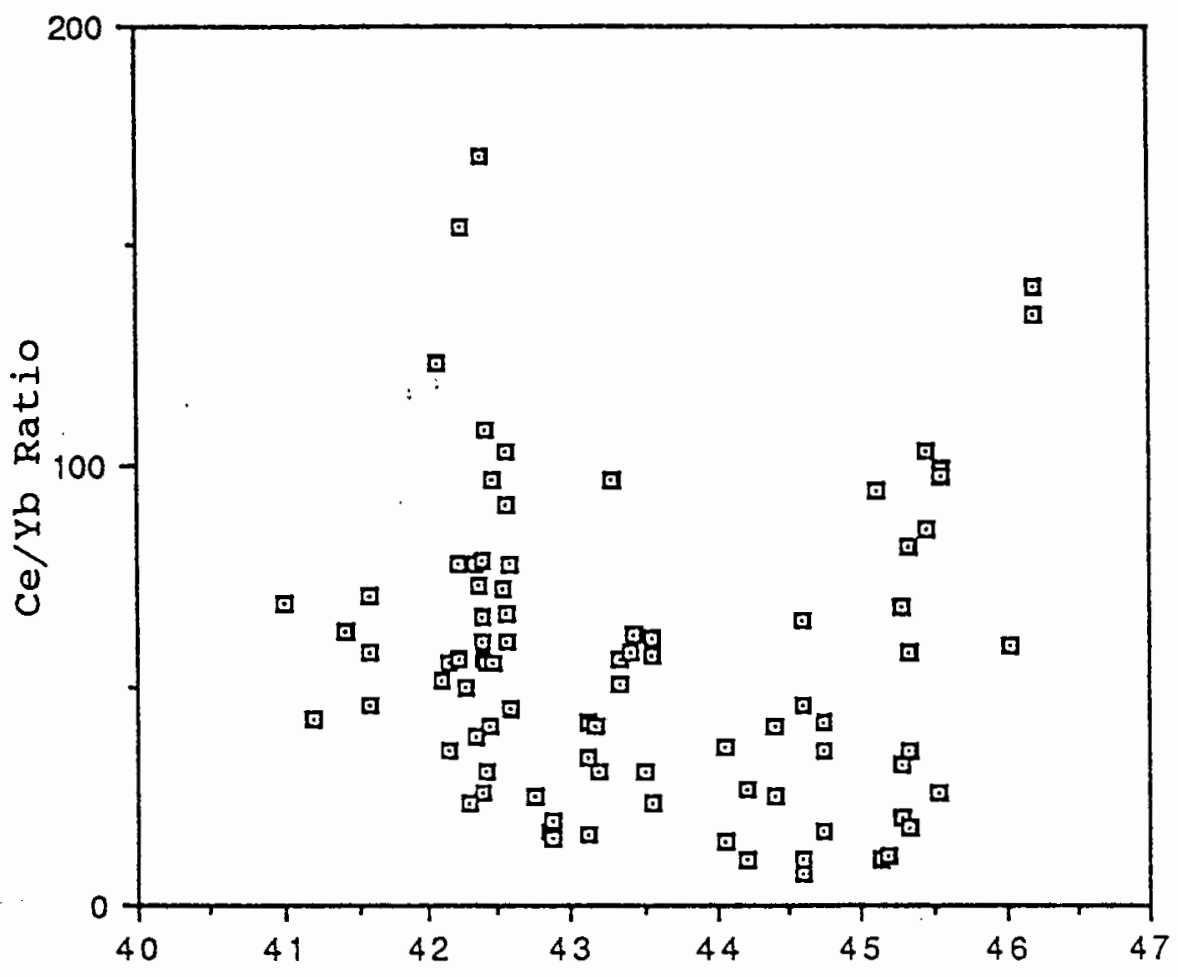

- Ceryo Ratio

\section{Latitude}

Figure 33. Distributions of Shelf opaque Oxide Minerals on a Ce/Yb Ratio vs Latitude Diagram. 


\section{MINERAL-GRAIN HYDRODYNAMIC RELATIONS}

An understanding of the relative abundances of opaque minerals in different grain size distributions is needed to evaluate potential mineral sorting mechanisms across the river-beach-shelf environments of the continental margin.

One river (sixes) of the south-central oregon coast was sampled for detailed analysis of mineral-grain size relations. Composite samples include fine to coarse sediments from channel axis, point bar and flood over-bank deposits. The composite river sample $(1 \mathrm{~kg})$ was sieved for three representative grain size ranges, 300-250 microns, 175-125 microns and less than 75 microns. The sample splits were processed for opaque mineral splits in Sodium Polytungstate solution (refer to Sample Preparation) and were mounted and polished for mineral-size analysis by $\mathrm{SEM} / \mathrm{microprobe} \mathrm{EDX}$. Initial results from the sixes River are shown in Table IV. Chromite rather than ilmenite seems to be preferentially concentrated in the finer grain size fractions for this river. The hypothesis that coarse grained chromite from coarse grained source rocks would be selectively deposited in beach deposits at the expense of fine grained ilmenite (Peterson and Binney, 1988) is not supported by these results. Relatively high ilmenite values in shelf sediments must reflect shelf dispersal patterns 
TABLE IV

PRELIMINARY GRAIN SIZE FREQUENCIES OF OPAQUE MINERAL DISTRIBUTIONS IN THE SIXES RIVER, OREGON

Grain Size (microns) Magnetite Ilmenite Chromite

\begin{tabular}{lccc}
\hline $300-250$ & $45 \%$ & $45 \%$ & $10 \%$ \\
$175-125$ & $19 \%$ & $31 \%$ & $50 \%$ \\
$<75$ & $33 \%$ & - & $66 \%$
\end{tabular}


patterns that differ from those of modern beach deposits.

High concentrations of heavy minerals occur as

isolated placer deposits on modern beaches and in

Pleistocene beach terraces of the Pacific Northwest (PNW) .

The top, bottom and middle of six box cores (maximum

penetration of $40 \mathrm{~cm}$; Figure 34) showing increasing heavy

mineral content with depth are chosen to calculate grain

size statistics of quartz and magnetite grains. These

results are used to evaluate settling velocity equivalence

and critical shear stress values of the light and heavy

minerals. The results from this analysis should help to

test the onshore versus offshore origins of the shelf

placers.

The modified Gibb's equation (Komar, 1981) for the grain settling velocities was used to calculate hydrodynamic settling velocities for quartz and magnetite respectively. The analysis of the quartz-density grains have yielded an average $R_{\phi}=1.0269$. Average $R_{\phi}$ values for a range of grain densities provided by Komar (1981), were used in equation (1) to reduce systematic errors in the evaluation of grain settling rates in water,

$$
W_{g}=\frac{-3 \mu+\sqrt{9 \mu^{2}+g I^{2} \rho\left(\rho_{s}-\rho\right)(0.015476+0.19841 r)}}{\rho(0.011607+0.14881 r)}
$$


where $W_{\eta}(\mathrm{cm} / \mathrm{sec})$ is the settling velocity, $r(\mathrm{~cm})$ is the sphere radius, $u$ (poise) is the water dynamic viscosity, $g$ $\left(\mathrm{cm} / \mathrm{sec}^{2}\right)$ is the accelaration of gravity, and ps and $p$ $\left(\mathrm{g} / \mathrm{cm}^{3}\right)$ are the grain and water densities respectively. Entrainment Shear stress of measured quartz and magnetite mineral grains (Komar and Wang, 1984) is used to establish potential winnowing effects from offshore currents.

$$
T_{x}-0.00515 g\left(\rho_{s}-\rho\right) D b^{0.668}\left[\tan \left(61.5(D b / k s)^{-0.3}\right)\right]
$$

where $\mathrm{Tx}$ is critical shear stress, $g$ is gravitational force, $\mathrm{Db}$ is grain intermediate diameter, $\mathrm{p}$ is fluid density, ps is grain-density, and $k s$ is bed roughness or mean size of bed particles (Komar and Wang, 1984).

Six box core samples (6708-62B, 6708-62T, 6708-67B, 6708-67T, 6708-70B, and 6708-70T) from the inner-shelf off Cape Blanco, southern Oregon (Figure 34), were selected for analysis of heavy-mineral sorting mechanisms. Each of the six samples were split for light-, heavy-, and magnetic mineral separation. Three mineral splits, including magnetite, (2) quartz, and (3) bulk, were analyzed for intermediate grain diameter $(D b)$, based on optical micrometer measurements of at least 100 grains per sample. Magnetite grains were separated by using a hand magnet. The sample grain size distributions are shown in Table $V$. 


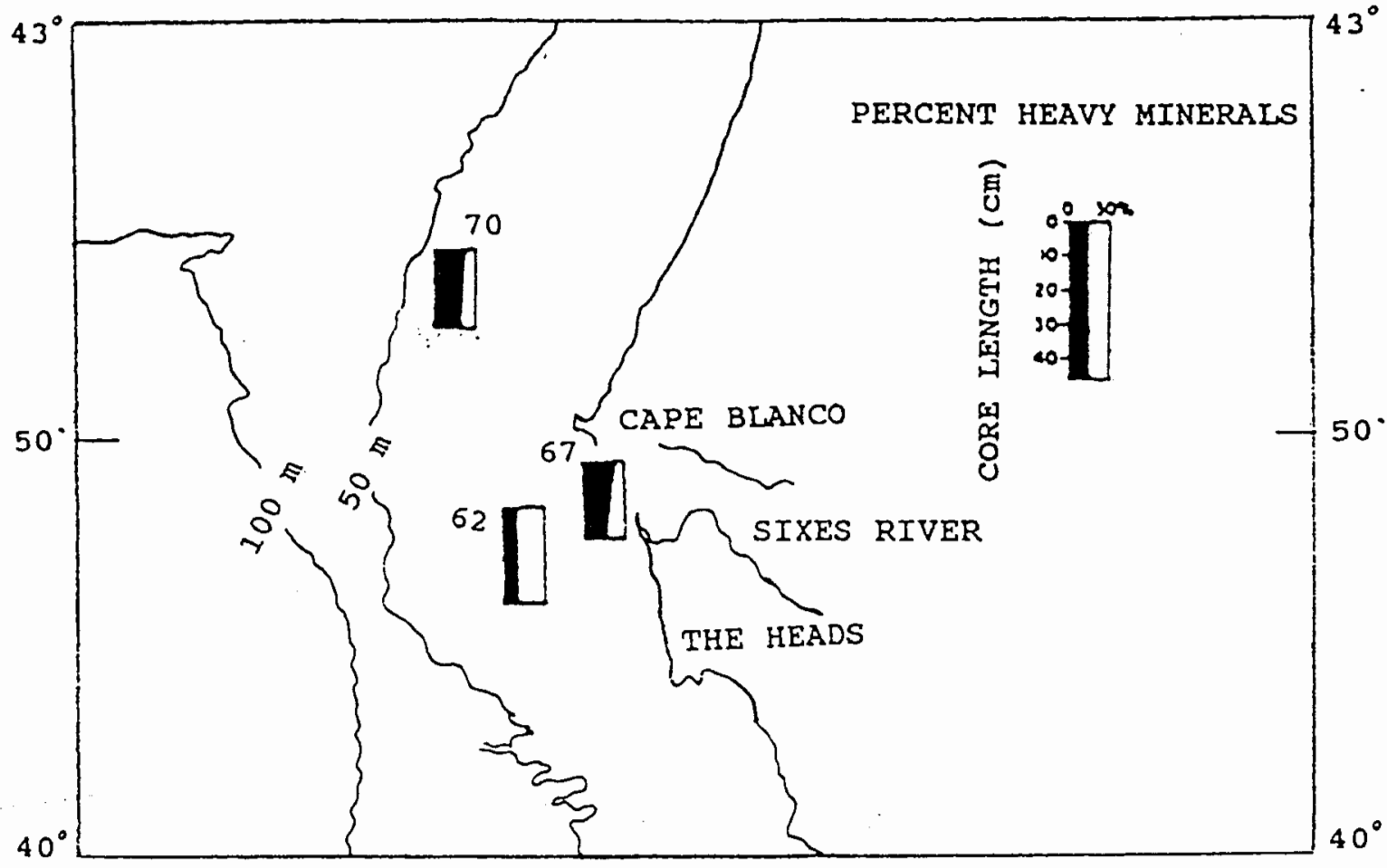

Figure 34. Location Map and Heavy Mineral Concentrations in short Box Cores used in Mineral Grain-Size Statistics (Modified from Kulm, 1988). 
TABI,E V

CALCUIATED STATISTICAL PARAMETERS FOR MAGNETITE, QUARTZ, AND BULK SAMPLES FROM THE CAPE BLANCO SHELF

Magnetite

Sample number

$\mathrm{Db}$

SD

$\mathrm{Vx}$

$\mathrm{Tx}$

$\begin{array}{lllll}6708-62 \mathrm{~B} & 108.20 & 27.721 & 2.06 & 4.17 \\ 6708-62 \mathrm{~T} & 108.20 & 29.072 & 2.06 & 4.89 \\ 6708-67 \mathrm{~B} & 111.60 & 29.910 & 2.18 & 4.26 \\ 6708-67 \mathrm{~T} & 103.60 & 25.920 & 1.95 & 3.96 \\ 6708-70 \mathrm{~B} & 127.30 & 39.870 & 2.67 & 4.13 \\ 6708-70 \mathrm{~T} & 127.92 & 34.330 & 2.67 & 3.64\end{array}$

Quartz

Sample number

$\mathrm{Db}$

SD

Vx

$\mathrm{TX}$

$6708-62 B$

192.70

58.532

1.64

1.40

$6708-62 \mathrm{~T}$

244.20

$65.000 \quad 3.21$

1.50

$6708-67 B$

190.40

55.470

2.24

1.43

6708-67T

190.82

44.070

2.24

1. 34

6708-70B

191.30

49.455

2.23

1.46

6708-70T

219.30

53.772

2.74

1. 32 
TABLE V

CALCULATED STATISTICAL PARAMETERS FOR MAGNETITE, QUARTZ, AND BULK SAMPLES FROM CAPE BLANCO SHELF (continued)

Bulk (Opaques and Non-opaques)

Sample number

$\mathrm{Db}$

$S D$

$6708-62 B$

157.80

45.230

$6708-62 \mathrm{~T}$

180.82

58.415

$6708-67 B$

162.50

37.534

$6708-67 \mathrm{~T}$

146.80

32.410

$6708-70 B$

167.96

43.840

6708-70T

145.70

30.625 
In addition, both grain settling velocity $(\mathrm{Vx})$ and critical entrainment shear stress $(T x)$ are calculated (refer to Table V). The results demonstrate approximate settling velocity $(V x)$ equivalence, but widely different shear stress values. These results suggest the potential for a shelf winnowing process (Phillips, 1979), accompanied by local entrainment shear stress, rather than a vertical mixing of a coarser basal placer. The results from the mineral grainsize statistics are important in terms of establishing the possible origins of the continental shelf placers (see discussion).

MICROPROBE ANALYSIS OF SHELF OPAQUE MINERALS

In order to establish mineral economic grade, bulk opaque oxide splits were analyzed using the electron microprobe for approximate relative abundance of the chromium- and titanium- bearing iron oxides. The microprobe analyses of the opaque minerals included the following elements Mg, Al, Cr, Si, Ca, Ti, Mn, Fe, Zn, Co, Ni, Zr, Mo, $\mathrm{V}$ and $\mathrm{Cu}$. Elemental compositions of separate oxide mineral phases, ilmenite, chromite and magnetite from the shelf placers; Mumford, 1991; personal communication). A total of 20 shelf samples were analyzed for opaque oxide chemistry by microprobe. Opaque mineral grains (at least 25 grains per sample) are mounted in epoxy and polished for wave length 
dispersive $\mathrm{x}$-ray analysis of quantitative elemental composition.

Average titanium oxide values of the ilmenite (defined as grains with $>20 \% \mathrm{Ti}$ ) for the shelf samples range from 25.08 to $27.47 \% \mathrm{Ti}$ (Table VI). The highest and lowest mean values of titanium oxide are present in the samples derived from the inner-shelf and mid-shelf areas offshore of the Rogue River. Figure 29 shows the distribution of titanium and iron concentration phases within the ilmenite (averaged) grains as a function of latitude. Trace element contaminants ( $\mathrm{Ca}, \mathrm{Mg}$ and $\mathrm{Mn} ; \mathrm{Figure} \mathrm{30)}$ in the shelf ilmenite grains generally totalled less than $3 \%$. Vanadium elemental concentrations were between 1 and $2 \%$.

The average chromium oxide values of chromite (defined as $>5 \% \mathrm{Cr}$ ) from the shelf samples range from 18 to $29 \% \mathrm{Cr}$ based on the averaged 8 chromite analyses (Table VII). The grains with $10 \%$ chromium oxide are still considered as chromites, although the low chromium grains might actually be chromiferous magnetite. Samples with significant abundances of low chromium (S48 and S51 offshore of the Rogue River) can be split into low chromium-rich oxides $(<20 \% \mathrm{Cr})$ and high chromium oxides $(>20 \% \mathrm{Cr})$ in Figure 31. Contaminants $\mathrm{Al}, \mathrm{Mg}$ are abundant $(>15 \%)$ in the analyzed chromites, while co abundances confira previously suggested trends of increasing Co with increasing $\mathrm{Cr}$ (Figure 32). 
TABLE VI

MICROPROBE ANALYSIS OF AVERAGED ELEMENTAL COMPOSITIONS OF ILMENITE FROM THE SELECTED SHELF PLACER MINERAIS

$\begin{array}{lccccccc} & \text { Sample } & \text { Latitude } & \text { Longitude } & \mathrm{Mg} & \mathrm{Al} & \mathrm{Si} & \mathrm{Ca} \\ 1 & \mathrm{~S} 68 \mathrm{Ti} & 43.440 & 124.410 & 1.079 & 0.015 & 0.021 & 0.037 \\ 2 & \mathrm{~S} 16 \mathrm{Ti} & 42.880 & 124.580 & 1.036 & 0.018 & 0.013 & 0.018 \\ 3 & \mathrm{~S} 17 \mathrm{Ti} & 42.860 & 124.570 & 1.112 & 0.000 & 0.011 & 0.015 \\ 4 & \mathrm{~S} 56 \mathrm{Ti} & 42.580 & 124.410 & 0.942 & 0.005 & 0.010 & 0.021 \\ 5 & \mathrm{~S} 51 \mathrm{Ti} & 42.420 & 124.580 & 1.185 & 0.063 & 0.039 & 0.207 \\ 6 & \mathrm{~S} 48 \mathrm{TTi} & 42.400 & 124.440 & 0.205 & 0.068 & 0.159 & 0.078 \\ 7 & \mathrm{~S} 39 T i & 42.150 & 124.390 & 1.040 & 0.039 & 0.024 & 0.012 \\ 8 & \mathrm{~S} 5 \mathrm{Ti} & 41.590 & 124.310 & 0.666 & 0.016 & 0.019 & 0.059\end{array}$

$\begin{array}{ccccccc} & 0 . & Z n & Z r & \text { Mo } & 0 & \text { Total } \\ 1 & 0.000 & 0.030 & 0.000 & 0.000 & 29.998 & 95.280 \\ 2 & 0.022 & 0.036 & 0.039 & 0.021 & 30.625 & 97.571 \\ 3 & 0.000 & 0.040 & 0.000 & 0.000 & 28.827 & 93.302 \\ 4 & 0.040 & 0.036 & 0.039 & 0.023 & 30.148 & 95.513 \\ 5 & 0.000 & 0.000 & 0.000 & 0.000 & 28.384 & 92.169 \\ 6 & 0.000 & 0.031 & 0.000 & 0.000 & 30.655 & 95.629 \\ 7 & 0.026 & 0.041 & 0.025 & 0.020 & 29.998 & 94.952 \\ 8 & 0.025 & 0.079 & 0.017 & 0.010 & 30.563 & 96.978\end{array}$

$\begin{array}{cccc} & T i & V & C r \\ 1 & 26.307 & 1.638 & 0.045 \\ 2 & 26.716 & 1.673 & 0.038 \\ 3 & 25.977 & 0.000 & 0.039 \\ 4 & 26.792 & 1.652 & 0.048 \\ 5 & 25.084 & 0.000 & 0.026 \\ 6 & 28.364 & 1.901 & 0.024 \\ 7 & 26.779 & 1.472 & 0.043 \\ 8 & 27.469 & 1.531 & 0.04\end{array}$

$M n$
0.952
1.094
1.102
1.194
0.869
1.334
0.604
1.627

$F_{\theta}$
34.976
36.037
36.042
34.378
36.198
32.700
34.645
34.793

$\infty$

$\mathrm{Ni}$

$\begin{array}{ll}0.119 & 0.060 \\ 0.133 & 0.049 \\ 0.039 & 0.078 \\ 0.143 & 0.039 \\ 0.061 & 0.046 \\ 0.039 & 0.068 \\ 0.103 & 0.081 \\ 0.040 & 0.017\end{array}$




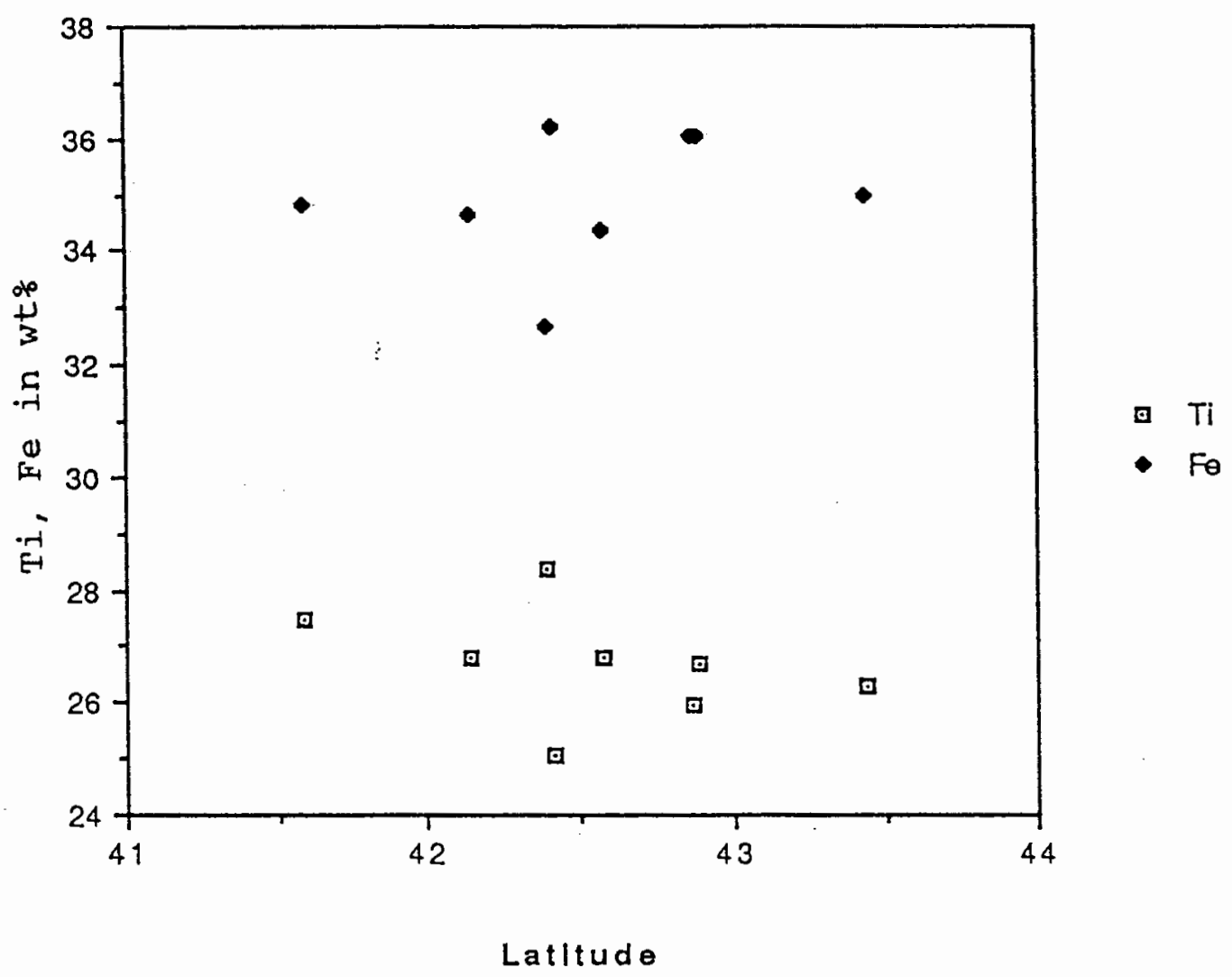

Figure 35. Major Elemental ( $\mathrm{Ti}, \mathrm{Fe}$ ) Distributions in the Ilmenite Phase as a Function of Latitude. 


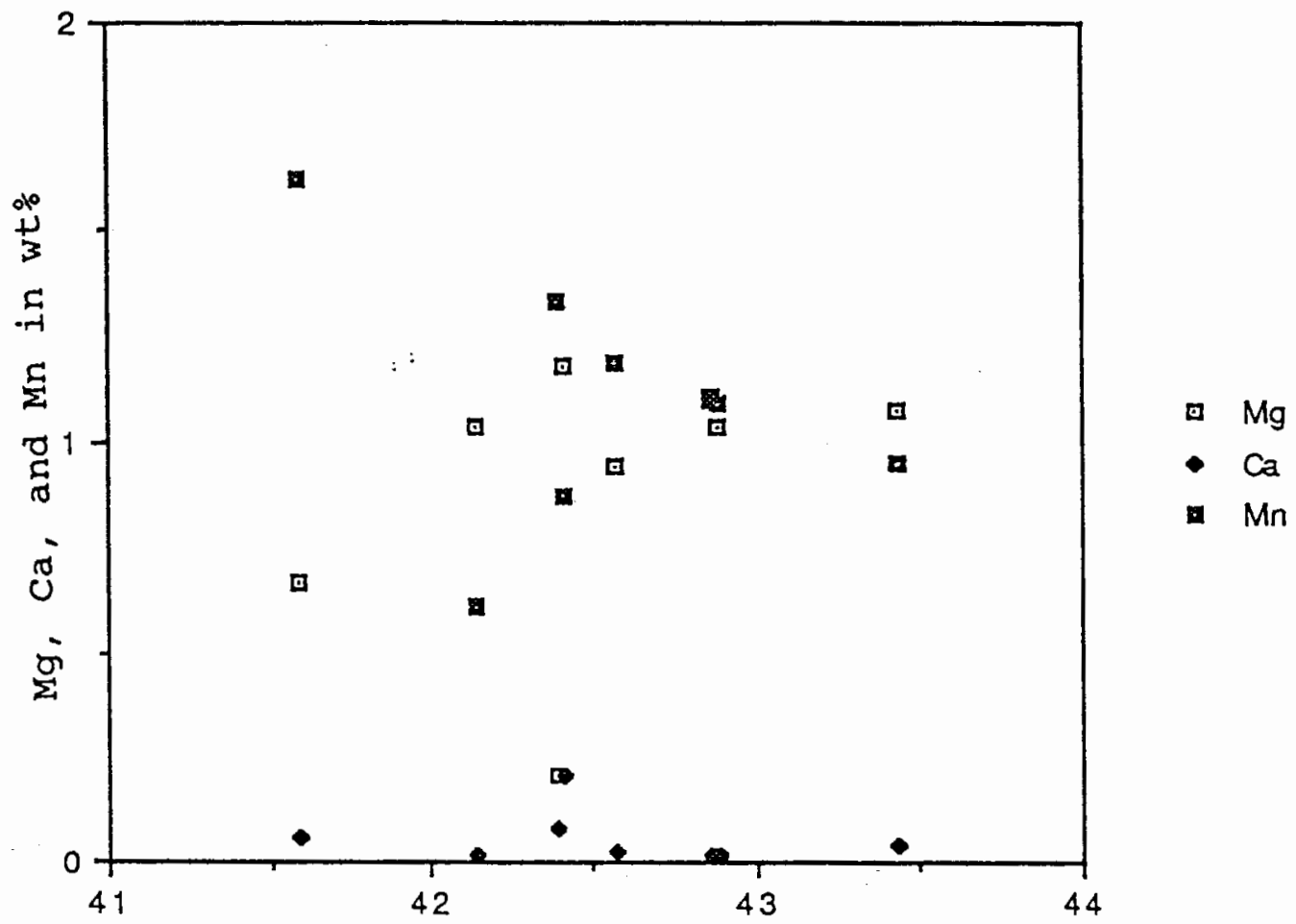

\section{Latitude}

Figure 36. Trace Element contaminants in the Shelf Ilmenite Grains as a Function of Latitude. 
The average iron oxide values of magnetite from the shelf samples range from 60 to $62 \%$ (\%Fe) based on 4 magnetite oxide splits (Table VIII; Figure 33 shows the distribution of $\mathrm{Fe}, \mathrm{Ti}$ as a function of latitude). Relatively high titanium values $(>4 \%)$ indicate the presence of magnetite/titaniferous magnetite phase transitions. Silicate contaminants $V, M n$ and $A l$ in the shelf magnetite grains generally totalled less than $2 \%$. Neither the major or minor elements in the analyzed ilmenite and chromite grains showed regional trends of abundance (north-south) associated with different source rocks over the sampled area. 
TABLE VII

MICROPROBE ANALYSIS OF AVERAGED ELEMENTAL COMPOSITIONS OF CHROMITE FROM THE SELECTED SHELF PLACER MINERALS

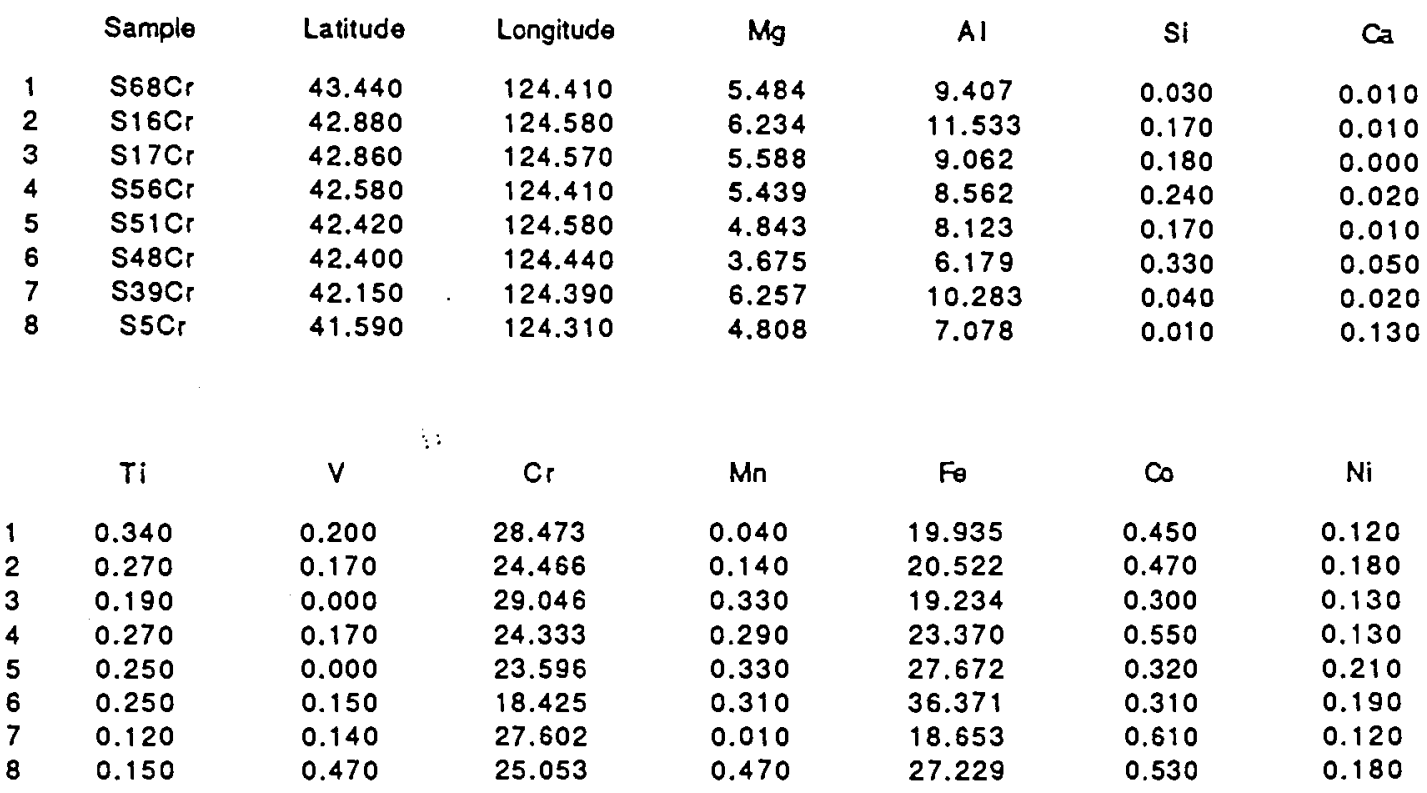

$\begin{array}{cccc} & \text { Zn } & 0 & \text { Total } \\ 1 & 0.170 & 31.000 & 96.100 \\ 2 & 0.230 & 32.000 & 96.800 \\ 3 & 0.240 & 31.000 & 95.600 \\ 4 & 0.230 & 30.000 & 93.700 \\ 5 & 0.130 & 30.000 & 95.500 \\ 6 & 0.220 & 28.000 & 94.200 \\ 7 & 0.180 & 32.000 & 95.900 \\ 8 & 0.290 & 30.000 & 95.900\end{array}$




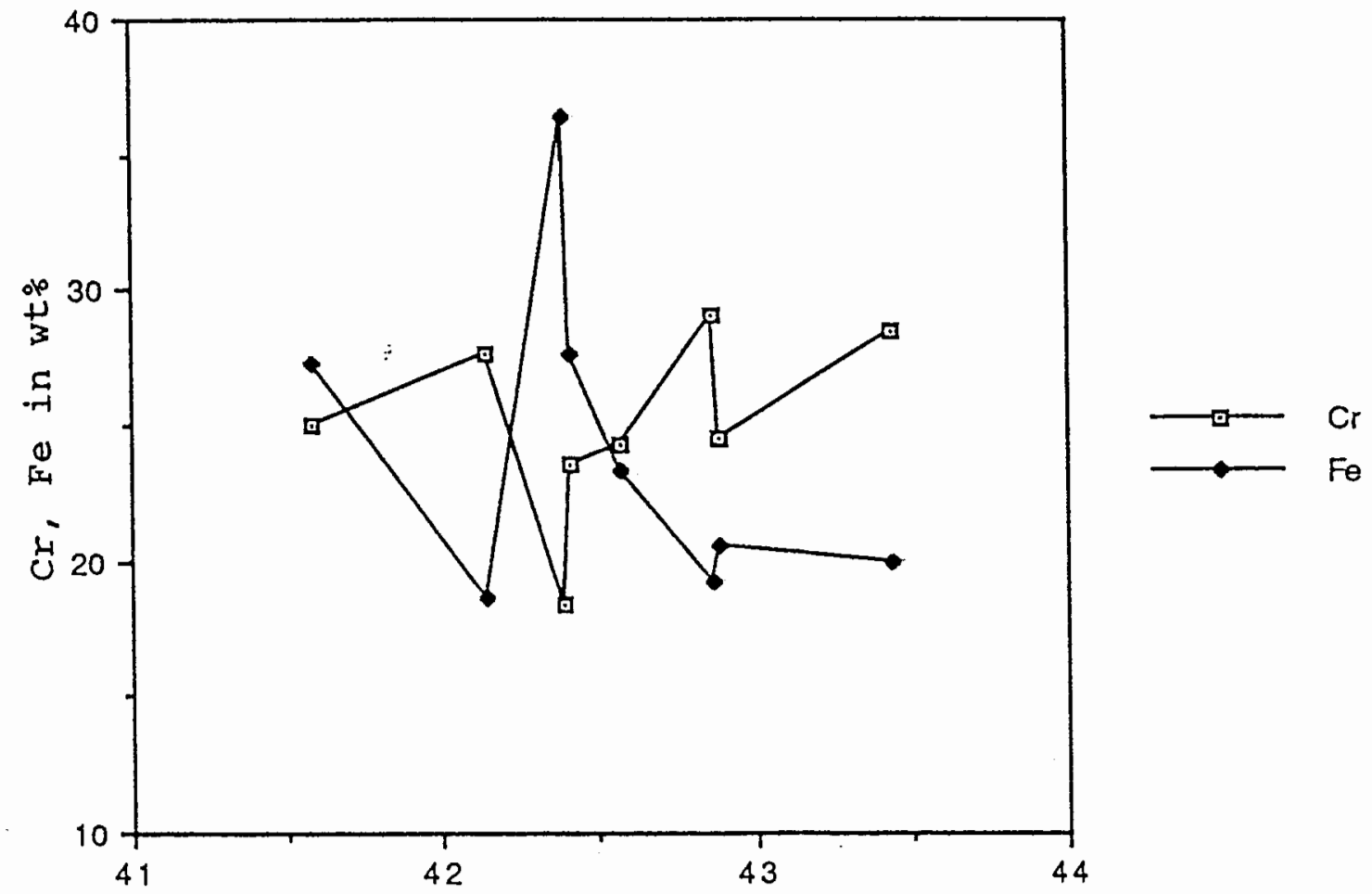

\section{Latltude}

Figure 37. Major Elemental ( $\mathrm{Cr}, \mathrm{Fe}$ ) Distributions in the Chromite Phase as a Function of Latitude. 


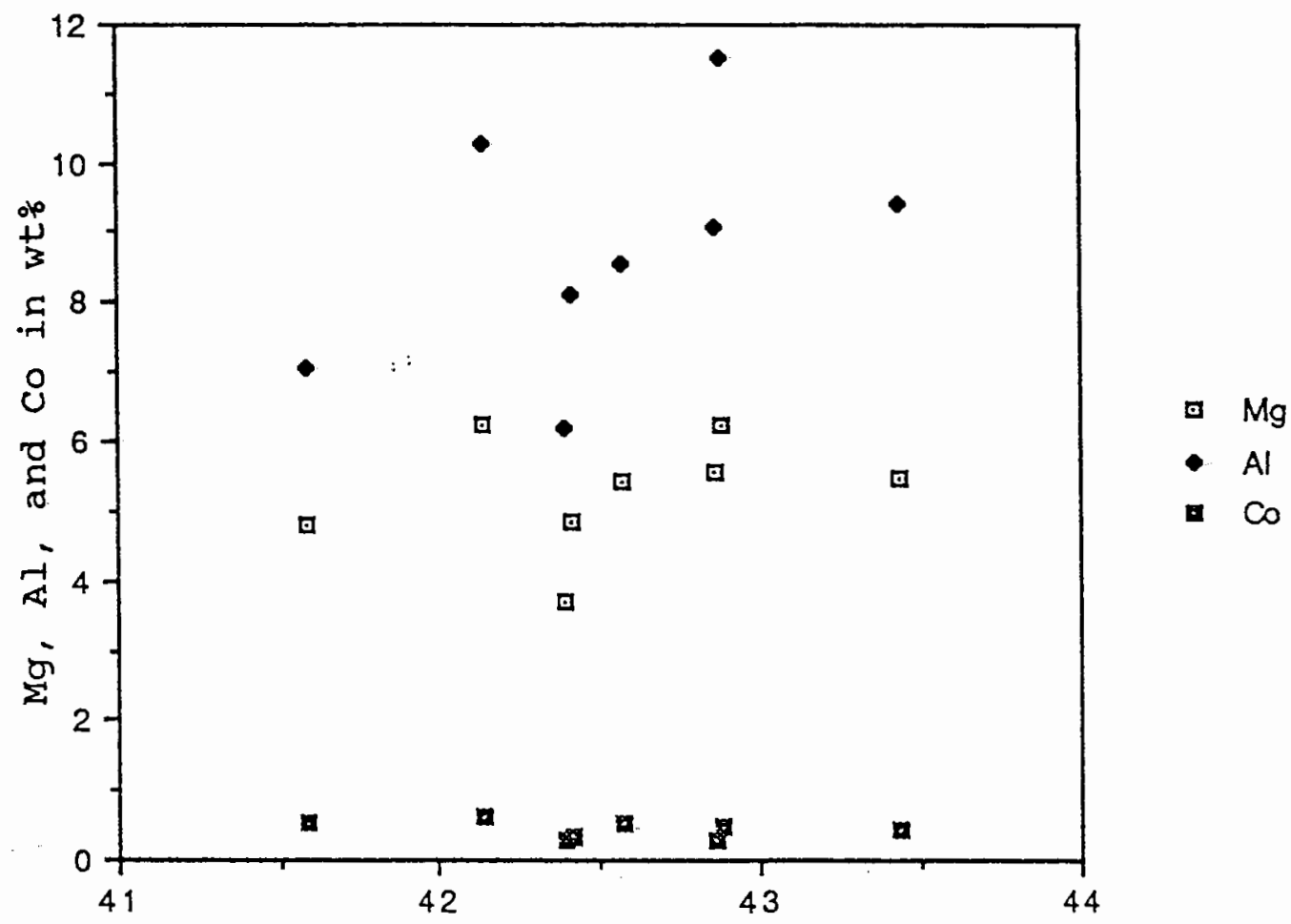

Latlitude

Fiqure 38. Trace Element Contaminants in the shelf chromite Grains as a Function of Latitude. 
MICROPROBE ANALYSIS OF AVERAGED ELEMENTAL COMPOSITONS OF MAGNETITE FROM THE SELECTED SHELF PLACER MINERALS

\begin{tabular}{|c|c|c|c|c|c|c|c|}
\hline & Sample & Latitude & Longitude & $\mathrm{Mg}$ & Al & Si & $\mathrm{Ca}$ \\
\hline 1 & S68Mag & 43.440 & 124.41 & 0.46 & 0.59 & 0.06 & 0.157 \\
\hline 2 & S17Mag & 42.860 & 124.57 & 0.42 & 0.47 & 0.05 & 0.021 \\
\hline 3 & S51Mag & 42.420 & 124.58 & 0.86 & 0.81 & 0.11 & 0.015 \\
\hline 4 & S48Mag & 42.400 & 124.44 & 0.68 & 0.85 & 0.24 & 0.037 \\
\hline & $\mathrm{Ti}$ & v & $\mathrm{Cr}$ & $M n$ & $F_{\theta}$ & $\infty$ & $\mathrm{Ni}$ \\
\hline 1 & 4.820 & $0.650:$ & 0.123 & 0.300 & 60.107 & 0.141 & 0.073 \\
\hline 2 & 4.638 & $0.000^{\circ}$ & 0.306 & 0.160 & 61.478 & 0.129 & 0.138 \\
\hline 3 & 3.625 & 0.000 & 0.120 & 0.290 & 62.295 & 0.100 & 0.122 \\
\hline 4 & 1.886 & 0.430 & 0.276 & 0.160 & 62.638 & 0.117 & 0.107 \\
\hline
\end{tabular}

$\begin{array}{cccc} & \text { Zn } & 0 & \text { Total } \\ 1 & 0.073 & 22.065 & 94.417 \\ 2 & 0.049 & 21.736 & 89.417 \\ 3 & 0.039 & 21.892 & 90.275 \\ 4 & 1.598 & 21.659 & 89.249\end{array}$


86

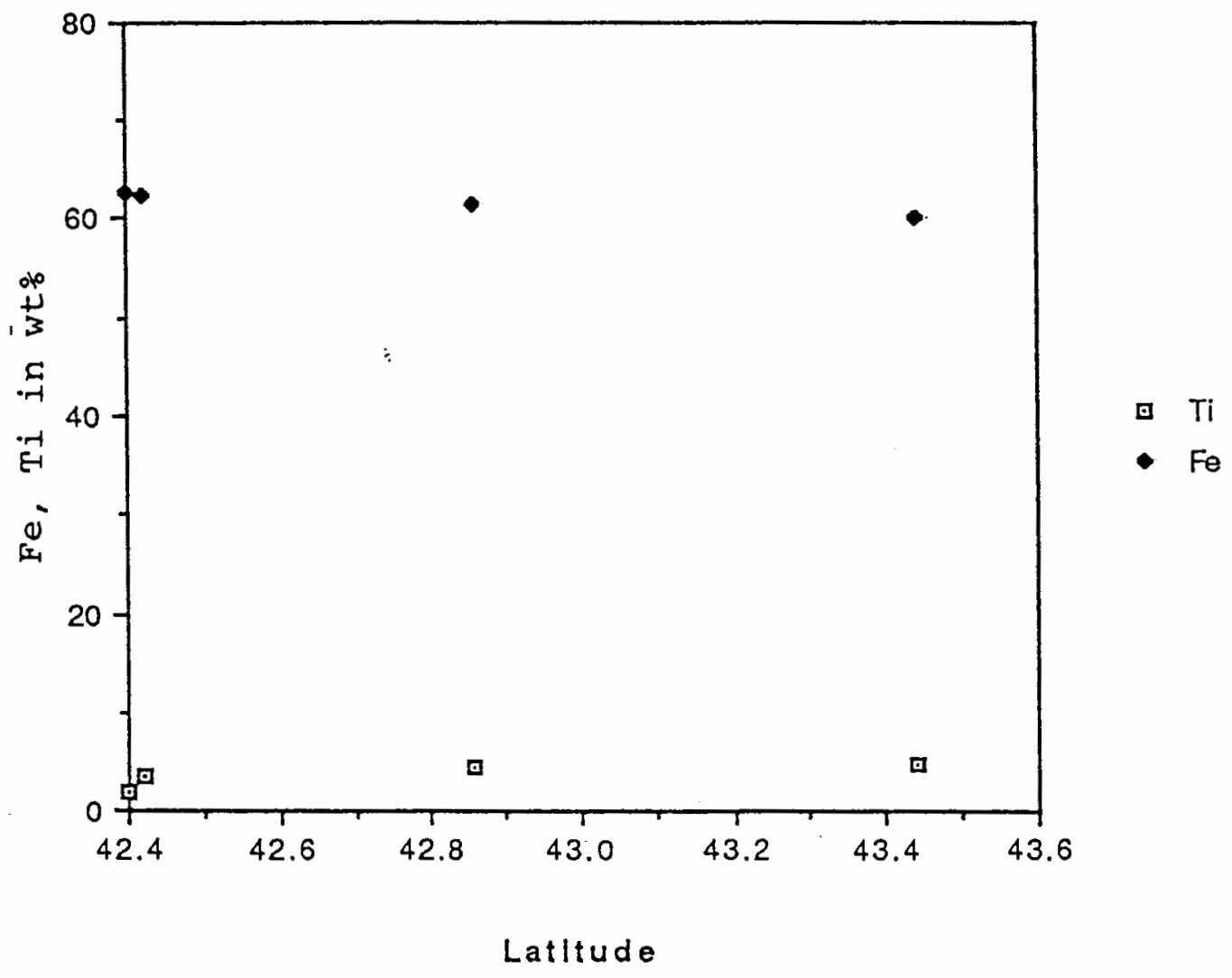

Figure 39. Major Elemental (Fe, Ti),

Distributions in the Magnetite Phase as a Function of Latitude. 
CHAPTER VII

DISCUSSION

SHELF OPAQUE DISPERSAL PATTERNS (Q-MODE FACTOR ANALYSIS)

In order to establish shelf opaque oxide dispersal patterns elemental compositions (INAA analysis) of 125 opaque mineral splits from the oregon shelf, river, and beach sites have been analyzed by multivariate analysis. Qmode factor analysis was performed on the compositional data using the extended CABFAC program to identify potential endmember sources (Klovan and Meisch, 1976). Element abundances were normalized by their corresponding range of values so that major and trace elements are not underrepresented in the factor analysis. Multivariate (Qmode) was performed on the shelf opaque oxide geochemical data, as well as on a combined shelf-beach-river data set. Table IX shows the general statistics of the opaque oxide compositions, including the average relative abundances of 21 various elements. Analysis of the combined shelf-riverbeach data set yielded four factors accounting for $99 \%$ of 
TABLE IX

GENERAL STATISTICS FOR ELEMENT ABUNDANCES IN SHELF OPAQUE SEPARATES

$\begin{array}{rccccc} & \text { VARIABLE } & \text { AVERAGE } & \begin{array}{c}\text { STANDARO } \\ \text { DEVIATION }\end{array} & \begin{array}{c}\text { MINIMUM } \\ \text { VALUE }\end{array} & \begin{array}{c}\text { MAXIMUM } \\ \text { VALUE }\end{array} \\ 1 & & & & & \\ 2 & \mathrm{Na} & 1753.85 & 1131.58 & 205.00 & 4980.20 \\ 3 & \mathrm{Mg} & 46987.34 & 25648.04 & 3500.00 & 144350.00 \\ 4 & \mathrm{Al} & 20145.96 & 7157.06 & 2364.00 & 38053.00 \\ 5 & \mathrm{Ca} & 21045.86 & 14341.98 & 1821.00 & 72635.00 \\ 6 & \mathrm{Sc} & 47.96 & 17.76 & 3.80 & 76.70 \\ 7 & \mathrm{Ti} & 101940.55 & 66757.67 & 110804.00 & 266139.00 \\ 8 & \mathrm{~V} & 1468.70 & 1288.20 & 520.80 & 15150.00 \\ 9 & \mathrm{Cr} & 27319.36 & 26798.33 & 606.00 & 129498.00 \\ 10 & \mathrm{Mn} & 6373.38 & 2526.22 & 2560.40 & 16787.40 \\ 11 & \mathrm{Fe} & 344806.88 & 61305.32 & 192957.00 & 510830.00 \\ 12 & \mathrm{CO} & 123.84 & 54.04 & 42.90 & 366.90 \\ 13 & \mathrm{As} & 6.47 & 4.08 & 1.66 & 38.56 \\ 14 & \mathrm{SO} & 1.19 & 0.77 & 0.23 & 5.61 \\ 15 & \mathrm{La} & 13.55 & 9.14 & 1.36 & 55.97 \\ 16 & \mathrm{Co} & 25.26 & 17.93 & 3.66 & 112.67 \\ 17 & \mathrm{Sm} & 2.94 & 1.62 & 0.48 & 9.59 \\ 18 & \mathrm{E} & 0.70 & 0.37 & 0.09 & 1.84 \\ 19 & \mathrm{Yo} & 4.39 & 3.73 & 0.41 & 23.42 \\ 20 & \mathrm{Lu} & 0.78 & 1.01 & 0.09 & 9.57 \\ 21 & \mathrm{HI} & 8.94 & 6.74 & 0.66 & 29.60 \\ 22 & \mathrm{Ta} & 8.31 & 6.98 & 0.31 & 30.82\end{array}$


the element composition variance. Initial model runs based on additional factors did not produce significantly different results from the four factor models. The specific element contributions (factor scores) to the four factors are presented in Table $\mathrm{X}$.

The sample factor scores and factor loadings for the combined onshore/offshore data set are presented in Table XI. The first factor (28.8\% of the variance) contains high scores for $\mathrm{Cr}, \mathrm{Al}, \mathrm{Co}, \mathrm{Fe}$ and $\mathrm{Sb}$. The second factor $(33.4 \%$ of the variance) includes high scores for $\mathrm{Ti}, \mathrm{Hf}, \mathrm{Sc}, \mathrm{Ta}$ and Fe. The third factor ( $14.3 \%$ of the variance) contains high scores for $\mathrm{Na}, \mathrm{Mg}, \mathrm{Al}, \mathrm{Ca}$ and $\mathrm{Sc}$. The fourth factor (19.7\% of the variance) includes high scores for $\mathrm{Na}$, and LREE- La, $\mathrm{Ce}, \mathrm{Sm}$ and $\mathrm{Eu}$ (light rare earth-elements).

The factor loadings are plotted as a function of sample latitude to portray the regional variation in the contribution of each end-member source (dispersal patterns on the shelf). The first factor shows maximum loadings south of $43^{\circ}$ and probably represents a Klamath Mountain source, because it is uniquely enriched in $\mathrm{Cr}, \mathrm{Co}, \mathrm{Al}$ and $\mathrm{Sb}$ (Figure 34). The second factor shows maximum loadings between $42.50^{\circ}$ and $45.50^{\circ}$ and it is uniquely enriched in $\mathrm{Ti}$, Hf, Sc and Ta (Figure 41), and probably represents a coast Range source. The second factor loadings in northern oregon reach a minimum at $46^{\circ}$, reflecting the dilution to the north by the continental Columbia River drainage which supplies 
ELEMENT FACTOR SCORES FOR THE COMBINED RIVER, BEACH, AND SHELF SAMPLE SET

\begin{tabular}{|c|c|c|c|c|c|c|c|}
\hline & Sample & Latllude & Longitude & Faclor 1 & Factor 2 & Factor 3 & Factor 4 \\
\hline 1 & $S \cdot i$ & 41.00 & 124.18 & 0.330 & 0.201 & 0.605 & 0.559 \\
\hline 2 & $s-2$ & 41.20 & 124.18 & 0.609 & 0.487 & 0.417 & 0.406 \\
\hline 3 & $S \cdot 3$ & 41.42 & 124.17 & 0.476 & 0.226 & 0.725 & 0.421 \\
\hline 4 & S. 4 & 41.59 & 124.36 & 0.491 & 0.205 & 0.766 & 0.345 \\
\hline 5 & S.5 & 41.59 & 124.31 & 0.537 & 0.231 & 0.736 & 0.313 \\
\hline 6 & S-6 & 41.59 & 124.16 & 0.551 & 0.228 & 0.734 & 0.305 \\
\hline 7 & $5-7$ & 42.08 & 124.39 & 0.379 & 0.196 & 0.804 & 0.379 \\
\hline 8 & $S+8$ & 42.29 & 124.50 & 0.394 & 0.840 & 0.233 & 0.269 \\
\hline 9 & S.9 & 42.28 & 124.43 & 0.828 & 0.367 & 0.307 & 0.272 \\
\hline 10 & S-10 & 42.58 & 124.41 & 0.580 & 0.324 & 0.579 & 0.455 \\
\hline 11 & S.11 & 42.56 & 124.38 & 0.560 & 0.269 & 0.621 & 0.445 \\
\hline 12 & $S-12$ & 42.57 & 124.55 & 0.535 & 0.283 & 0.594 & 0.508 \\
\hline 13 & $5 \cdot 13$ & 42.57 & 124.48 & 0.565 & 0.260 & 0.644 & 0.425 \\
\hline 14 & S- 14 & 42.53 & 124.71 & 0.522 & 0.431 & 0.531 & 0.498 \\
\hline 15 & S.15 & $42.87^{\circ}$ & 124.61 & 0.346 & 0.867 & 0.231 & 0.239 \\
\hline 16 & $S .16$ & 42.88 & 124.58 & 0.388 & 0.857 & 0.239 & 0.219 \\
\hline 17 & 5.17 & 42.86 & 124.57 & 0.452 & 0.840 & 0.225 & 0.183 \\
\hline 18 & S.18 & 43.16 & 124.70 & 0.471 & 0.480 & 0.567 & 0.463 \\
\hline 19 & 5.19 & 43.20 & 124.45 & 0.483 & 0.726 & 0.280 & 0.390 \\
\hline 20 & $S-20$ & 43.35 & 124.41 & 0.532 & 0.649 & 0.355 & 0.403 \\
\hline 21 & $S-21$ & 43.56 & 124.51 & 0.485 & 0.516 & 0.477 & 0.515 \\
\hline 22 & $S \cdot 22$ & 43.56 & 124.37 & 0.458 & 0.587 & 0.404 & 0.524 \\
\hline 23 & $S .23$ & 43.56 & 124.14 & 0.298 & 0.813 & 0.288 & 0.383 \\
\hline 24 & $S \cdot 24$ & 44.20 & 124.41 & 0.321 & 0.650 & 0.425 & 0.498 \\
\hline 25 & $S-25$ & 44.39 & 124.50 & 0.422 & 0.652 & 0.408 & 0.472 \\
\hline 26 & $S-26$ & 44.38 & 124.27 & 0.304 & 0.762 & 0.262 & 0.472 \\
\hline 27 & $S .27$ & 44.58 & 124.17 & 0.244 & 0.937 & 0.146 & 0.177 \\
\hline 28 & $S \cdot 28$ & 45.11 & 124.22 & 0.389 & 0.564 & 0.379 & 0.613 \\
\hline 29 & $S-29$ & 45.35 & 124.40 & 0.334 & 0.553 & 0.390 & 0.643 \\
\hline 30 & $S-30$ & 45.35 & 124.26 & 0.330 & 0.605 & 0.331 & 0.640 \\
\hline 31 & $S .31$ & 45.35 & 124.12 & 0.307 & 0.628 & 0.353 & 0.609 \\
\hline 32 & $S-32$ & 45.35 & 123.97 & 0.277 & 0.764 & 0.341 & 0.448 \\
\hline 33 & $S-33$ & 45.56 & 124.28 & 0.292 & 0.415 & 0.246 & 0.806 \\
\hline 34 & $S-34$ & 46.20 & 124.26 & 0.329 & 0.556 & 0.196 & 0.719 \\
\hline 35 & S.35 & 46.20 & 124.29 & 0.205 & 0.383 & 0.255 & 0.844 \\
\hline 36 & S.37 & 42.10 & 124.37 & 0.787 & 0.331 & 0.436 & 0.268 \\
\hline 37 & $S-38$ & 42.15 & 124.39 & 0.428 & 0.249 & 0.776 & 0.370 \\
\hline 38 & S-39 & 42.15 & 124.37 & 0.873 & 0.381 & 0.167 & 0.204 \\
\hline 39 & 5.40 & 42.21 & 124.41 & 0.692 & 0.286 & 0.344 & 0.264 \\
\hline 40 & $S .41$ & 42.35 & 124.44 & 0.828 & 0.350 & 0.347 & 0.261 \\
\hline 41 & 5.43 & 42.35 & 124.46 & 0.777 & 0.306 & 0.439 & 0.321 \\
\hline 42 & $S .44$ & 42.36 & 124.46 & 0.780 & 0.323 & 0.437 & 0.303 \\
\hline 43 & $S-45$ & 42.39 & 124.46 & 0.810 & 0.326 & 0.358 & 0.305 \\
\hline 44 & $S .46$ & 42.39 & 124.56 & 0.678 & 0.347 & 0.464 & 0.424 \\
\hline 45 & $5-47$ & 42.23 & 124.56 & 0.580 & 0.409 & 0.405 & 0.410 \\
\hline 46 & $S .48$ & 42.40 & 124.44 & 0.677 & 0.311 & 0.535 & 0.386 \\
\hline 47 & 5.49 & 42.40 & 124.44 & 0.684 & 0.339 & 0.441 & 0.460 \\
\hline 48 & $S .50$ & 42.42 & 124.58 & 0.675 & 0.327 & 0.469 & 0.441 \\
\hline 49 & S.51 & 42.42 & -124.54 & 0.656 & 0.381 & 0.403 & 0.465 \\
\hline 50 & $S .52$ & 42.25 & 124.54 & 0.648 & 0.361 & 0.446 & 0.469 \\
\hline 51 & $S .53$ & 42.47 & 124.65 & 0.575 & 0.338 & 0.531 & 0.510 \\
\hline 52 & S.54 & 42.47 & 124.65 & 0.615 & 0.353 & 0.485 & 0.506 \\
\hline 53 & $S .55$ & 42.57 & 124.48 & 0.685 & 0.146 & 0.492 & 0.455 \\
\hline 54 & $S .56$ & 42.58 & 124.41 & 0.595 & 0.298 & 0.596 & 0.428 \\
\hline 55 & S.57 & 42.38 & 124.55 & 0.559 & 0.328 & 0.515 & 0.551 \\
\hline 56 & 5.58 & 42.38 & 124.42 & 0.743 & 0.462 & 0.323 & 0.265 \\
\hline
\end{tabular}


ELEMENT FACTOR SCORES FOR THE COMBINED RIVER, BEACH, AND SHELF SAMPLE SET

(continued)

\begin{tabular}{|c|c|c|c|c|c|c|c|}
\hline & Sample & Latitudo & Longitude & Factor 1 & Factor 2 & Factor 3 & Factor 4 \\
\hline 57 & S.59 & .42 .41 & 124.33 & 0.501 & 0.586 & 0.384 & 0.501 \\
\hline 58 & s.60 & 42.44 & 124.66 & 0.524 & 0.595 & 0.394 & 0.453 \\
\hline 59 & $S-61$ & 42.76 & 124.56 & 0.392 & 0.815 & 0.255 & 0.307 \\
\hline 60 & S.62 & 43.11 & 124.68 & 0.522 & 0.608 & 0.427 & 0.408 \\
\hline 61 & S.63 & 43.11 & 124.48 & 0.317 & 0.706 & 0.202 & 0.548 \\
\hline 62 & 5.65 & 43.12 & 124.43 & 0.403 & 0.802 & 0.219 & 0.343 \\
\hline 63 & 5.66 & 43.29 & 124.59 & 0.549 & 0.317 & 0.486 & 0.594 \\
\hline 64 & S.67 & 43.35 & 124.28 & 0.429 & 0.454 & 0.421 & 0.645 \\
\hline 65 & 5.68 & 43.44 & 124.41 & 0.369 & 0.689 & 0.253 & 0.551 \\
\hline 66 & S.69 & 44.20 & 124.14 & 0.297 & 0.870 & 0.172 & 0.283 \\
\hline 67 & S.70 & 44.59 & 124.47 & 0.430 & 0.474 & 0.400 & 0.622 \\
\hline 68 & 5.71 & 44.59 & 124.20 & 0.337 & 0.641 & 0.313 & 0.592 \\
\hline 69 & 5.72 & 44.59 & 124.05 & 0.234 & 0.944 & 0.141 & 0.175 \\
\hline 70 & $S-73$ & $45: 14$ & 124.99 & 0.226 & 0.935 & 0.152 & 0.210 \\
\hline 71 & OR-1 & 43.41 & 124.54 & 0.500 & 0.591 & 0.387 & 0.492 \\
\hline 72 & OR.2 & 43.50 & 124.20 & 0.304 . & 0.655 & 0.385 & 0.563 \\
\hline 73 & OR-3 & 44.05 & 124.16 & 0.273 & 0.876 & 0.185 & 0.322 \\
\hline 74 & $O R \cdot 4$ & 44.05 & 124.43 & 0.400 & 0.760 & 0.314 & 0.389 \\
\hline 75 & OR-5 & 44.72 & 124.10 & 0.279 & 0.701 & 0.382 & 0.496 \\
\hline 76 & OR-6 & 44.72 & 124.24 & 0.266 & 0.790 & 0.212 & 0.488 \\
\hline 77 & OR.7 & 44.72 & 124.38 & 0.346 & 0.618 & 0.454 & 0.534 \\
\hline 78 & $O R \cdot 7 A$ & 45.20 & 124.02 & 0.263 & 0.896 & 0.188 & 0.285 \\
\hline 79 & OR.8 & 45.29 & 124.01 & 0.296 & 0.667 & 0.391 & 0.547 \\
\hline 80 & OR-9 & 45.29 & 124.09 & 0.277 & 0.807 & 0.234 & 0.459 \\
\hline 81 & OR-1O & 45.29 & 123.99 & 0.301 & 0.672 & 0.335 & 0.575 \\
\hline 82 & OR-11 & 45.29 & 124.06 & 0.262 & 0.414 & 0.417 & 0.751 \\
\hline 83 & OR-12 & 45.47 & 124.21 & 0.312 & 0.482 & 0.341 & 0.740 \\
\hline 84 & OR-13 & 45.47 & 124.42 & 0.244 & 0.624 & 0.211 & 0.672 \\
\hline 85 & OR-14 & 45.53 & 123.99 & 0.297 & 0.721 & 0.337 & 0.517 \\
\hline 86 & OR.15 & 45.56 & 124.07 & 0.278 & 0.472 & 0.320 & 0.763 \\
\hline 87 & OR-16 & 46.02 & 124.05 & 0.327 & 0.512 & 0.339 & 0.708 \\
\hline 88 & 3.11 & 40.70 & 124.20 & 0,829 & 0.344 & 0.176 & 0.234 \\
\hline 89 & B.12 & 41.04 & 124.08 & 0.704 & 0.527 & 0.214 & 0.324 \\
\hline 90 & B-13 & 41.36 & 124.06 & 0.771 & 0.440 & 0.231 & 0.313 \\
\hline 91 & B.1 4 & 41.47 & 124.07 & 0.826 & 0.458 & 0.053 & 0.235 \\
\hline 92 & 8.15 & 41.73 & 124.16 & 0.849 & 0.410 & 0.242 & 0.140 \\
\hline 93 & 8.16 & 41.86 & 124.13 & 0.800 & 0.312 & 0.413 & 0.220 \\
\hline 94 & B-17 & 42.02 & 124.16 & 0.914 & 0.281 & 0.130 & 0.156 \\
\hline 95 & TB.3 & 42.32 & 124.24 & 0.894 & 0.365 & 0.072 & 0.166 \\
\hline 96 & $B \cdot 18$ & 42.37 & 124.24 & 0.876 & 0.329 & 0.234 & 0.201 \\
\hline 97 & B.19 & 42.50 & 124.22 & 0.882 & 0.342 & 0.170 & 0.172 \\
\hline 98 & TB.8 & 42.73 & 124.26 & 0.408 & 0.830 & 0.172 & 0.244 \\
\hline 99 & 8.20 & 42.84 & 124.30 & 0.608 & 0.732 & 0.157 & 0.167 \\
\hline 100 & 8.21 & 43.21 & 124.20 & 0.440 & 0.837 & 0.149 & 0.192 \\
\hline 101 & B.22 & 44.03 & 124.10 & 0.225 & 0.887 & 0.078 & 0.221 \\
\hline 102 & 8.23 & 44.67 & 124.04 & 0.254 & 0.934 & 0.125 & 0.095 \\
\hline 103 & B.24 & 45.01 & 124.04 & 0.206 & 0.957 & 0.157 & 0.077 \\
\hline 104 & T8.5 & 45.31 & 124.02 & 0.324 & 0.864 & 0.085 & 0.203 \\
\hline 105 & TB-4 & 45.72 & 123.59 & 0.347 & 0.811 & 0.028 & 0.152 \\
\hline 106 & 8.25 & 45.91 & 123.58 & 0.420 & 0.797 & 0.131 & 0.327 \\
\hline 107 & 8.26 & 46.22 & 124.00 & 0.458 & 0.579 & 0.204 & 0.581 \\
\hline 108 & R-11 & 40,62 & 124.14 & 0.716 & 0.286 & 0.381 & 0.469 \\
\hline 109 & R.12 & 40.93 & 124.05 & 0.828 & 0.304 & 0.164 & 0.287 \\
\hline 110 & R-13 & 41.54 & 124.04 & 0.884 & 0.327 & 0.194 & 0.243 \\
\hline 111 & $8=14$ & 41.93 & 124.10 & 0.905 & 0.128 & 0.247 & 0.119 \\
\hline 112 & $R=15$ & 42.05 & 124.15 & 0.451 & 0.246 & 0.803 & 0.243 \\
\hline
\end{tabular}


ELEMENT FACTOR SCORES FOR THE COMBINED RIVER, BEACH, AND SHELF SAMPLE SET

(continued)

\begin{tabular}{|c|c|c|c|c|c|c|c|}
\hline & Sample & Latitude & Longitude & Factor 1 & Faclop 2 & Faclor 3 & Factor 4 \\
\hline 113 & $R \cdot 16$ & 42.27 & 124.25 & 0.798 & 0.183 & 0.209 & 0.443 \\
\hline 114 & R.17 & 42.42 & 124.20 & 0.813 & 0.359 & 0.302 & 0.315 \\
\hline 115 & R.18 & 42.79 & 124.28 & 0.578 & 0.320 & 0.276 & 0.648 \\
\hline 116 & $R \cdot 19$ & 42.85 & 124.30 & 0.883 & 0.218 & 0.210 & 0.217 \\
\hline 117 & $R \cdot 20$ & 43.12 & 124.22 & 0.576 & 0.622 & 0.236 & 0.358 \\
\hline 118 & R.21 & 43.67 & 124.02 & 0.423 & 0.590 & 0.288 & 0.603 \\
\hline 119 & $R \cdot 22$ & 44.01 & 123.58 & 0.202 & 0.924 & 0.045 & 0.297 \\
\hline 120 & $R \cdot 23$ & 44.42 & 123.59 & 0.211 & 0.913 & 0.138 & 0.289 \\
\hline 121 & R.24 & 44.92 & 124.00 & 0.155 & 0.949 & 0.115 & 0.115 \\
\hline 122 & R.25 & 45.15 & 123.58 & 0.309 & 0.585 & 0.245 & 0.640 \\
\hline 123 & $R \cdot 26$ & 45.45 & 123.47 & 0.255 & 0.461 & 0.421 & 0.681 \\
\hline 124 & $R \cdot 27$ & 45.65 & 123.51 & 0.366 & 0.560 & 0.346 & 0.611 \\
\hline 125 & $R \cdot 28$ & 46.25 & 123.58 & 0.334 & 0.403 & 0.262 & 0.623 \\
\hline
\end{tabular}


FACTOR LOADINGS FOR FOUR FACTORS OF ELEMENTAL COMPOSITION

\begin{tabular}{|c|c|c|c|c|c|}
\hline & VARIABLE & 1 & 2 & 3 & 4 \\
\hline 1 & $\mathrm{Na}$ & -0.237 & .0 .348 & 1.114 & 2.052 \\
\hline 2 & $\mathrm{Mg}$ & 0.469 & .0 .198 & 2.543 & -0.281 \\
\hline 3 & AI & 1.972 & -0.254 & 1.172 & 0.433 \\
\hline 4 & $\mathrm{Ca}$ & -0.162 & .0 .255 & 2.620 & 0.218 \\
\hline 5 & Sc & -0.314 & 2.220 & 1.806 & .0 .099 \\
\hline 6 & $T i$ & .0 .188 & 2.241 & -0.140 & .0 .224 \\
\hline 7 & $v$ & 0.435 & 0.101 & -0.092 & 0.051 \\
\hline 8 & $\mathrm{Cr}$ & 2.118 & .0 .256 & .0 .440 & .0 .444 \\
\hline 9 & $M n$ & 0.652 & 1.236 & -0.039 & 0.032 \\
\hline 10 & $\mathrm{Fe}_{\theta}$ & 2.632 & 1.036 & -0.473 & 0.276 \\
\hline 11 & Co & 2.055 & -0.014 & .0 .177 & .0 .090 \\
\hline 12 & As & 0.194 & -0.042 & 0.341 & 0.590 \\
\hline 13 & S & 0.165 & 0.127 & 0.277 & 0.736 \\
\hline 14 & La & .0 .137 & 0.362 & .0 .627 & 1.672 \\
\hline 15 & Co & -0.074 & 0.192 & .0 .600 & 1.689 \\
\hline 16 & Sm & .0 .075 & 0.167 & -0.286 & 1.996 \\
\hline 17 & Es & 0.134 & .0 .024 & -0.152 & 2.357 \\
\hline 18 & Yo & -0.223 & 0.993 & 0.056 & 0.049 \\
\hline 19 & Lu & -0.105 & 0.376 & .0 .102 & 0.187 \\
\hline 20 & HI & -0.098 & 1.827 & -0.494 & .0 .035 \\
\hline 21 & $\mathrm{Ta}$ & .0 .492 & 1.845 & -0.084 & .0 .124 \\
\hline 22 & & & & & \\
\hline 23 & VARIANCE & 28.774 & 33.417 & 14.335 & 19.679 \\
\hline
\end{tabular}

Total variance $=96.205$ 


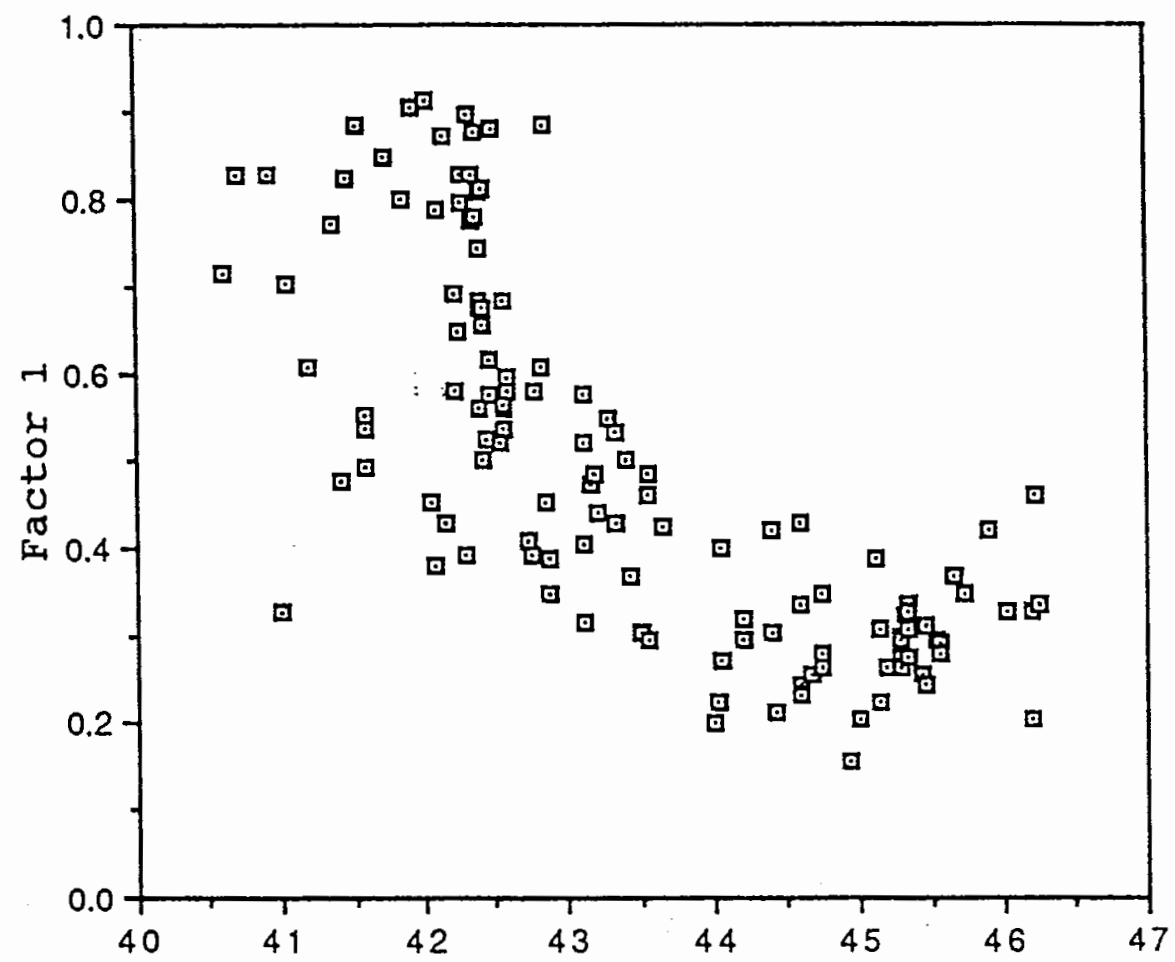

a Factor 1

\section{Latitude}

Figure 40. Plot of Combined Shelf and Onshore Factor 1 Loadings as a Function of Latitude. 


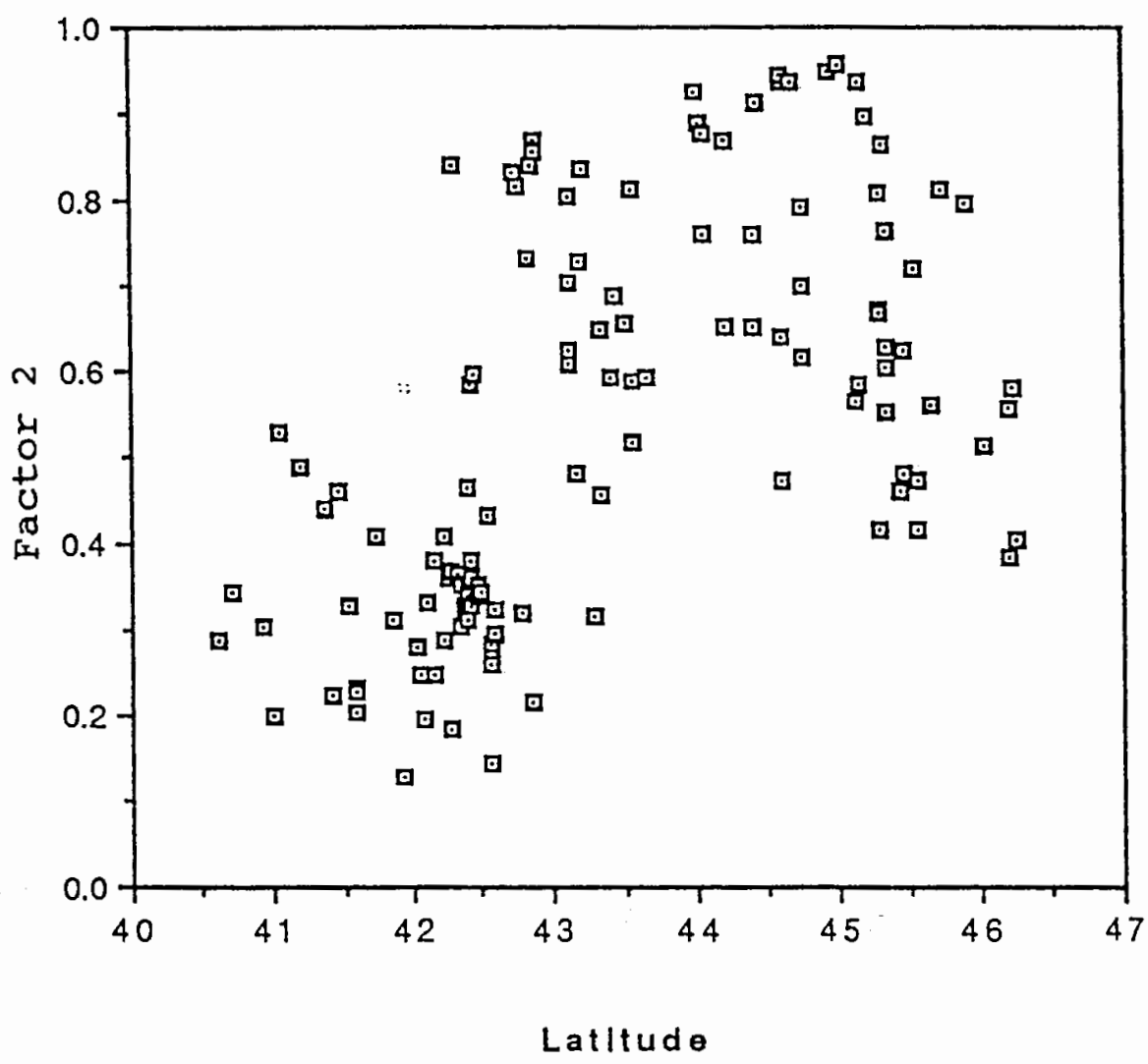

घ Factor 2

Figure 41. Plot of Combined Shelf and onshore Factor 2 Loadings as a Function of Latitude. 


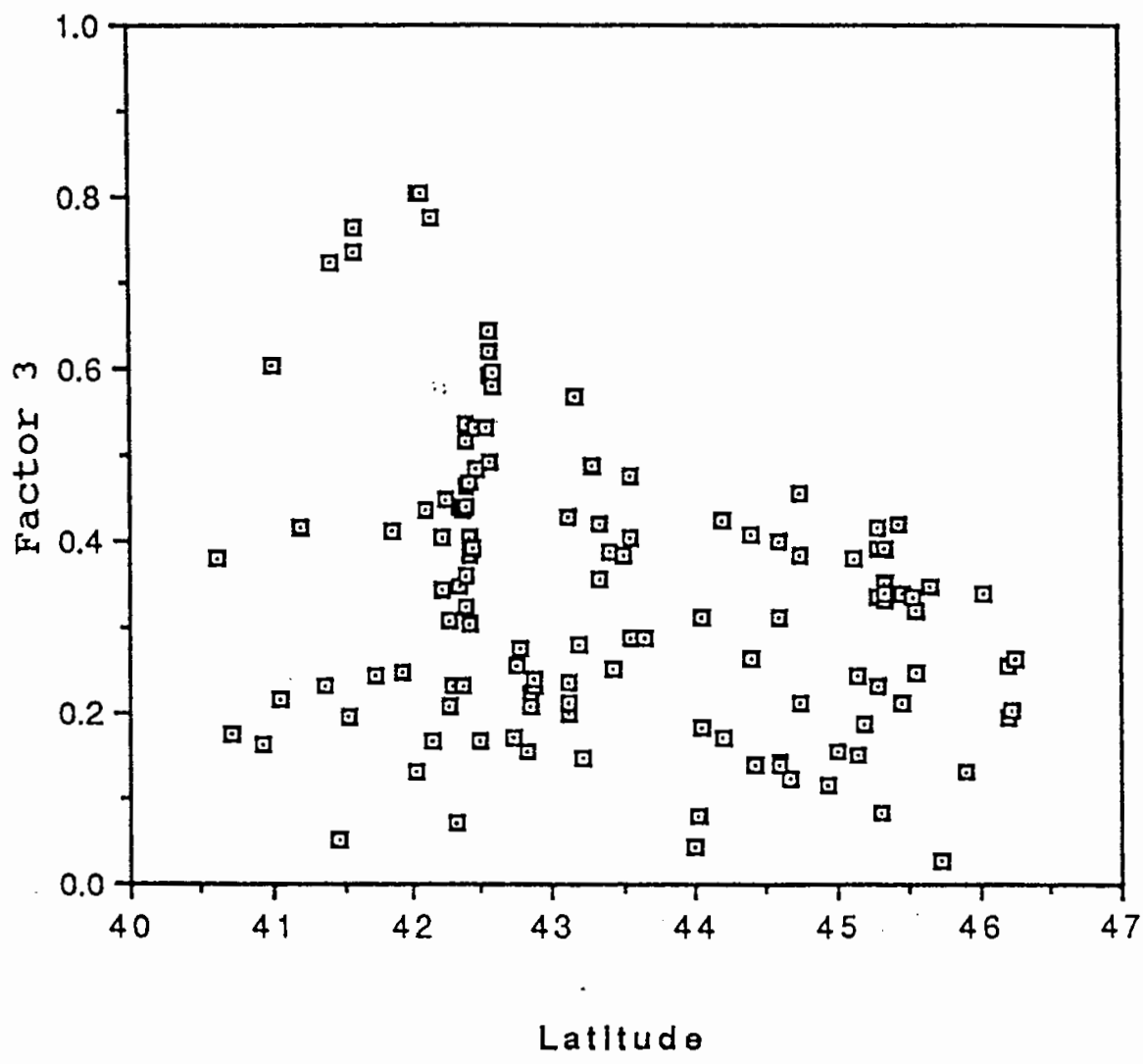

- Factor 3

Figure 42. Plot of Combined Shelf and Onshore Factor 3 Loadings as a Function of Latitude. 


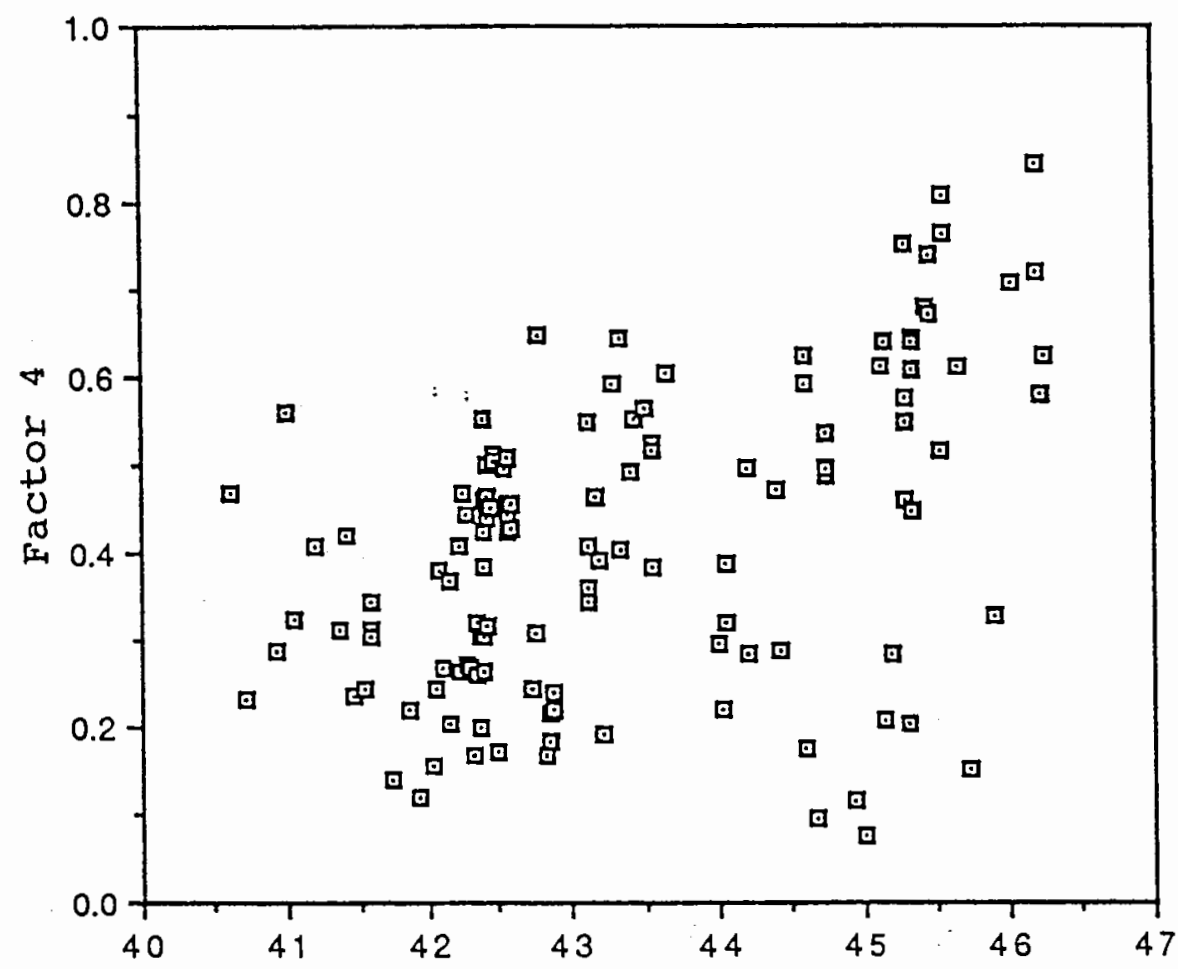

d Factor 4

\section{Latitude}

Figure 43. Plot of Combined shelf and Onshore Factor 4 Loadings as a Function of Latitude. 
less $\mathrm{Ti}$-rich oxides. The third factor is dominated by $\mathrm{Na}$, $\mathrm{Al}, \mathrm{Mg}, \mathrm{Ca}$ and SC (Figure 42) appears to represent a northern Klamath source terrain. The fourth factor is high in $\mathrm{Na}, \mathrm{La}, \mathrm{Ce}, \mathrm{Sm}$ and $\mathrm{Eu}$ (Figure 43), and displays maximum loadings between north of $45.5^{\circ}$. The maximum loadings of this factor appear to correspond to the Columbia River source.

Q-mode factor analysis of the oxide compositional data delineates four end-member sources as discussed in the earlier section. The multivariate analysis apparently breaks the two accreted terrains (Klamath Mountain and Coast Range) into two potential source areas, and indicates a fourth factor associated with the Columbia River mouth (source). This analysis addresses the along margin/shelf variability but not the across-shelf variability as discussed earlier.

CONTOUR MAPS COMPRISING DISPERSAL OF OPAQUE OXIDE-, NONOPAQUE MINERALS AND QUARTZ GRAIN ROUNDING

Contour maps were created from the factor loadings of opaque oxide composition, and from previously reported heavy non-opaque mineral dispersal and Fourier grain-shape analysis of quartz grains. These maps (see Appendix C) are used to compare dispersal patterns produced by opaque oxide, non-opaque and quartz minerals. This allows a test of three 
independent techniques widely used to constrain (1) dispersal patterns, (2) provenance of opaque oxides in the continental shelf, and (3) site specific geochemical models of exploration. Scheidegger et al. (1971) investigated the sediment sources and heavy mineral dispersal patterns of the continental shelf sands using diagnostic (non-opaque) heavy minerals. Factor one represents Klamath Mountain provenance and it is rich in glaucophane. Factor two is typical of Coast Range provenance and is characterized with the presence of clinopyroxenes. Factor three contains orthopyroxene rich sediments off the mouths of Umpqua and Columbia Rivers. The distribution of these factor loadings indicate a net northward transport of shelf sand. Factor four is dominated by garnet rich sediments and probably derived from several of the central oregon coast rivers. Swilley (1986) studied the continental shelf area located directly offshore of the northern coastal area of Oregon, $44-46^{\circ}$. Vector analysis of the shape of quartz (Fourier grain-shape) sand grains yielded four distinct types of sediments. End-member one represents grains derived from unconsolidated dune and beach sands (grains with well rounded shape). End-member two is characterized by grains, probably derived from Columbia River detritus (grains are very angular in shape). End-member three is dominated by sediments fluvially derived from the erosion of sedimentary rocks (mixed to well rounded grains). End- 
member four represents detritus fluvially derived from volcanic rocks (grains mixed to angular shape).

O'Neal (1986) examined the shape characteristics of quartz grains from the southern oregon continental shelf between 41.5 and $44.5^{\circ} \mathrm{N}$. latitude. End-member one represents fluvially transported sediments derived primarily from the Klamath Mountain terrain. End-member two is representative of the numerous marine coastal terrace deposits and the coast Range of southern oregon. End-member three represents sands derived from the extensive beach and dune deposits located along the coast.

This study on the geochemistry and dispersal of opaque oxides from the continental shelf deposits yields four end member sources. The multivariate analysis (Q-mode factor analysis) was used to delineate similar source terrains. Factor one is high in $\mathrm{Al}, \mathrm{Cr}$, $\mathrm{Co}$ and $\mathrm{Fe}$ (is dominant in the southern shelf and corresponds to the Klamath source terrain). Factor two is high in $\mathrm{Sc}, \mathrm{Ti}$ and $\mathrm{Ta}$ (and is dominant in the northern shelf and corresponds to the coast Range terrain). Factor three is high in $\mathrm{Na}, \mathrm{Al}, \mathrm{Mg}, \mathrm{Ca}$ and Sc (appears to represent a north Klamath source terrain). Factor four is high in $\mathrm{Na}, \mathrm{La}, \mathrm{Ce}, \mathrm{Sm}$ and $\mathrm{Eu}$ (indicates maximum loadings off the Columbia River source). consequently, the resulting interpretation will compare the inferred transport mechanisms for heavy nonopaque- and opaque minerals as well as their differentiated 
source rocks. These factor loadings established a dominant west-east (across-shelf) and south-north (along-shelf) dispersal pattern for the opaque- and non-opaque minerals respectively. Furthermore, the quartz rounding also implies largely across-shelf dispersal. In summary, the sole use of non-opaque heavy mineral analysis suggests much greater northward shelf transport than is indicated by the quartz and opaque mineral tracers.

RELATIONSHIPS OF THE VARIOUS HYDRODYNAMIC MODELS

Placer mineral concentrations within beaches and rivers have been studied for quite some time, but the physical processes responsible for the grain- and shear selective sorting leading to offshore concentration of opaque minerals remain poorly studied. Recent investigations by slingerland (1977, 1984), Komar and Wang (1984), and Komar (1989) have focussed on the role of selective grain entrainment in the formation of beach placers. The formation of the placer involves processes of (1) initial hydraulic settling equivalence and (2) subsequent selective entrainment based on contrasting grain densities and sizes of the different minerals (Figures 38a). In a sand deposit of mixed grains the heavy minerals are denser and finer grained than quartz and feldspar grains. A bottom current can more easily entrain and transport the 

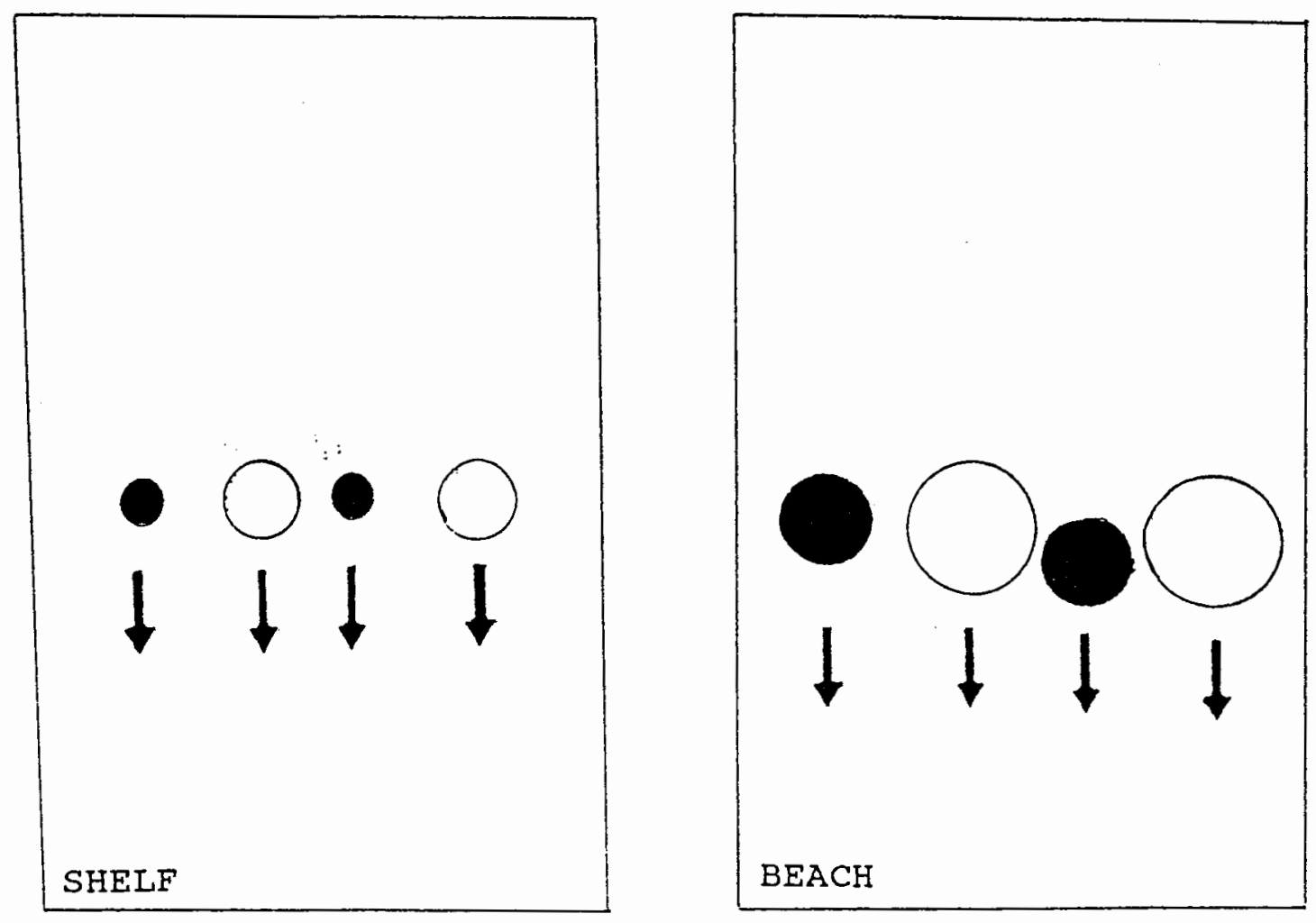

Figure 44. Hydraulic settling Equivalence Model (Komar and Wang, 1984; Komar, 1988) for the formation of heavy minerals involves process of selective entrainment and sorting according to their contrasting grain densities and sizes. The opaque- and nonopaque minerals are denoted by closed and open circles respectively. 
larger light minerals leaving behind a lag containing heavy minerals. The heavy minerals with high densities and small diameter are more resistant to shear stress, having lower exposures to the flow and greater pivoting angles.

Komar and wang (1984) have found that among the heavy minerals, hornblende is relatively easily entrained. By comparison the opaque oxides are less easily entrained due to their high density and smaller sizes. The shear sorting leading to heavy mineral deposits occur due to the initial differences in grain size settling equivalence. The sorting processes generally leave the denser opaque minerals (ilmenite, chromite and magnetite) in the placer.

Heavy minerals (10-50\% by weight) in surface sands of the continental shelf have been identified offshore of the Rogue River and shelf sands off Cape Blanco (Kulm et al., 1968a; Kulm, 1988). The heavy mineral (HM) concentrations (mineral halos up to 56 percent heavies) in the continental shelf surface sediments, suggest that anamolous concentrations of economic placers might form at a shallow subsurface depth on the shelf. Kulm (1988) suggests that offshore heavy mineral concentrations might be derived from placer mineral accumulations on the beach faces with the subsequent reworking of the beach face placers during the Holocene marine transgression. He found deep water to shallow water foraminiferal assemblages, downcore increases in heavy mineral abundances, and early Holocene $\mathrm{c}^{14}$ dates 

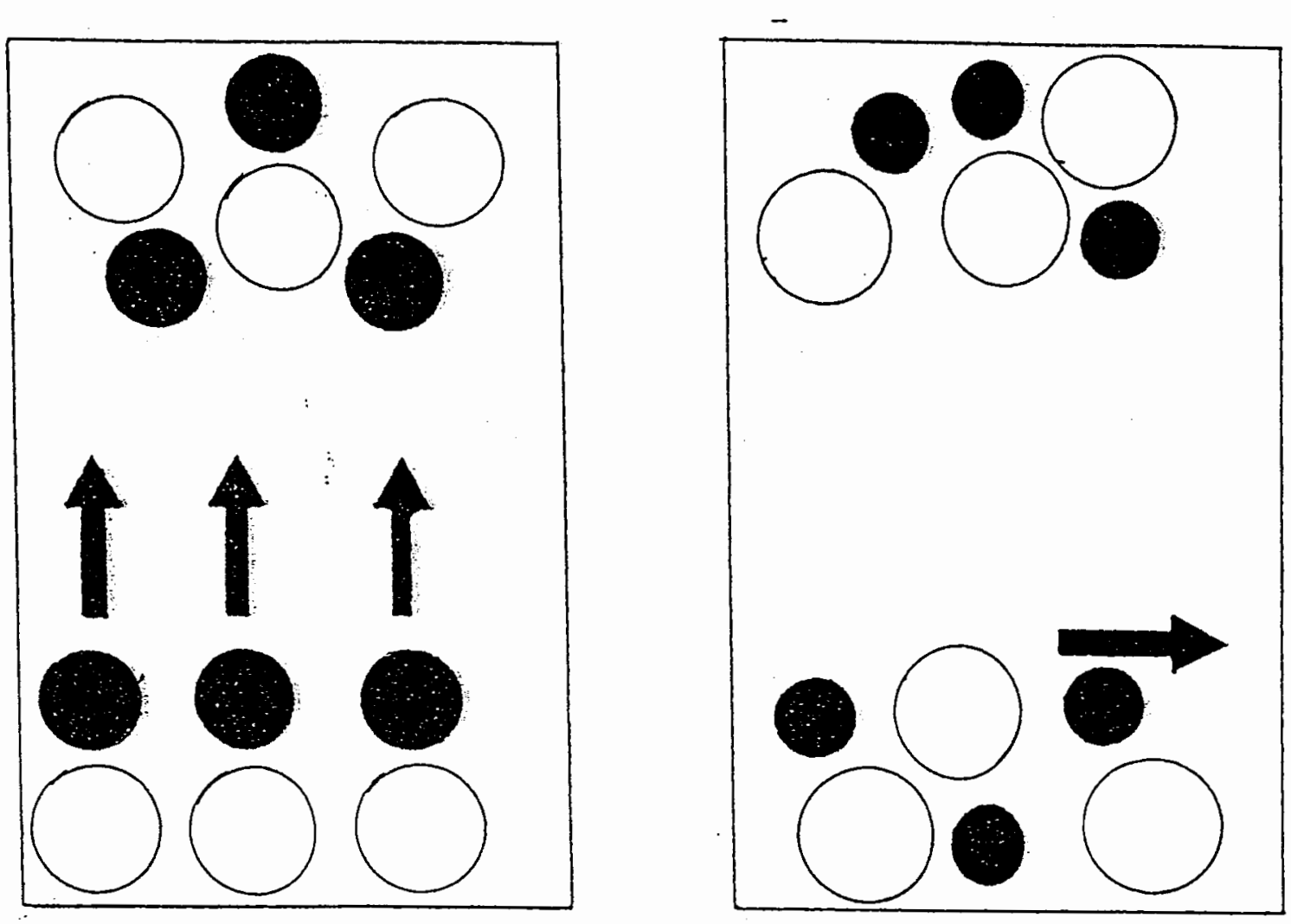

Figure 45. Kulm's hypothesis (1988) and Phillip's hypothesis (1979) relating to the formation of beach placers. Kulm (left) suggests that offshore HM concentrations can be derived from the subsequent reworking of beach placer concentrations during marine transgression, while phillip (right) suggests the potential for a shelf winnowing process coupled with local entrainment shear stress, rather than a vertical mixing of a coarser beach placer. 
from the shallow box cores ( $0.4 \mathrm{~m}$ penetration). Alternatively, the shelf HM accumulations might have formed from the winnowing of fine grained shelf deposits by offshore currents (Philiips, 1979; Figure 45). The latter hypothesis would suggest hydraulic settling equivalence but unequivalent entrainment shear stress of light and heavy placer minerals.

The results (refer to Table,5) from grain-size statistics, settling velocity equivalence and entrainment shear stress for quartz and magnetite are used, in order to constrain the origin (offshore vs onshore) for anamolous placer minerals off the continental shelf. A prevalent view for the formation of the shelf HM concentrations is heavy mineral concentrations in basal (beach) placer deposits are mixed with overlying, fine-grained shelf deposits during or after the Holocene transgression (Chambers, 1969; Kulm, 1988). In this case, the opaque minerals would not be in settling velocity equivalence with light minerals, and would be present in large-grain fractions (> 140 microns). By contrast, the results from grain-size statistics demonstrated approximate settling velocity equivalence, but widely different shear stress values. The current study results are, however, consistent with Phillip's work (1979) and suggest the potential for a shelf winnowing process, by local entrainment shear stress, rather than a vertical mixing of a coarser basal placer. The shelf winnowing 
process, possibly forced by the focussing of storm geostrophic currents around headlands could account for the association of shelf HM concentrations around prominent headlands.

The wave and storm generated currents, shelf currents and bio-geochemical mixing can affect the surficial heavy mineral distribution on the continental shelf. The lack of a three dimensional study (deep penetration vibra cores) of opaque mineral enrichments precludes one from further constraining the models for continental shelf placers.

MINERAL ECONOMIC GRADE AND SILICATE CONTAMINANTS

The INAA analysis of the opaque mineral fractions indicate the relative latitudinal variation of the chromium and titanium bearing iron oxides. A total of 20 shelf samples were analyzed for opaque oxide chemistry by electron microprobe (Mumford, 1991; personal communication). Chromite is relatively abundant in the shelf sands southern oregon and it has an average chromium oxide content of $>28 \%$ in the samples analyzed. The average ratios of chromium to iron in these samples are 1.07 (Blanco) and 1.43 (Umpqua; Table XII).

Ilmenite is abundant offshore of northern Oregon. The average titanium oxide content of ilmenite (defined as $>20 \%$ $\mathrm{Ti}$ is $26 \% \mathrm{Ti}$ from one sample. Trace element contaminants 
( $\mathrm{Ca}, \mathrm{Mg}$ and $\mathrm{Mn}$ ) in the shelf ilmenite grains totalled less than $3 \%$. The chromite grade $(\% \mathrm{Cr})$ and ilmenite grade $(\%$ Ti) was determined in order to evaluate the economic and strategic resource potential for the shelf deposits. In summary, the chromite on the southern Oregon shelf appears to be of commercial grade. While, the ilmenite would require economic upgrading in order to be used for commercial interests (KuIm and Peterson, 1989). 
TABLE XII

SUMMARY OF AVERAGE SHELF MICROPROBE ANALYSIS

SHELF Average Average $\mathrm{Cr}$ :Fe ratio $\mathrm{Ti}$ Grains $\mathrm{Cr}$

Grains

Ti $\quad \mathrm{Cr}$

Umpqua $\mathrm{S} 68 \quad 26.307 \quad 28.473 \quad 1.43 \quad 40$

$123 \mathrm{~m}$

Blanco

S17 $25.977 \quad 29.046$

1.07

46

39

$21 \mathrm{~m}$

Blanco

$\mathrm{S} 16$

26.716

24.466

1.19

22

21

$27 \mathrm{~m}$

Rogue 548

28.364

18.425

0.51

13

25

$17 \mathrm{~m}$

Rogue $551 \quad 25.084$

23.596

0.85

17

33

$70 \mathrm{~m}$

Klamath S5 27.469

25.053

0.92

8

30

$50 \mathrm{~m}$

Note: Titanium oxide values: $\mathrm{Ti}$ content $>20 \%$

Chromium oxide values: $\mathrm{Cr}$ content $>5 \%$ 
CHAPTER VIII

CONCLUSIONS

The following conclusions have been reached concerning the mineralogy, geochemistry, and provenance of opaque oxides derived from the continental shelf placer deposits. 1) Elemental analyses of the bulk opaque mineral fractions have resulted in delineation of potential offshore mineral resources representing discrete provenances on the shelf. High values of $\mathrm{Ti}$ (exceeding $20 \mathrm{wt} \%$ ) are found in the northern shelf between latitudes $42.5^{\circ}$ and $46.0^{\circ}$. By contrast, the elevated $C r$ values (4-6 wt\%) are restricted to the southern shelf between latitudes $40.5^{\circ}$ and $42.5^{\circ}$. The shelf opaque mineral geochemistry reflects an across-shelf mineral dispersal pattern, rather than a south-north (alongshelf) dispersal pattern as indicated by non-opaque heavy mineral analysis (Scheidegger et al., 1971). The contrasting distributions of chromium-rich oxides (south of $43^{\circ}$ ) and titanium-rich oxides (north of $43^{\circ}$ ) delineated different source rocks from the Klamath Mountains (south) and the Coast Range (north). 
2) Linear regressions of specific major and trace element pairs have established trace-element partitioning into the dominant opaque oxide phases. Strong correlations between the relative abundances of some trace and major element pairs (Co-Cr, Ta-Ti, Hf-Ti, SC-Ti and V-Fe) indicated that these trace elements are selectively partitioned into the dominant mineral phases based on valence and ionic radii constraints. The local and regional variations in abundance of the non-partitioned LREE ( $\mathrm{La}, \mathrm{Ce}$, and $\mathrm{Sm}$ ) discriminated the different source rocks associated with a Klamath Mountain source and a Columbia River source respectively. 3) Initial investigations of the mineral-grain size relations of the sixes River do not support the hypothesis that apparent elevated relative abundances of chromite in beach deposits results from coarse grained chromite in source rocks.

4) Grain-mineral and -size distributions from the six box core samples representing the inner-shelf near Cape Blanco (S. Oregon) established possible origins for placers on the shelf. The results demonstrate approximate settling velocity equivalence, but widely different shear stress values. These results suggest the potential for a shelf winnowing process, by local entrainment shear stress, rather than a vertical mixing of a coarser basal placer. 5) The microprobe analyses of the opaque minerals have determined accurate mineral economic grade within the 
specific oxide mineral phases ilmenite, chromite and magnetite from the shelf placers. Average titanium oxide values for the ilmenite (defined as $20 \% \mathrm{Ti}$ ) range from 25.08 to $27.47 \% \mathrm{Ti}$ for the samples derived from the inner-shelf and mid-shelf regions offshore of the Rogue River. Trace element contaminants ( $\mathrm{Ca}, \mathrm{Mg}$ and $\mathrm{Mn}$ ) in the shelf ilmenite grains totalled less than $3 \%$. The average chromium values for chromite (defined as $>5 \% \mathrm{Cr}$ ) from the shelf samples range from 18 to $29 \% \mathrm{Cr}$ based on the eight averaged chromite analyses. Silicate contaminants $\mathrm{Al}, \mathrm{Mg}$ accounted for $15 \%$ in the analyzed chromites. The average iron oxide values for magnetite from the shelf samples range from 60 to $62 \%$ (\%Fe) in magnetites. Whereas, silicate contaminants $V, M$ and $A l$ in the shelf magnetite grains generally totalled less than $2 \%$.

6) Multivariate ( $Q$-mode) analysis on the combined shelfbeach-river geochemical data have resulted in four factors accounting for over 95\% of the data variance. Factor 1 is high in $\mathrm{Al}, \mathrm{Cr}$, Co and Fe; Factor 2 is high in SC, Ti and $\mathrm{Ta}$; Factor 3 is high in $\mathrm{Na}, \mathrm{Al}, \mathrm{Mg}, \mathrm{Ca}$ and $\mathrm{Sc}$; while Factor 4 is high in Na, La, Ce, Sm and Eu. Combined shelf/onshore Factor 1 is dominant in the southern shelf and corresponds to the Klamath source terrain. Factor 2 is dominant in the northern shelf and corresponds to the Coast Range terrain. Factor 3 appears to represent a north Klamath source terrain, and Factor 4 shows maximum loadings off the 
Columbia River mouth. These factors demonstrate dominant across-shelf dispersal rather than along-shelf dispersal as previously reported. 


\section{REFERENCES}

Baldwin, E.W., 1964, Geology of oregon: University of Oregon, Eugene, Oregon, $165 \mathrm{p}$.

Beiersdorf, H., Kudrass, H.R., and von stackelberg, U., 1980, Placer deposits of ilmenite and zircon on the Zambezi shelf: Geologisches Jahrbuch, Reihe D, Heft 36, Hannover, p.5-85.

Chambers, D.M., 1969, Holocene sedimentation and potential placer deposits on the continental shelf off the Rogue River, Oregon: Corvallis, oregon, oregon stateUniversity unpublished M.S.thesis, $83 \mathrm{p}$.

Darby, D.A., 1984, Trace elements in ilmenite: A way to discriminate provenance or age in coastal sands: Geological Society of America Bulletin, v.95, p.12081218 .

Day, D.T., and Richards, R.H., 1906, Useful minerals in the black sands of the Pacific slope: U.S. Geological Survey, Mineral Resources of the United States 1905, p. 1175-1246.

Everts, C.H., 1972, Exploration for high energy marine placer sites: Part 1-Field and flume tests, North Carolina coast: Madison, Wisconsin, The University of Wisconsin Sea Grant Program Report WIS-SG-72-210, 179 p.

Gibbs, R.J., Matthews, M.D., and Link, D.A., 1971, The relationship between sphere size and settling velocity: Journal of Sedimentary Petrology, v.41, p.718.

Griggs, A.B., 1945, Chromite-bearing sands of the southern part of the coast of oregon: U.S. Geological Survey Bulletin 945-E, p.113-150.

Gross, M.G., and Nelson, J.L., 1966, Sediment movement on the continental shelf near Washington and Oregon: Science, v.151, p.1-3. 
Hevesy, G., and Levi, H., 1936, The use of neutrons in analytical chemistry: Mathematical Physics Medicine, v.14, no $5,34 \mathrm{p}$.

Horner, R.R., 1918, Notes on the black sand deposits of southern oregon and northern California: U.S. Bureau of Mines Technical Paper 196, 42 p.

Irwin, W.P., 1966, Geology of the Klamath Mountains Province: California Division of Mines and Geology Bulletin, v.190, p.19-38.

Irwin, W.P., 1981, Tectonic accretion of the Klamath Mountains, in Ernst, W.G., ed., The geotectonic development of California: Englewood Cliffs, NewJersey, Prentice-Hall, p.29-49.

Kelly, J.V., 1947, Columbia River magnetite sands, ClatsopCounty, oregon, and Pacific county, Washington, Hammond and McGowan deposits: U.S. Bureau of Mines Report of Investigations $4011,7 \mathrm{p}$.

Klovan, J.E., and Meisch, A.T., 1976, Extended CABFAC and Qmodel computer programs for Q-mode factor analysis of compositional data: Computers and Geosciences, v.1, p.161-178.

Knoll, G.F., 1979, Radiation Detection and Measurement: John wiley and Sons, New York, NY, p.313-316.

Komar, P.D., 1981, The applicability of the Gibbs equation for grain settling velocities to conditions other than quartz in water: Journal of Sedimentary Petrology, v.51, p.1125-1132.

Komar, P.D., and Wang, C., 1984, Processes of selective grain transport and formation of placers on beaches: Journal of Geology, v.92, p.637-655.

Komar, P.D., and Clemens, K.E., 1986, The relationship between a grain's settling velocity and threshold of motion under unidirectional currents: Journal of Sedimentary Petrology, v.56, p.258-266.

Komar, P.D., 1988, Physical processes of waves and currents and the formation of marine placers: Aquatic sciences, v.1, n.3, p.393-423. 
Kudrass, H.R., 1987, sedimentary models to estimate the heavy mineral potential of shelf sediments, in Marine Minerals: Advances in Research and Resource Assessment, Teleki, P.G. et al., Eds., NATO Advanced study Institutes series $C$, Mathematical and Physical Sciences.

Kulm, L.D., Heinrichs, D.F., Buerhrig, R.M., and Chambers, D.M., 1968, Evidence for possible placer accumulations on the southern oregon continental shelf: oregon Geology, v.30, p.165-184.

Kulm, L.D., Rouse, R.C., Harlett, J.C., Neudeck, R.H., Chambers, D.M., and Runge, E.J., 1975, Oregon continental shelf sedimentation: Interrelationships of facies distribution and sedimentary processes: Journal of Geology, v.83, p.145-175.

Kulm, L.D., 1988, Potential heavy mineral and metal placers on the southern oregon continental shelf: Marine Mining, v.7, p.361-395.

Kulm, L.D., and Peterson, C.D., 1989, Preliminary economic evaluation of continental shelf placer deposits off Cape Blanco, Rogue River, and Umpqua River: Oregon Department of Geology and Mineral Industries open File Report $x-x x-x$, Portland, oregon, $25 \mathrm{p}$.

Laul, J.A., 1979, Neutron activation analysis of geological materials: Atomic Energy Review, v.17, no 3, p.603695.

Lupeke, G., 1980, Opaque minerals as aids in distinguishing between source and sorting effects on beach-sand mineralogy in southwestern Oregon: Journal of Sedimentary Petrology, v.50, p. 489-496.

Mallik, T.K., 1986, Micromorphology of some placer minerals from Kerala beach, India: Marine Geology, v.71, p. $371-381$.

Mooney, W.D., and Weaver, C.S., 1989, Regional crustal structure and tectonics of the Pacific coastal states; California, Oregon, and Washington, in Pakiser, L.C., and Mooney, W.D., Geophysical framework of the continental United States: Boulder, Colarado, Geological Society of America Memoir 172, p.129-161.

Moore, G.W., and Silver, E.A., 1968, Gold distribution on the sea floor off the Klamath Mountains, California: U.S. Geological Survey Circular 605, 9 p. 
Mumford, D.F., 1988, Geology of the Elsie-lower Nehalem River area, south-central Clatsop and northern: Tillamook counties, northwestern oregon: Corvallis, oregon, Oregon state University unpublished M.S.thesis, 392 p.

O'Neal, M.A., 1986, Sources, transport, and dispersal history of southern oregon continental shelf sediments: Fourier grain-shape analysis: Wichita, Kansas, Wichita state University unpublished M.S. thesis, $107 \mathrm{p}$.

Page, B.M., 1966, Geology of the coast ranges of California: California Division of Mines and Geology Bulletin, v. 190, p.255-276.

Pardee, J.T., 1934, Beach placers of the oregon coast: U.S. Geological Survey Circular 8, 41 p.

Peck, D.L., Griggs, A.B., Schlicker, H.G., Wells, F.G., and Dole, H.M., 1964, Geology of the central and northern parts of the western Cascade Range in oregon: U.S. Geological Survey Professional Paper 449, 56 p.

Peterson, C.D., Komar, P.D., and Scheidegger, K.F., 1986, Distribution, geometry, and origin of heavy mineral placer deposits on oregon beaches: Journal of Sedimentary Petrology, v.56, no.1, p.67-77.

Peterson, C.D., Gleeson, G.W., and Wetzel, N., 1987, Stratigraphic development, mineral sources and preservation of marine placers from Pleistocene terraces in southern oregon, U.S.A: sedimentary Geology, v.53, p.203-229.

Peterson, C.D., and Binney, S.E., 1988, Compositional variations of coastal placers in the Pacific Northwest, U.S.A: Marine Mining, v.7, p.397-416.

Peterson, C.D., and Kulm, L.D., 1989, An investigation of heavy mineral placers on the oregon continental shelf: oregon Division of State Lands.

Peterson, C.D., Binney, S.E., and Kulm, L.D., (in prep), Elemental composition of economic opaque mineral fractions from river sources and coastal placers of the Pacific Northwest, U.S.A. 
Phillips, R.L., 1979, Heavy minerals and bedrock minerals on the continental shelf of Washington, oregon, and California, in outer Continental Shelf Mining Policy Phase II Task Force, Feasibility Document: outer Continental Shelf Hard Minerals Leasing, U.S. Geological Survey, Appendix 8, 56 p.

Ramp, I., 1961, Chromite in southwestern oregon: Oregon Department of Geology and Mineral Resources Bulletin, v. 52, $169 \mathrm{p}$.

Rubey, W.W., 1933, The size distribution of heavy minerals within a waterlaid sandstone: Journal of Sedimentary Petrology, v.3, p.3.

Sallenger, A.H., 1979, Inverse grading and hydraulic equivalence in grain flow deposits: Journal of Sedimentary Petrology, v.49, p.553-562.

Scheidegger, K.F., KuIm, L.D., and Runge, E.J., 1971, Sediment sources and dispersal patterns of oregon continental shelf sands: Journal of Sedimentary Petrology, v.71, p.1112-1120.

Slingerland, R.L., 1977, The effects of entrainment on the hydraulic equivalence relationships of light and heavy minerals in sands: Journal of Sedimentary Petrology, v. 47, p. $753-770$.

Smith, J.D., and Hopkins, T.S., 1972, Sediment transport on the continental shelf off of Washington and oregon in light of recent current measurements, in D.J.P. Swift, D.B. Duane, and O.H., Pilkey, eds., shelf sediment transport-Process and pattern: stroudsburg, Pennsylvania, Dowden, Hutchinson, and Ross, Inc., chapter 7, p.143-180.

Snavely, P.D., Mcleod, N.S., and Wagner, H.C., 1968, Tholeiitic and alkalic basalts of the Eocene Siletz River Volcanics, Oregon Coast Range: American Journal of Science, v.266, p.454-481.

Spigai, J.J., 1971, Marine geology of the continental margin off southern oregon: Corvaliis, oregon, Oregon state University unpublished Ph.D. thesis, $214 \mathrm{p}$.

Stapor, F.W., 1973, Heavy mineral concentratin processes and density/shape/size equilibria of marine and coastal dune sands from the Apalachicola, Florida, region: Journal of Sedimentary Petrology, v.43, p.396-407. 
Swilley, G.K., 1986, Fourier grain shape analysis of sediments from the continental shelf off the coast of northern Oregon: Wichita, Kansas, Wichita state University unpublished M.s. thesis, 109 p.

Taylor, S.R., and Mclennan, S.M., 1985, The Continental Crust: Its Composition and Evolution: Blackwell, oxford, $312 \mathrm{p}$.

Twenhofel, W.H., 1946, Mineralogical and physical composition of the sands of the oregon coast from coos Bay to the mouth of the Columbia River: Oregon Department of Geology and Mineral Industries Bulletin $30,64 \mathrm{p}$.

Venkatarathnam, K., and MCNamus, D.A., 1973, Origin and distribution of sands and gravels on the northern continenta: shelf off Washington: Journal of Sedimentary Petrology, v.43, p.799-811.

Wells, R.E., Engebretson, P.D., Snavely, Jr., and Coe, R.S., 1984, Cenozoic plate motions and the volcano-tectonic evolution of western oregon and Washington: Tectonics, v.3, p.275-294.

Whetten, J.T., Kelley, J.C., and Hanson, L.G., 1969, Characteristics of Columbia River sediment and sediment transport: Journal of Sedimentary Petrology, v.39, p.1149-1186.

White, S.M., 1967, Mineralogy and geochemistry of continental shelf sediments off Washington-oregon coast: Journal of Sedimentary Petrology, v.40, p.3854 . 


\begin{tabular}{|c|c|c|c|c|c|c|c|}
\hline & Samplo & Longitude & Latitude & $N$ & $\mathrm{Mg}$ & Al & $\mathrm{Ca}$ \\
\hline 1 & s.1 & 124.18 & 41.00 & 3175.90 & 113388.00 & 25951.00 & 72635.00 \\
\hline 2 & $S-2$ & 124.18 & 41.20 & 1411.30 & 40477.00 & 22447.00 & 36244.00 \\
\hline 3 & $5-3$ & 124.17 & 41.42 & 2320.60 & 123557.00 & 25095.00 & 44432.00 \\
\hline 4 & $S .4$ & 124.36 & 41.59 & 2190.30 & 100433.00 & 26369.00 & 57632.00 \\
\hline 5 & S.5 & 124.31 & 41.59 & 1869.30 & 92481.00 & 27098.00 & 57438.00 \\
\hline 6 & S.6 & 124.16 & 41.59 & 1697.10 & 106004.00 & 25023.00 & 50357.00 \\
\hline 7 & S-7 & 124.39 & 42.08 & 2363.80 & 144350.00 & 22775.00 & 63616.00 \\
\hline 8 & 5.8 & 124.50 & 42.29 & 613.60 & 28138.00 & 15877.00 & 8333.00 \\
\hline 9 & S-9 & 124.43 & 42.28 & 878.80 & 49376.00 & 22081.00 & 12072.00 \\
\hline 10 & S.10 & 124.41 & 42.58 & 2903.00 & 74980.00 & 24589.00 & 30002.00 \\
\hline 11 & S-11 & 124.38 & 42.56 & 3348.20 & 96056.00 & 35214.00 & 33297.00 \\
\hline 12 & S-12 & 124.55 & 42.57 & 3285.20 & 65508.00 & 26214.00 & 35145.00 \\
\hline 13 & $S .13$ & 124.48 & 42.57 & 2535.30 & 105352.00 & 26292.00 & 37205.00 \\
\hline 14 & $S-14$ & 124.71 & 42.53 & 2877.40 & 65.633 .00 & 25361.00 & 30134.00 \\
\hline 15 & $S-15$ & 124.61 & 42.87 & 486.20 & 26341.00 & 13824.00 & 8565.00 \\
\hline 16 & S-16 & 124.58 & 42.88 & 461.70. & 36641.00 & 13298.00 & 6022.00 \\
\hline 17 & S.17 & 124.57 & 42.86 & 426.20 & 28751.00 & 15816.00 & 7166.00 \\
\hline 18 & S.18 & 124.70 & 43.16 & 2737.90 & 68594.00 & 23723.00 & 36558.00 \\
\hline 19 & S.19 & 124.45 & 43.20 & 1436.90 & 32116.00 & 18437.00 & 12913.00 \\
\hline 20 & S.20 & 124.41 & 43.35 & 1763.50 & 44160.00 & 21238.00 & 17474.00 \\
\hline 21 & 5.21 & 124.51 & 43.56 & 2434.90 & 72318.00 & 23572.00 & 31361.00 \\
\hline 22 & S.22 & 124.37 & 43.56 & 2335.40 & 50671.00 & 22388.00 & 23817.00 \\
\hline 23 & 5.23 & 124.14 & 43.56 & 1245.30 & 41632.00 & 15479.00 & 11225.00 \\
\hline 24 & S.24 & 124.41 & 44.20 & 2566.90 & 66301.00 & 19840.00 & 21859.00 \\
\hline 25 & $S-25$ & 124.60 & 44.39 & 2476.70 & 50662.00 & 20775.00 & 25705.00 \\
\hline 26 & S.26 & 124.27 & 44.38 & 1519.40 & 32731.00 & 16960.00 & 19284.00 \\
\hline 27 & 5.27 & 124.17 & 44.58 & 294.30 & 26501.00 & 8847.00 & 4164.00 \\
\hline 28 & 5.28 & 124.22 & 45.11 & 3175.30 & 40340.00 & 21172.00 & 27946.00 \\
\hline 29 & 5.29 & 124.40 & 45.35 & 3760.30 & 33262.00 & 21230.00 & 27579.00 \\
\hline 30 & S.30 & 124.26 & 45.35 & 3148.20 & 33522.00 & 18613.00 & 24233.00 \\
\hline 31 & $S-31$ & 124.12 & 45.35 & 2689.50 & 46637.00 & 18362.00 & 32723.00 \\
\hline 32 & 5.32 & 123.97 & 45.35 & 2691.30 & 35547.00 & 15240.00 & 20608.00 \\
\hline 33 & 5.33 & 124.28 & 45.56 & 3586.50 & 34406.00 & 19115.00 & 28895.00 \\
\hline 34 & $S-34$ & 124.26 & 46.20 & 2697.70 & 26090.00 & 16253.00 & 19417.00 \\
\hline 35 & S-35 & 124.29 & 46.20 & 4799.00 & 47858.00 & 22526.00 & 33736.00 \\
\hline 36 & 5.37 & 124.37 & 42.10 & 1157.50 & 65874.00 & 27436.00 & 22435.00 \\
\hline 37 & $5-38$ & 124.39 & 42.15 & 2218.90 & 111129.00 & 29201.00 & 59305.00 \\
\hline 38 & 5.39 & 124.37 & 42.15 & 383.90 & 29385.00 & 21206.00 & 8054.00 \\
\hline 39 & $S .40$ & 124.41 & 42.21 & 1126.90 & 57686.00 & 26085.00 & 22739.00 \\
\hline 40 & S.41 & 124.44 & 42.35 & 872.30 & 47288.00 & 25479.00 & 16615.00 \\
\hline 41 & 5.43 & 124.46 & 42.35 & 1245.30 & 60338.00 & 25624.00 & 21328.00 \\
\hline 42 & $S-44$ & 124.46 & 42.36 & 1212.70 & 52523.00 & 26688.00 & 24344.00 \\
\hline 43 & S.45 & 124.46 & 42.39 & 1065.40 & 53446.00 & 22595.00 & 19676.00 \\
\hline 44 & 5.46 & 124.56 & 42.39 & 2267.30 & 56122.00 & 23149.00 & 21479.00 \\
\hline 45 & 5.47 & 124.56 & 42.23 & 2078.00 & 66995.00 & 2364.00 & 23102.00 \\
\hline 46 & 5.48 & 124.44 & 42.40 & 1679.00 & 74702.00 & 24297.00 & 30196.00 \\
\hline 47 & 5.49 & 124.44 & 42.40 & 1853.70 & 57783.00 & 23712.00 & 20074.00 \\
\hline 48 & S.50 & 124.58 & 42.42 & 2178.90 & 60847.00 & 22419.00 & 22654.00 \\
\hline 49 & $S-51$ & 124.54 & 42.42 & 2303.00 & 49113.00 & 18934.00 & 15983.00 \\
\hline 50 & S-52 & 124.54 & 42.25 & 2298.40 & 59304.00 & 21013.00 & 20713.00 \\
\hline 51 & S-53 & 124.65 & 42.47 & 2731.00 & 65563.00 & 22422.00 & 31206.00 \\
\hline 52 & S.54 & 124.65 & 42.47 & 2335.50 & 71424.00 & 24354.00 & 25306.00 \\
\hline 53 & 5.55 & 124.48 & 42.57 & 2087.10 & 76634.00 & 25649.00 & 33909.00 \\
\hline 54 & S.56 & 124.41 & 42.58 & 2688.80 & 83372.00 & 23726.00 & 27044.00 \\
\hline 55 & S.57 & 124.55 & 42.38 & 2713.50 & 63141.00 & 23860.00 & 26162.00 \\
\hline 56 & S.58 & 124.42 & 42.38 & 700.30 & 50318.00 & 29425.00 & 1765100 \\
\hline
\end{tabular}




\begin{tabular}{|c|c|c|c|c|c|c|c|}
\hline & & & & & & & \\
\hline & Sample & Longitude & Latítude & $\mathrm{Na}$ & Mg & Al & $\mathrm{Ca}$ \\
\hline 57 & S-59 & 124.33 & 42.41 & 1887.90 & 53786.00 & 20841.00 & 24773.00 \\
\hline 58 & S.60 & 124.66 & 42.44 & 1566.00 & 42747.00 & 22591.00 & 25205.00 \\
\hline 59 & S.61 & 124.56 & 42.76 & 759.90 & 32547.00 & 15738.00 & 9155.00 \\
\hline 60 & S.62 & 124.68 & 43.11 & 1757.10 & 62671.00 & 21527.00 & 18120.00 \\
\hline 61 & 5.63 & 124.48 & 43.11 & 1109.50 & 37277.00 & 17772.00 & 15335.00 \\
\hline 62 & S.65 & 124.43 & 43.12 & 650.80 & 29646.00 & 18938.00 & 10548.00 \\
\hline 63 & S.66 & 124.59 & 43.29 & 2899.90 & 61966.00 & 28988.00 & 29435.00 \\
\hline 64 & S.67 & 124.28 & 43.35 & 3111.10 & 53905.00 & 28020.00 & 33954.00 \\
\hline 65 & $S .68$ & 124.41 & 43.44 & 1529.30 & 40542.00 & 20386.00 & 10859.00 \\
\hline 66 & $S .69$ & 124.14 & 44.20 & 562.80 & 33246.00 & 13788.00 & 6545.00 \\
\hline 67 & $S \cdot 70$ & 124.47 & 44.59 & 3889.10 & 57916.00 & 23589.00 & 20143.00 \\
\hline 68 & $S .71$ & 124.20 & 44.59 & 1937.10 & 48613.00 & 19055.00 & 20598.00 \\
\hline 69 & $S .72$ & 124.05 & 44.59 & 435.30 & 13898.00 & 8068.00 & 4586.00 \\
\hline 70 & $S \cdot 73$ & 124.99 & 45.14 & 594,30 & 18304.00 & 7926.00 & 6129.00 \\
\hline 71 & OR-1 & 124.54 & 43.41 & 1727.20 & 41396.00 & 20086.00 & 25283.00 \\
\hline 72 & OR-2 & 124.20 & 43.50 & 2185.30 & 45065.00 & 17935.00 & 27852.00 \\
\hline 73 & OA.3 & 124.16 & 44.05 & 688.10 & 16313.00 & 12154.00 & 11696.00 \\
\hline 74 & OA-4 & $124.43^{:}$ & 44.05 & 996.50 & 42733.00 & 17619.00 & 20680.00 \\
\hline 75 & OR.5 & 124.10 & 44.72 & 1913.90 & 75260.00 & 16689.00 & 21014.00 \\
\hline 76 & OR-6 & 124.24 & 44.72 & 1169.70 & 30986.00 & 13855.00 & 15990.00 \\
\hline 77 & OR.7 & 124.38 & 44.72 & 2388.00 & 49050.00 & 19641.00 & 35808.00 \\
\hline 78 & OR-7A & 124.02 & 45.20 & 1077.10 & 20903.00 & 10231.00 & 6512.00 \\
\hline 79 & OA-8 & 124.01 & 45.29 & 2605.50 & 55727.00 & 17076.00 & 27865.00 \\
\hline 80 & OR-9 & 124.09 & 45.29 & 1369.30 & 28505.00 & 12329.00 & 14884.00 \\
\hline 81 & OR-10 & 123.99 & 45.29 & 2784.70 & 33498.00 & 16026.00 & 25352.00 \\
\hline 82 & OR.11 & 124.06 & 45.29 & 4980.20 & 45779.00 & 24258.00 & 39197.00 \\
\hline 83 & OA.12 & 124.21 & 45.47 & 3819.30 & 37804.00 & 20191.00 & 27791.00 \\
\hline 84 & OR.13 & 124.42 & 45.47 & 2350.90 & 35978.00 & 13236.00 & 14988.00 \\
\hline 85 & OR-14 & 123.99 & 45.53 & 2346.00 & 33060.00 & 14757.00 & 26380.00 \\
\hline 86 & OR-15 & 124.07 & 45.56 & 3560.10 & 49710.00 & 19195.00 & 30757.00 \\
\hline 87 & OA-16 & 124.05 & 46.02 & 3777.30 & 34303.00 & 17924.00 & 22515.00 \\
\hline
\end{tabular}




\begin{tabular}{|c|c|c|c|c|c|c|c|}
\hline & Sc & $\mathrm{Ti}$ & V & $\mathrm{C}_{t}$ & $\mathrm{Mn}$ & Fo & Co \\
\hline 1 & 46.90 & 35571.00 & 648.50 & 20894.00 & 5045.30 & 213551.00 & 113.20 \\
\hline 2 & 35.70 & 102892.00 & 1254.70 & 41534.00 & 9092.80 & 334271.00 & 134.40 \\
\hline 3 & 41.30 & 21826.00 & 635.60 & 22066.00 & 3442.00 & 210242.00 & 120.00 \\
\hline 4. & 42.50 & 15097.00 & 849.00 & 25068.00 & 2919.00 & 221349.00 & 113.90 \\
\hline 5 & 44.10 & 21194.00 & 802.10 & 34622.00 & 3099.20 & 237744.00 & 130.90 \\
\hline 6 & 39.80 & 21750.00 & 863.00 & 31780.00 & 3043.50 & 243085.00 & 127.80 \\
\hline 7 & 49.10 & 11804.00 & 520.80 & 14703.00 & 2560.40 & 192957.00 & 106.90 \\
\hline 8 & 76.20 & 189361.00 & 1357.20 & 26844.00 & 9059.20 & 360133.00 & 115.70 \\
\hline 9 & 23.70 & 45050.00 & 2056.90 & 45470.00 & 4772.50 & 432265.00 & 161.20 \\
\hline 10 & 39.20 & 40314.00 & 1271.20 & 28771.00 & 4044.70 & 303340.00 & 123.80 \\
\hline 11 & 42.10 & 45100.00 & 1466.90 & 24015.00 & 4043.50 & 307336.00 & 117.40 \\
\hline 12 & 37.80 & 34854.00 & 1229.30 & 20193.00 & 3851.00 & 293002.00 & 109.90 \\
\hline 13 & 37.60 & 29122.00 & 1180.00 & 25324.00 & 3666.10 & 309705.00 & 124.40 \\
\hline 14 & 52.60 & 61329.00 & 1236.20 & 26525.00 & 5324.20 & 315971.00 & 118.30 \\
\hline 15 & 74.90 & 203994.00 & 1264.60 & 22843.00 & 10526.10 & 331172.00 & 100.20 \\
\hline 16 & 72.50 & 190171.00 & 1346.60 & 24821.00 & 9092.50 & 357023.00 & 112.50 \\
\hline 17 & 69.30 & 178102.00 & 1396.90 & 34137.00 & 8939.50 & 378069.00 & 131.50 \\
\hline 18 & 59.50 & 83223.00 & 1281.50 & 25203.00 & 5798.00 & 301051.00 & 107.30 \\
\hline 19 & 59.40 & 138874.00 & 1297.60 & 30015.00 & 8513.30 & 363146.00 & 125.00 \\
\hline 20 & 56.90 & 117312.00 & 1408.80 & 31631.00 & 6937.30 & 375584.00 & 126.90 \\
\hline 21 & 56.50 & 92738.00 & 1193.60 & 30310.00 & 6422.40 & 331380.00 & 125.90 \\
\hline 22 & 57.60 & 104445.00 & 1284.50 & 26655.00 & 7344.30 & 314829.00 & 109.00 \\
\hline 23 & 76.10 & 176993.00 & 1045.50 & 11178.00 & 10629.30 & 299356.00 & 79.20 \\
\hline 24 & 70.10 & 126382.00 & 1106.50 & 11109.00 & 9049.10 & 270644.00 & 87.30 \\
\hline 25 & 64.10 & 115570.00 & 1324.50 & 19191.00 & 7316.20 & 353973.00 & 107.40 \\
\hline 26 & 69.50 & 149018.00 & 1286.50 & 10976.00 & 10916.90 & 328099.00 & 78.40 \\
\hline 27. & 75.20 & 226027.00 & 1427.80 & 4143.00 & 10495.70 & 390776.00 & 66.50 \\
\hline 28 & 58.50 & 105783.00 & 1458.50 & 14355.00 & 6319.10 & 347389.00 & 97.00 \\
\hline 29 & 57.50 & 107425.00 & 1208.40 & 8615.00 & 6143.20 & 298428.00 & 80.70 \\
\hline 30 & 58.70 & 126180.00 & 1373.80 & 7819.00 & 5840.30 & 329891.00 & 84.20 \\
\hline 31 & 64.40 & 137372.00 & 1336.40 & 10657.00 & 7135.90 & 316342.00 & 85.50 \\
\hline 32 & 62.60 & 173823.00 & 1207.70 & 1823.00 & 7293.50 & 301686.00 & 72.90 \\
\hline 33 & 43.00 & 60631.00 & 1276.50 & 1548.00 & 4667.40 & 351907.00 & 59.80 \\
\hline 34 & 45.90 & 117620.00 & 1564.60 & 6654.00 & 5764.70 & 379509.00 & 75.30 \\
\hline 35 & 57.20 & 77912.00 & 1419.70 & 985.00 & 4323.70 & 274720.00 & 74.90 \\
\hline 36 & 31.90 & 52578.00 & 1804.50 & 51720.00 & 4304.00 & 402908.00 & 176.20 \\
\hline 37 & 58.50 & 16420.00 & 578.90 & 19857.00 & 3322.10 & 201994.00 & 104.10 \\
\hline 38 & 22.70 & 49270.00 & 2170.30 & 52594.00 & 4961.60 & 510830.00 & 193.20 \\
\hline 39 & 31.50 & 36418.00 & 1515.00 & 46838.00 & 4665.80 & 388495.00 & 164.80 \\
\hline 40 & 26.70 & 44180.00 & 1756.30 & 50582.00 & 4695.30 & 411683.00 & 167.40 \\
\hline 41 & 28.70 & 32791.00 & 1570.70 & 42776.00 & 4180.30 & 378230.00 & 156.40 \\
\hline 42 & 29.90 & $38400: 00$ & 1491.40 & 46195.00 & 4577.50 & 375226.00 & 161.20 \\
\hline 43 & 25.70 & 34464.00 & 1795.00 & 43417.00 & 4447.30 & 446895.00 & 171.90 \\
\hline 44 & 35.10 & 36561.00 & 1580.20 & 29002.00 & 4117.70 & 384400.00 & 129.90 \\
\hline 45 & 35.80 & 40001.00 & 1654.00 & 32224.00 & 4269.80 & 413127.00 & 138.10 \\
\hline 46 & 30.70 & 36151.00 & 1386.60 & 28319.00 & 3728.10 & 354986.00 & 140.30 \\
\hline 47 & 32.80 & 38111.00 & 1335.30 & 29490.00 & 4174.70 & 365107.00 & 143.70 \\
\hline 48 & 33.20 . & 32758.00 & 1683.80 & 27154.00 & 3883.80 & 395443.00 & 131.40 \\
\hline 49 & 35.20 & 39439.00 & 1518.20 & 20315.00 & 3962.00 & 406612.00 & 131.00 \\
\hline 50 & 34.30 & 44907.00 & 1587.20 & 21494.00 & 4085.70 & 394322.00 & 129.70 \\
\hline 51 & 42.30 & 40772.00 & 1240.00 & 27960.00 & 4526.30 & 338789.00 & 130.40 \\
\hline 52 & 37.10 & 48314.00 & 1433.40 & 29723.00 & 4799.40 & 355625.00 & 130.40 \\
\hline 53 & 3.80 & 24688.00 & 1218.00 & 26379.00 & 3750.10 & 343583.00 & 138.70 \\
\hline 54 & 35.60 & 34695.00 & 1236.90 & 25843.00 & 4266.90 & 294078.00 & 127.90 \\
\hline 55 & 40.90 & 31642.00 & 1125.60 & 20354.00 & 4212.00 & 314103.00 & 125.30 \\
\hline 56 & 40.60 & 80261.00 & 1082.20 & 72440.00 & 9174.40 & 345656.00 & 233.50 \\
\hline
\end{tabular}


Sc

$\begin{array}{llc}57 & 52.40 & 91791.00 \\ 58 & 56.00 & 86100.00 \\ 59 & 76.20 & 184369.00 \\ 60 & 56.70 & 101982.00 \\ 61 & 71.10 & 151093.00 \\ 62 & 65.40 & 154744.00 \\ 63 & 38.20 & 46283.00 \\ 64 & 51.30 & 79872.00 \\ 65 & 60.90 & 137058.00 \\ 66 & 64.10 & 196223.00 \\ 67 & 47.30 & 91935.00 \\ 68 & 65.40 & 127812.00 \\ 69 & 71.50 & 233899.00 \\ 70 & 70.40 & 242831.00 \\ 71 & 51.00 & 104127.00 \\ 72 & 64.20 & 130453.00 \\ 73 & 69.60 & 199461.00 \\ 74 & 62.30 & 164397.01 \\ 75 & 64.10 & 140045.00 \\ 76 & 67.50 & 172262.00 \\ 77 & 63.00 & 123398.00 \\ 78 & 61.00 & 209897.00 \\ 79 & 56.10 & 147004.00 \\ 80 & 64.30 & 180858.00 \\ 81 & 52.30 & 144338.00 \\ 82 & 53.80 & 96431.00 \\ 83 & 51.40 & 100463.00 \\ 84 & 64.30 & 169894.00 \\ 85 & 57.60 & 165683.00 \\ 86 & 48.90 & 92866.00 \\ 87 & 49.60 & 103474.00\end{array}$

V

1319.10
1183.10
1238.80
1231.20
1081.70
1170.10
1443.10
1119.30
1237.80
1413.60
1405.00
1128.80
1196.10
1142.50
1295.50
1134.50
1245.00
1234.60
918.50
1182.50
1075.80
1130.20
1052.60
1120.90
1175.50
1119.90
1414.40
1398.30
1411.70
1281.40
1727.80

Cr

25093.00

31277.00

24847.00

27852.00

19653.00

27277.00

25865.00

26010.00

2258.00

5464.00

11058.00

14238.00

3337.00

2320.00

26975.00

5693.00

6772.00

23532.00

3830.00

7409.00

11777.00

2026.00

1413.00

7583.00

2864.00

3871.00

6119.00

3730.00

3269.00

2406.00

3306.00
Mn

Fo

6200.80

6946.20

9573.20

6244.60

10605.30

11713.50

4615.60

8065.90

8070.20

12426.30

5752.30

8691.50

9230.10

8178.30

6795.10

7896.30

11573.10

8399.70

10129.20

9494.30

6771.30

7500.60

8028.90

8250.50

5829.40

4755.00

5021.20

6290.70

6554.40

5250.20

5099.60
363490.00

326471.00

349149.00

334839.00

323751.00

347140.00

310960.00

274905.00

335435.00

372356.00

354875.00

307240.00

367176.00

361059.00

321497.00

276904.00

338184,00

319038.00

269054.00

312917.00

282749.00

328662.00

288909.00

308851.00

297845.00

243768.00

300527.00

325282.00

307314.00

294314.00

309595.00 co

125.60

126.10

115.80

120.90

103.80

116.60

114.90

1.15 .40

105.60

80.20

108.30

91.50

64.20

61.80

116.50

74.60

76.30

103.90

70.10

73.20

88.20

68.50

73.50

78.10

78.80

72.70

82.50

80.50

78.60

74.90

81.20 


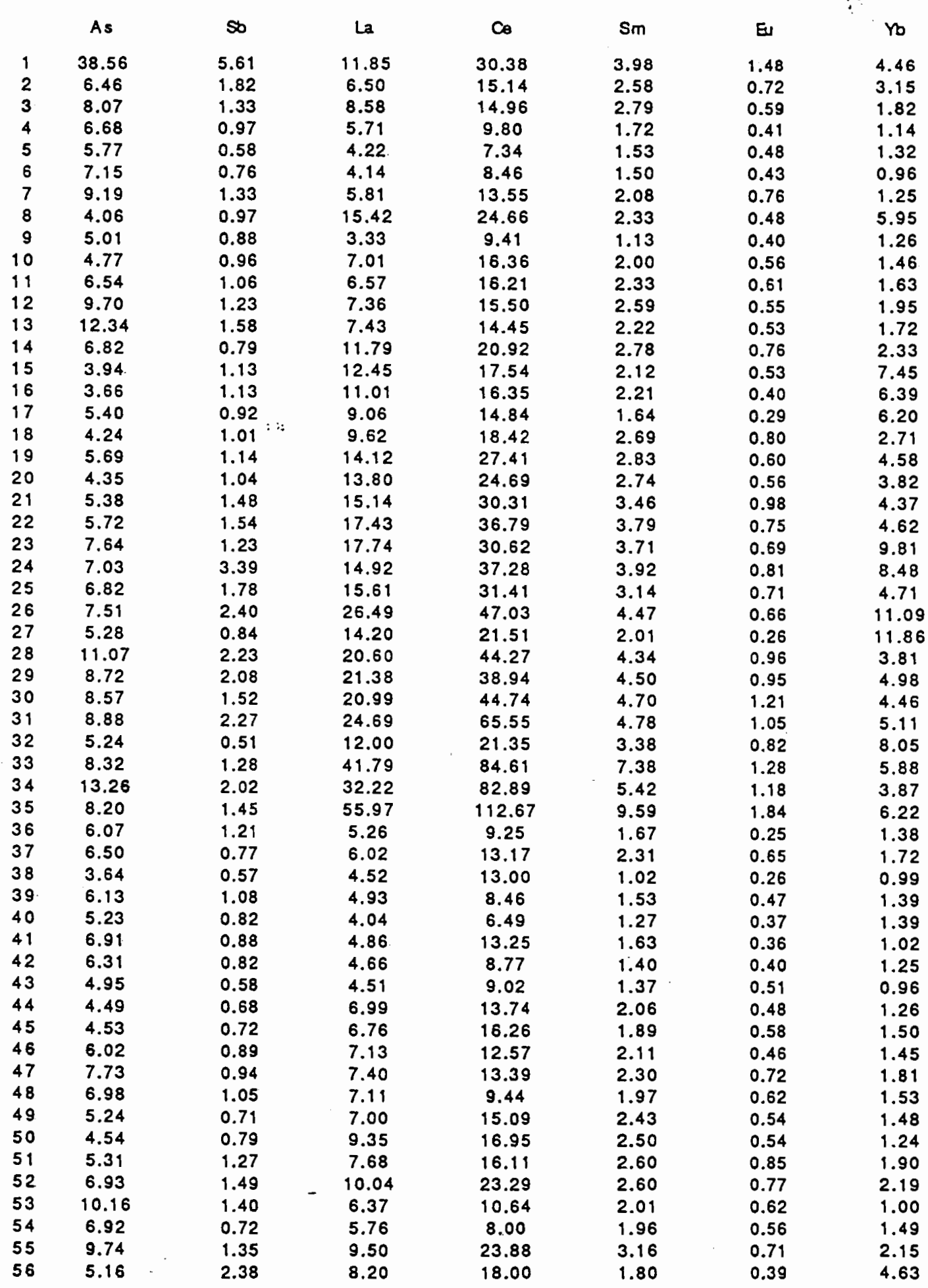




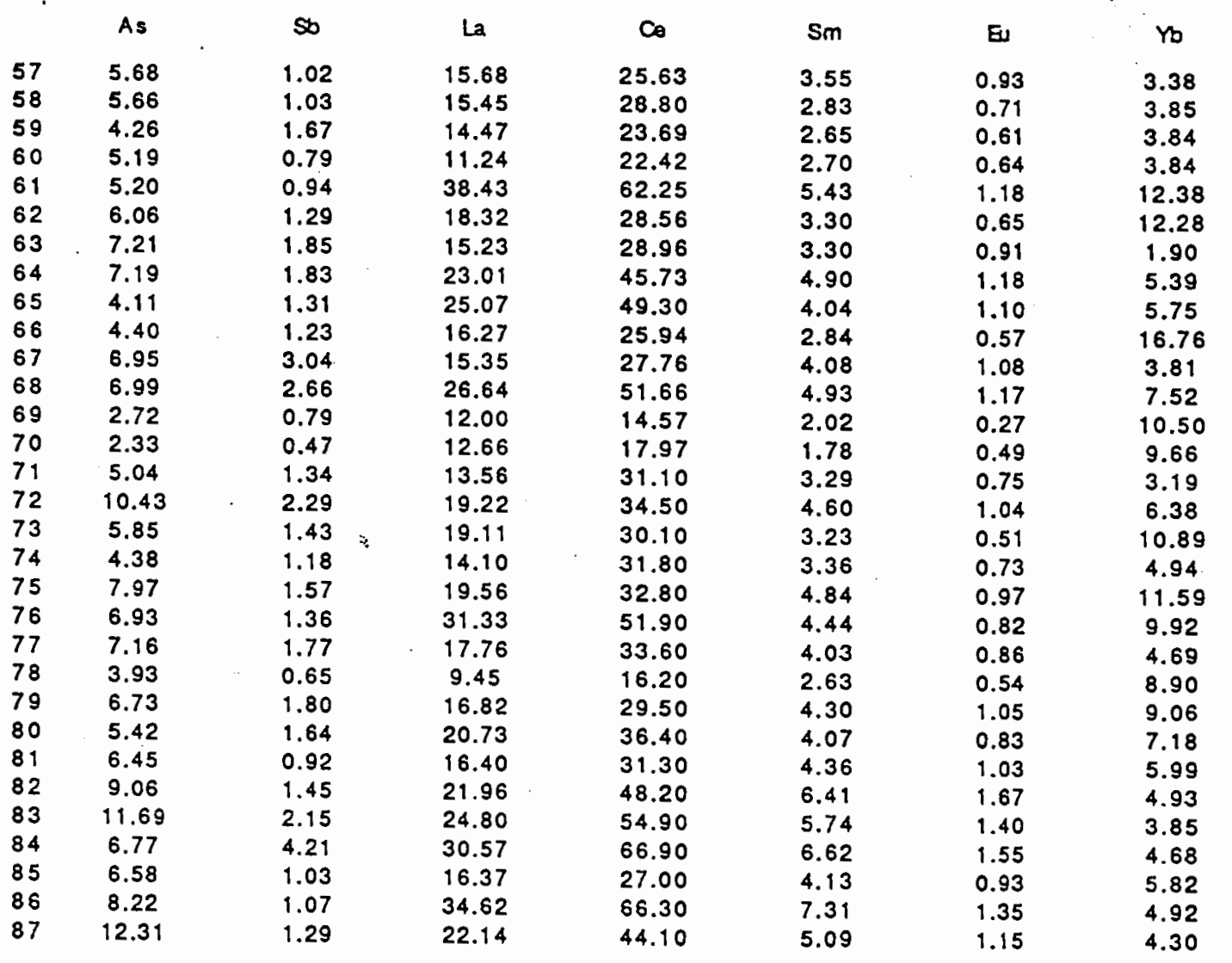


LI Ht Ta

$\begin{array}{lcc}0.43 & 2.01 & 1.52 \\ 0.36 & 4.37 & 4.45 \\ 0.24 & 1.30 & 0.77 \\ 0.17 & 0.83 & 0.31 \\ 0.16 & 1.20 & 0.92 \\ 0.12 & 1.70 & 0.51 \\ 0.11 & 1.43 & 1.10 \\ 1.05 & 13.85 & 16.11 \\ 0.19 & 3.06 & 1.85 \\ 0.21 & 2.65 & 2.34 \\ 0.27 & 2.24 & 1.48 \\ 0.17 & 2.12 & 1.06 \\ 0.14 & 2.51 & 0.83 \\ 0.29 & 4.48 & 4.58 \\ 1.17 & 12.23 & 19.06 \\ 0.85 & 13.33 & 17.22 \\ 0.90 & 15.48 & 15.63 \\ 0.45 & 4.76 & 5.60 \\ 0.91 & 9.38 & 13.24 \\ 0.49 & 8.10 & 10.45 \\ 0.50 & 6.04 & 8.51 \\ 0.65 & 7.42 & 8.90 \\ 1.34 & 12.50 & 16.34 \\ 1.40 & 10.02 & 12.68 \\ 0.77 & 11.19 & 12.51 \\ 1.88 & 14.26 & 15.98 \\ 2.09 & 25.14 & 22.24 \\ 0.47 & 9.77 & 10.30 \\ 1.10 & 8.84 & 9.79 \\ 0.78 & 10.78 & 12.09 \\ 0.80 & 12.90 & 13.08 \\ 1.20 & 14.64 & 15.23 \\ 0.85 & 8.99 & 5.55 \\ 0.59 & 10.93 & 11.27 \\ 0.84 & 10.87 & 7.46 \\ 0.18 & 1.79 & 1.16 \\ 0.23 & 1.19 & 0.72 \\ 0.37 & 3.02 & 1.46 \\ 0.15 & 2.40 & 1.32 \\ 0.17 & 2.74 & 1.54 \\ 0.17 & 1.67 & 0.91 \\ 0.12 & 1.84 & 1.55 \\ 0.16 & 2.37 & 1.13 \\ 0.21 & 2.17 & 1.25 \\ 0.21 & 2.98 & 1.38 \\ 0.21 & 2.46 & 1.22 \\ 0.17 & 1.98 & 1.48 \\ 0.17 & 2.26 & 0.85 \\ 0.14 & 3.09 & 0.61 \\ 0.11 & 2.73 & 0.59 \\ 0.29 & 1.75 & 1.75 \\ 0.24 & 2.60 & 2.08 \\ 0.16 & 1.58 & 0.45 \\ 0.18 & 1.77 & 1.88 \\ 0.14 & 2.44 & 1.14 \\ 0.70 & 4.39 & 5.92\end{array}$




$\begin{array}{lccc} & \text { L } & \text { H1 } & \text { Ta } \\ 57 & 0.85 & 10.12 & 9.27 \\ 58 & 0.70 & 8.84 & 7.80 \\ 59 & 0.95 & 12.97 & 15.64 \\ 60 & 0.54 & 8.47 & 7.70 \\ 61 & 1.87 & 11.44 & 13.56 \\ 62 & 1.80 & 16.25 & 15.11 \\ 63 & 0.30 & 2.49 & 2.12 \\ 64 & 0.81 & 6.40 & 6.77 \\ 65 & 0.80 & 11.42 & 12.47 \\ 66 & 2.43 & 18.66 & 19.10 \\ 67 & 0.43 & 9.61 & 6.56 \\ 68 & 1.13 & 9.60 & 12.35 \\ 69 & 1.95 & 20.18 & 22.22 \\ 70 & 1.69 & 20.06 & 21.88 \\ 71 & 0.54 & 6.46 & 8.31 \\ 72 & 1.13 & 11.01 & 11.76 \\ 73 & 2.15 & 14.58 & 20.37 \\ 74 & 0.88 & 12.37 & 14.45 \\ 75 & 1.97 & 10.99 & 14.92 \\ 76 & 1.46 & 14.80 & 16.81 \\ 77 & 0.81 & 8.61 & 11.21 \\ 78 & 1.46 & 17.34 & 18.28 \\ 79 & 1.49 & 12.18 & 11.95 \\ 80 & 1.14 & 14.07 & 17.66 \\ 81 & 0.98 & 13.34 & 12.92 \\ 82 & 0.71 & 9.51 & 7.62 \\ 83 & 0.53 & 9.29 & 8.72 \\ 84 & 0.78 & 11.75 & 15.10 \\ 85 & 1.03 & 12.65 & 13.97 \\ 86 & 0.68 & 9.53 & 8.99 \\ 87 & 0.75 & 8.59 & 7.52\end{array}$




\section{APPENDIX B}

\section{DETAILED FACTOR LOADINGS}




\begin{tabular}{|c|c|c|c|c|c|c|c|}
\hline & Sample & Latitude & Longitude & Factor 1 & Factor 2 & Factor 3 & Facior 4 \\
\hline 1 & S-1 & 46.20 & 124.13 & 0.15 & 0.17 & 0.10 & 0.59 \\
\hline 2 & $S .15$ & 46.14 & 124.23 & 0.31 & 0.15 & 0.09 & 0.45 \\
\hline 3 & $S-19$ & 46.11 & 124.62 & 0.11 & 0.19 & 0.32 & 0.38 \\
\hline 4 & 5.23 & 46.11 & 124.34 & 0.29 & 0.11 & 0.40 & 0.21 \\
\hline 5 & 5.39 & 46.05 & 124.38 & 0.03 & 0.31 & 0.40 & 0.27 \\
\hline 6 & 5.41 & 46.05 & 124.23 & 0.14 & 0.54 & 0.21 & 0.11 \\
\hline 7 & 5.43 & 46.05 & 124.08 & 0.08 & 0.20 & 0.37 & 0.34 \\
\hline 8 & 5.44 & 46.02 & 123.59 & 0.15 & 0.17 & 0.54 & 0.14 \\
\hline 9 & $S-63$ & 45.59 & 124.29 & 0.16 & 0.39 & 0.26 & 0.19 \\
\hline 10 & S.65 & 45.59 & 124.14 & 0.12 & 0.23 & 0.20 & 0.45 \\
\hline 11 & S-67 & 45.59 & 124.00 & 0.27 & 0.14 & 0.30 & 0.29 \\
\hline 12 & 5.87 & 45.53 & 124.28 & 0.18 & 0.22 & 0.30 & 0.30 \\
\hline .13 & 5.89 & 45.53 & 124.13 & 0.00 & 0.13 & 0.42 & 0.45 \\
\hline 14 & 5.91 & 45.53 & 123.99 & 0.29 & 0.16 & 0.46 & 0.09 \\
\hline 15 & S.95 & 45.50 & 124.18 & 0.12 & 0.24 & 0.30 & 0.33 \\
\hline 16 & 5.110 & 45.47 & 124.28 & 0.01 & 0.21 & 0.45 & 0.32 \\
\hline 17 & $S .112$ & 45.47 & 124.14 & 0.17 & 0.11 & 0.41 & 0.30 \\
\hline 18 & $S \cdot 114$ & $45.47^{\prime}$ & 123.99 & 0.21 & 0.14 & 0.47 & 0.18 \\
\hline 19 & $S-135$ & 45.41 & 124.15 & 0.18 & 0.31 & 0.06 & 0.45 \\
\hline 20 & $5-137$ & 45.41 & 124.01 & 0.35 & 0.12 & 0.33 & 0.21 \\
\hline 21 & $S-153$ & 45.35 & 124.26 & 0.28 & 0.15 & 0.43 & 0.14 \\
\hline 22 & $S .155$ & 45.35 & 124.12 & 0.19 & 0.11 & 0.36 & 0.33 \\
\hline 23 & S.157 & 45.35 & 124.97 & 0.16 & 0.01 & 0.29 & 0.53 \\
\hline 24 & S.169 & 45,29 & 124.37 & 0.43 & 0.03 & 0.47 & 0.07 \\
\hline 25 & $S \cdot 171$ & 45.29 & 124.23 & 0.28 & 0.12 & 0.26 & 0.34 \\
\hline 26 & 5.173 & 45.29 & 124.09 & 0.45 & 0.14 & 0.42 & 0.00 \\
\hline 27 & S-175 & 45.29 & 123.99 & 0.35 & 0.11 & 0.37 & 0.18 \\
\hline 28. & $S-184$ & 45.23 & 124.34 & 0.42 & 0.03 & 0.32 & 0.23 \\
\hline 29 & $S-187$ & 45.23 & 124.12 & 0.24 & 0.09 & 0.30 & 0.36 \\
\hline 30 & $S-189$ & 45.23 & 123.99 & 0.34 & 0.00 & 0.17 & 0.54 \\
\hline 31 & S.197 & 45.28 & 124.30 & 0.72 & 0.00 & 0.16 & 0.16 \\
\hline 32 & S.200 & 45.17 & 124.09 & 0.32 & 0.00 & 0.22 & 0.47 \\
\hline 33 & 5.202 & 45.17 & 123.59 & 0.41 & 0.00 & 0.42 & 0.17 \\
\hline 34 & $S .216$ & 45.11 & 124.08 & 0.35 & 0.08 & 0.46 & 0.11 \\
\hline 35 & $S-218$ & 45.11 & 123.99 & 0.40 & 0.02 & 0.13 & 0.45 \\
\hline 36 & 5.234 & 45.05 & 124.16 & 0.44 & 0.10 & 0.24 & 0.21 \\
\hline 37 & S.236 & 45.05 & 124.02 & 0.24 & 0.10 & 0.41 & 0.24 \\
\hline 38 & 5.249 & 44.59 & 124.20 & 0.19 & 0.23 & 0.14 & 0.44 \\
\hline 39 & $S .251$ & 44.59 & 124.05 & 0.24 & 0.04 & 0.53 & 0.18 \\
\hline 40 & 5.270 & 44.88 & 124.24 & 0.22 & 0.26 & 0.37 & 0.15 \\
\hline 41 & S.272 & 44.88 & 124.60 & 0.37 & 0.10 & 0.26 & 0.26 \\
\hline 42 & S.290 & 44.78 & 124.31 & 0.19 & $0: 26$ & 0.20 & 0.35 \\
\hline 43 & $S .291$ & 44.78 & 124.24 & 0.24 & 0.15 & 0.27 & 0.34 \\
\hline 44 & 5.08 .4 & 44.39 & 124.36 & 0.24 & 0.16 & 0.46 & 0.15 \\
\hline 45 & 5.330 & 44.58 & 124.31 & 0.33 & 0.03 & 0.20 & 0.44 \\
\hline 46 & S.332 & 44.58 & 124.17 & 0.45 & 0.11 & 0.33 & 0.11 \\
\hline 47 & $5-348$ & 44.48 & 124.45 & 0.40 & 0.11 & 0.30 & 0.19 \\
\hline 48 & $S-351$ & 44.47 & 124.23 & 0.38 & 0.26 & 0.12 & 0.24 \\
\hline 49 & S.353 & 44.48 & 124.11 & 0.37 & 0.00 & 0.22 & 0.41 \\
\hline 50 & $S .357$ & 44.43 & 124.31 & 0.22 & 0.00 & 0.35 & 0.43 \\
\hline 51 & $5-374$ & 44.20 & 124.14 & 0.29 & 0.07 & 0.37 & 0.27 \\
\hline 52 & $5-376$ & 44.33 & -124.26 & 0.35 & 0.09 & 0.34 & 0.22 \\
\hline 53 & 5.378 & 44.20 & 124.41 & 0.33 & 0.13 & 0.31 & 0.23 \\
\hline 54 & S-392 & 44.17 & 124.35 & 0.19 & 0.04 & 0.41 & 0.36 \\
\hline 55 & S.395 & 44.17 & 124.14 & 0.31 & 0.15 & 0.35 & 0.18 \\
\hline 56 & Umpqua $R$ & 43.67 & 124.02 & 0.00 & 0.43 & 0.26 & 0.31 \\
\hline
\end{tabular}




$\begin{array}{lcrrcrrr} & \text { Sample } & \text { Latitude } & \text { Longitude } & \text { Factor 1 } & \text { Factor 2 } & \text { Factor 3 } & \text { Factor 4 } \\ 57 & \text { Klamath R. } & 41.54 & 124.04 & 0.07 & 0.67 & 0.15 & 0.11 \\ 58 & \text { Rogue R. } & 42.42 & 124.20 & 0.08 & 0.48 & 0.20 & 0.24 \\ 59 & \text { Columbia R. } & 46.25 & 123.58 & 0.05 & 0.33 & 0.25 & 0.37 \\ 60 & \text { Smith R. } & 41.93 & 124.10 & 0.10 & 0.36 & 0.16 & 0.37 \\ 61 & \text { Alsea R. } & 44.42 & 123.59 & 0.04 & 0.37 & 0.08 & 0.51 \\ 62 & \text { Coquille R. } & 43.12 & 124.22 & 0.00 & 0.35 & 0.31 & 0.36 \\ 63 & \text { Agate Beach } & 44.67 & 124.04 & 0.38 & 0.02 & 0.28 & 0.32\end{array}$




\begin{tabular}{|c|c|c|c|c|c|c|}
\hline & Sample & Latitude & Longitude & Factor 1 & Factor 2 & Factor 3 \\
\hline 1 & 0.1 & 44.19 & 124.19 & 0.05 & 0.31 & 0.64 \\
\hline 2 & $0-2$ & 44.19 & 124.46 & 0.20 & 0.42 & 0.38 \\
\hline 3 & 0.3 & 44.13 & 124.93 & 0.08 & 0.34 & 0.58 \\
\hline 4 & 0.4 & 44.08 & 124.64 & 0.08 & 0.52 & 0.41 \\
\hline 5 & 0.5 & 44.08 & $124.43^{\circ}$ & 0.07 & 0.30 & 0.63 \\
\hline 6 & 0.6 & 44.08 & 124.30 & 0.08 & 0.43 & 0.49 \\
\hline 7 & 0.7 & 44.08 & 124.16 & 0.03 & 0.33 & 0.64 \\
\hline 8 & 0.8 & 43.98 & 124.24 & 0.00 & 0.25 & 0.75 \\
\hline 9 & -0.9 & 43.98 & 124.38 & 0.24 & 0.44 & 0.32 \\
\hline 10 & 0.10 & 43.98 & 124.51 & .0 .01 & 0.62 & 0.39 \\
\hline 11 & 0.11 & 43.93 & 124.86 & 0.18 & 0.47 & 0.36 \\
\hline 12 & 0.12 & 43.84 & 124.52 & 0.13 & 0.13 & 0.74 \\
\hline 13 & 0.13 & 43.82 & 124.45 & 0.13 & 0.45 & 0.42 \\
\hline 14 & 0.14 & 43.81 & 124.30 & 0.06 & 0.62 & 0.32 \\
\hline 15 & 0.15 & 43.82 & 124.23 & 0.05 & 0.29 & 0.66 \\
\hline 16 & 0.16 & 43.82 & 124.20 & 0.10 & 0.41 & 0.49 \\
\hline 17 & 0.17 & 43.68 & 124.27 & 0.18 & 0.56 & 0.27 \\
\hline 18 & 0.18 & 43.68 & 124.41 & 0.18 & 0.64 & 0.18 \\
\hline 19 & 0.19 & 43.68 & 124.54 & 0.54 & 0.36 & 0.10 \\
\hline 20 & 0.20 & 43.58 & 124.48 & 0.06 & 0.38 & 0.56 \\
\hline 21 & 0.21 & 43.58 & 124.41 & 0.48 & 0.30 & 0.22 \\
\hline 22 & 0.22 & 43.58 & 124.25 & 0.17 & 0.20 & 0.63 \\
\hline 23 & 0.23 & 43.48 & 124.31 & 0.32 & 0.25 & 0.43 \\
\hline 24 & 0.24 & 43.48 & 124.45 & 0.31 & 0.49 & 0.20 \\
\hline 25 & 0.25 & 43.38 & 124.57 & 0.21 & 0.62 & 0.17 \\
\hline 26 & 0.26 & 43.38 & 124.43 & 0.33 & 0.54 & 0.13 \\
\hline 27 & 0.27 & 43.27 & 124.41 & 0.20 & 0.63 & 0.17 \\
\hline 28 & 0.28 & 43.27 & 124.43 & 0.33 & 0.54 & 0.13 \\
\hline 29 & 0.29 & 43.23 & 124.46 & 0.20 & 0.63 & 0.17 \\
\hline 30 & 0.30 & 43.23 & 124.42 & -0.03 & 0.69 & 0.34 \\
\hline 31 & 0.31 & 43.13 & 124.48 & 0.19 & 0.30 & 0.51 \\
\hline 32 & 0.32 & 43.03 & 124.74 & 0.08 & 0.54 & 0.37 \\
\hline 33 & 0.33 & 43.03 & 124.56 & 0.10 & 0.46 & 0.45 \\
\hline 34 & 0.34 & 43.03 & 124.47 & 0.21 & 0.40 & 0.39 \\
\hline 35 & 0.35 & 42.93 & 124.51 & 0.08 & 0.63 & 0.29 \\
\hline 36 & 0.36 & 42.93 & 124.60 & 0.13 & 0.35 & 0.52 \\
\hline 37 & 0.37 & 42.83 & 124.71 & 0.27 & 0.33 & 0.41 \\
\hline 38 & 0.38 & 42.83 & 124.62 & 0.46 & 0.17 & 0.36 \\
\hline 39 & 0.39 & 42.73 & 124.50 & 0.26 & 0.35 & 0.39 \\
\hline 40 & 0.40 & 42.73 & 124.66 & 0.29 & 0.48 & 0.23 \\
\hline 41 & 0.41 & 42.73 & 124.71 & 0.08 & 0.49 & 0.43 \\
\hline 42 & 0.42 & 42.63 & 124.42 & -0.01 & $0: 44$ & 0.57 \\
\hline 43 & 0.43 & 42.56 & 124.56 & 0.17 & 0.44 & 0.40 \\
\hline 44. & 0.44 & 42.59 & 124.68 & 0.35 & 0.51 & 0.14 \\
\hline 45 & 0.45 & 42.50 & 124.64 & 0.29 & 0.54 & 0.16 \\
\hline 46 & 0.46 & 42.47 & 124.65 & 0.52 & 0.33 & 0.16 \\
\hline 47 & 0.47 & 42.47 & 124.58 & 0.34 & 0.50 & 0.15 \\
\hline 48 & 0.48 & 42.47 & 124.53 & 0.24 & 0.34 & 0.42 \\
\hline 49 & 0.49 & 42.38 & 124.51 & 0.31 & 0.43 & 0.26 \\
\hline 50 & 0.50 & 42.39 & 124.67 & 0.48 & 0.42 & 0.10 \\
\hline 51 & 0.51 & 42.33 & 124.45 & 0.17 & 0.64 & 0.19 \\
\hline 52 & 0.52 & 42.29 & 124.46 & 0.20 & 0.51 & 0.29 \\
\hline 53 & 0.53 & 42.28 & 124.58 & 0.13 & 0.38 & 0.49 \\
\hline 54 & 0.54 & 42.23 & 124.42 & 0.32 & 0.28 & 0.41 \\
\hline 55 & 0.55 & 42.18 & 124.37 & 0.31 & 0.28 & 0.41 \\
\hline 56 & 0.56 & 42.13 & 124.37 & 0.21 & 0.40 & 0.39 \\
\hline
\end{tabular}




$\begin{array}{lcrrrrr} & \text { Sample } & \text { Latilude } & \text { Longitude } & \text { Factor 1 } & \text { Faclor 2 } & \text { Factor 3 } \\ 57 & 0.57 & 42.10 & 124.37 & 0.05 & 0.69 & 0.27 \\ 58 & 0.58 & 41.98 & 124.33 & 0.60 & 0.34 & 0.06 \\ 59 & 0.59 & 41.98 & 124.24 & 0.49 & 0.35 & 0.15 \\ 60 & \text { Agate Beach } & 44.67 & 124.04 & 0.06 & 0.20 & 0.74 \\ 61 & \text { Alsea R. } & 44.42 & 123.59 & 0.37 & 0.51 & 0.12 \\ 62 & \text { Columbia R. } & 46.25 & 123.58 & 0.25 & 0.57 & 0.18 \\ 63 & \text { Coquille R. } & 43.12 & 124.22 & 0.16 & 0.72 & 0.12 \\ 64 & \text { Klamath R. } & 41.54 & 124.04 & 0.74 & 0.26 & 0.00 \\ 65 & \text { Rogue R. } & 42.42 & 124.20 & 0.54 & 0.13 & 0.32 \\ 66 & \text { Siletz R. } & 44.92 & 124.00 & 0.52 & 0.42 & 0.07 \\ 67 & \text { Smith R. } & 41.93 & 124.10 & 0.42 & 0.38 & 0.19 \\ 68 & \text { Umpqua R. } & 43.67 & 124.02 & 0.37 & 0.48 & 0.15\end{array}$




\begin{tabular}{|c|c|c|c|c|c|c|c|}
\hline & Sample & Latilude & Comm. & Factor 1 & Factor 2 & Factor 3 & Faclor 4 \\
\hline 1 & S.1 & 41.00 & 0.83 & 0.33 & 0.20 & 0.60 & 0.56 \\
\hline 2 & $S-2$ & 41.20 & 0.95 & 0.61 & 0.49 & 0.42 & 0.41 \\
\hline 3 & $5 \cdot 3$ & 41.42 & 0.98 & 0.48 & 0.23 & 0.72 & 0.42 \\
\hline 4. & S.4. & 41.59 & 0.99 & 0.49 & 0.20 & 0.77 & 0.34 \\
\hline 5 & $S \cdot 5$ & 41.59 & 0.98 & 0.54 & 0.23 & 0.74 & 0.31 \\
\hline 6 & S.6 & 41.59 & 0.99 & 0.55 & 0.23 & 0.73 & 0.30 \\
\hline 7 & s.7 & 42.08 & 0.97 & 0.38 & 0.20 & 0.80 & 0.38 \\
\hline 8 & S-8 & 42.29 & 0.99 & 0.39 & 0.84 & 0.23 & 0.27 \\
\hline 9 & S.9 & 42.28 & 0.99 & 0.83 & 0.37 & 0.31 & 0.27 \\
\hline 10 & S-10 & 42.58 & 0.98 & 0.58 & 0.32 & 0.58 & 0.46 \\
\hline 11 & 5.11 & 42.56 & 0.97 & 0.56 & 0.27 & 0.62 & 0.45 \\
\hline 12 & S.12. & 42.57 & 0.98 & 0.54 & 0.28 & 0.59 & 0.51 \\
\hline 13 & $S \cdot 13$ & 42.57 & 0.98 & 0.56 & 0.26 & 0.64 & 0.42 \\
\hline 14 & S.14 & 42.53 & 0.99 & 0.52 & 0.43 & 0.53 & 0.50 \\
\hline 15 & 5.15 & 42.87 & 0.98 & 0.35 & 0.87 & 0.23 & 0.24 \\
\hline 16. & S-16 & 42.88 & 0.99 & 0.39 & 0.86 & 0.24 & 0.22 \\
\hline 17 & S-17 & 42.86 & 0.99 & 0.45 & 0.84 & 0.23 & 0.18 \\
\hline 18 & S-18 & $43.16^{\prime}:$ & 0.99 & 0.47 & 0.48 & 0.57 & 0.46 \\
\hline 19 & $S-19$ & 43.20 & 0.99 & 0.48 & 0.73 & 0.28 & 0.39 \\
\hline 20 & S.20 & 43.35 & 0.99 & 0.53 & 0.65 & 0.35 & 0.40 \\
\hline 21 & S-21 & 43.56 & 0.99 & 0.48 & 0.52 & 0.48 & 0.52 \\
\hline 22 & S-22 & 43.56 & 0.99 & 0.46 & 0.59 & 0.40 & 0.52 \\
\hline 23 & $S-23$ & 43.56 & 0.98 & 0.30 & 0.81 & 0.29 & 0.38 \\
\hline 24 & $S-24$ & 44.20 & 0.95 & 0.32 & 0.65 & 0.42 & 0.50 \\
\hline 25 & $S-25$ & 44.39 & 0.99 & 0.42 & 0.65 & 0.41 & 0.47 \\
\hline 26 & S-26 & 44.38 & 0.97 & 0.30 & 0.76 & 0.26 & 0.47 \\
\hline 27 & S.27 & 44.58 & 0.99 & 0.24 & 0.94 & 0.15 & 0.18 \\
\hline 28 & S-28 & 45.11 & 0.99 & 0.39 & 0.56 & 0.38 & 0.61 \\
\hline 29 & $S \cdot 29$ & 45.35 & 0.98 & 0.33 & 0.55 & 0.39 & 0.64 \\
\hline 30 & S.30 & 45.35 & 0.99 & 0.33 & 0.60 & 0.33 & 0.64 \\
\hline 31 & S.31 & 45.35 & 0.98 & 0.31 & 0.63 & 0.35 & 0.61 \\
\hline 32 & $S \cdot 32$ & 45.35 & 0.98 & 0.28 & 0.76 & 0.34 & 0.45 \\
\hline 33 & S-33 & 45.56 & 0.97 & 0.29 & 0.41 & 0.25 & 0.81 \\
\hline 34 & S.34 & 46.20 & 0.97 & 0.33 & 0.56 & 0.20 & 0.72 \\
\hline 35 & $S \cdot 35$ & 46.20 & 0.97 & 0.20 & 0.38 & 0.26 & 0.84 \\
\hline 36 & $S \cdot 37$ & 42.10 & 0.99 & 0.79 & 0.33 & 0.44 & 0.27 \\
\hline 37 & S-38 & 42.15 & 0.98 & 0.43 & 0.25 & 0.78 & 0.37 \\
\hline 38 & S-39 & 42.15 & 0.98 & 0.87 & 0.38 & 0.17 & 0.20 \\
\hline 39 & $S-40$ & 42.21 & 0.75 & 0.69 & 0.29 & 0.34 & 0.26 \\
\hline 40 & S.41. & 42.35 & 1.00 & 0.83 & 0.35 & 0.35 & 0.26 \\
\hline 41 & $S .43$ & 42.35 & 0.99 & 0.78 & 0.31 & 0.44 & 0.32 \\
\hline 42 & $S-44$ & 42.36 & 0.99 & 0.78 & $0: 32$ & 0.44 & 0.30 \\
\hline 43 & $S .45$ & 42.39 & 0.98 & 0.81 & 0.33 & 0.36 & 0.30 \\
\hline 44 & S. 46 & 42.39 & 0.97 & 0.68 & 0.35 & 0.46 & 0.42 \\
\hline 45 & $S-47$ & 42.23 & 0.83 & 0.58 & 0.41 & 0.41 & 0.41 \\
\hline 46 & S-48 & 42.40 & 0.99 & 0.68 & 0.31 & 0.54 & 0.39 \\
\hline 47 & S-49 & 42.40 & 0.99 & 0.68 & 0.34 & 0.44 & 0.46 \\
\hline 48 & $S \cdot 50$ & 42.42 & 0.98 & 0.68 & 0.33 & 0.47 & 0.44 \\
\hline 49 & S.51 & 42.42 & 0.95 & 0.66 & 0.38 & 0.40 & 0.47 \\
\hline 50 & S.52 & 42.25 & 0.97 & 0.65 & 0.36 & 0.45 & 0.47 \\
\hline 51 & 5.53 & 42.47 & 0.99 & 0.57 & 0.34 & 0.53 & 0.51 \\
\hline 52 & S-54 & 42.47 & 0.99 & 0.61 & 0.35 & 0.48 & 0.51 \\
\hline 53 & S.55 & 42.57 & 0.94 & 0.69 & 0.15 & 0.49 & 0.46 \\
\hline 54 & 5.56 & 42.58 & 0.98 & 0.59 & 0.30 & 0.60 & 0.43 \\
\hline 55 & S-57 & 42.38 & 0.99 & 0.56 & 0.33 & 0.52 & 0.55 \\
\hline 56 & S.58 & 42.38 & 0.94 & 0.74 & 0.46 & 0.32 & 0.27 \\
\hline
\end{tabular}




\begin{tabular}{|c|c|c|c|c|c|c|c|}
\hline & Sample & Latitude & Comm. & Factor 1 & Factor 2 & Factor 3 & Facior 4 \\
\hline 57 & $S .59$ & 42.41 & 0.99 & 0.50 & 0.59 & 0.38 & 0.50 \\
\hline 58 & S.60 & 42.44 & 0.99 & 0.52 & 0.59 & 0.39 & 0.45 \\
\hline 59 & S.61 & 42.76 & 0.98 & 0.39 & 0.81 & 0.26 & 0.31 \\
\hline 60 & S.62 & 43.11 & 0.99 & 0.52 & 0.61 & 0.43 & 0.41 \\
\hline 61 & S-63 & 43.11 & 0.94 & 0.32 & 0.71 & 0.20 & 0.55 \\
\hline 62 & $S .65$ & 43.12 & 0.97 & 0.40 & 0.80 & 0.21 & 0.34 \\
\hline 63 & S.66 & 43.29 & 0.99 & 0.55 & 0.32 & 0.49 & 0.59 \\
\hline 64 & S.67 & 43.35 & 0.98 & 0.43 & 0.45 & 0.42 & 0.65 \\
\hline 65 & 5.68 & 43.44 & 0.98 & 0.37 & 0.69 & 0.25 & 0.55 \\
\hline 66 & S. 69 & 44.20 & 0.95 & 0.30 & 0.87 & 0.17 & 0.28 \\
\hline 67 & s.70 & 44.59 & 0.96 & 0.43 & 0.47 & 0.40 & 0.62 \\
\hline 68 & S-71 & 44.59 & 0.97 & 0.34 & 0.64 & 0.31 & 0.59 \\
\hline 69 & S-72 & 44.59 & 1.00 & 0.23 & 0.94 & 0.14 & 0.17 \\
\hline 70 & 5.73 & 45.14 & 0.99 & 0.23 & 0.94 & 0.15 & 0.21 \\
\hline 71 & OR-1 & 43.41 & 0.99 & 0.50 & 0.59 & 0.39 & 0.49 \\
\hline 72 & OR-2 & 43.50 & 0.99 & 0.30 & 0.66 & 0.39 & 0.56 \\
\hline 73 & OR-3 & 44.05 & 0.98 & 0.27 & 0.88 & 0.18 & 0.32 \\
\hline 74 & OR-4 & 44.05 & 0.99 & 0.40 & 0.76 & 0.31 & 0.39 \\
\hline 75 & OR.5 & 44.72 & 0.96 & 0.28 & 0.70 & 0.38 & 0.50 \\
\hline 76 & OR-6 & 44.72 & 0.98 & 0.27 & 0.79 & 0.21 & 0.49 \\
\hline 77 & OR-7 & 44.72 & 0.99 & 0.35 & 0.62 & 0.45 & 0.53 \\
\hline 78 & OR-7A & 45.20 & 0.99 & 0.26 & 0.90 & 0.19 & 0.28 \\
\hline 79 & OR-8 & 45.29 & 0.90 & 0.30 & 0.67 & 0.39 & 0.55 \\
\hline 80 & OR.9 & 45.29 & 0.99 & 0.28 & $0: 81$ & 0.23 & 0.46 \\
\hline 81 & OR-10 & 45.29 & 0.99 & 0.30 & 0.67 & 0.34 & 0.57 \\
\hline 82 & OR-11 & 45.29 & 0.98 & 0.26 & 0.41 & 0.42 & 0.75 \\
\hline 83 & OA-12 & 45.47 & 0.99 & 0.31 & 0.48 & 0.34 & 0.74 \\
\hline 84 & OR-13 & 45.47 & 0.94 & 0.24 & 0.62 & 0.21 & 0.67 \\
\hline 85 & OR-14 & 45.53 & 0.99 & 0.30 & 0.72 & 0.34 & 0.52 \\
\hline 86 & OA.15 & 45.56 & 0.98 & 0.28 & 0.47 & 0.32 & 0.76 \\
\hline 87 & OR-16 & 46.02 & 0.99 & 0.33 & 0.51 & 0.34 & 0.71 \\
\hline 88 & B.11 & 40.70 & 0.89 & 0.83 & 0.34 & 0.18 & 0.23 \\
\hline 89 & $8-12$ & 41.04 & 0.92 & 0.70 & 0.53 & 0.21 & 0.32 \\
\hline 90 & B.13 & 41.36 & 0.94 & 0.77 & 0.44 & 0.23 & 0.31 \\
\hline 91 & B-14 & 41.47 & 0.95 & 0.83 & 0.46 & 0.05 & 0.23 \\
\hline 92 & B.15 & 41.73 & 0.97 & 0.85 & 0.41 & 0.24 & 0.14 \\
\hline 93 & B.16 & 41.86 & 0.96 & 0.80 & 0.31 & 0.41 & 0.22 \\
\hline 94 & B. 17 & 42.02 & 0.95 & 0.91 & 0.28 & 0.13 & 0.16 \\
\hline 95 & TB.3 & 42.32 & 0.96 & 0.89 & 0.36 & 0.07 & 0.17 \\
\hline 96 & B.18 & 42.37 & 0.97 & 0.88 & 0.33 & 0.23 & 0.20 \\
\hline 97 & B-19 & 42.50 & 0.95 & 0.88 & 0.34 & 0.17 & 0.17 \\
\hline 98 & TB-8 & 42.73 & 0.94 & 0.41 & 0.83 & 0.17 & 0.24 \\
\hline 99 & B.20 & 42.84 & 0.96 & 0.61 & 0.73 & 0.16 & 0.17 \\
\hline 100 & 8.21 & 43.21 & 0.95 & 0.44 & 0.84 & 0.15 & 0.19 \\
\hline 101 & 8.22 & 44.03 & 0.89 & 0.23 . & 0.89 . & 0.08 & 0.22 \\
\hline 102 & $B-23$ & 44.67 & 0.96 & $0.25^{\circ}$ & 0.93 & 0.12 & 0.10 \\
\hline 103 & $B-24$ & 45.01 & 0.99 & 0.21 & 0.96 & 0.16 & 0.08 \\
\hline 104 & TB-5 & 45.31 & 0.90 & 0.32 & 0.86 & 0.09 & 0.20 \\
\hline 105 & TB-4 & 45.72 & 0.80 & 0.35 & 0.81 & 0.03 & 0.15 \\
\hline 106 & 8.25 & 45.91 & 0.94 & 0.42 & 0.80 & 0.13 & 0.33 \\
\hline 107 & 8.26 & 46.22 & 0.92 & 0.46 & 0.58 & 0.20 & 0.58 \\
\hline 108 & $R \cdot 11$ & 40.62 & 0.96 & 0.72 & 0.29 & 0.38 & 0.47 \\
\hline 109 & $R=12$ & 40.93 & 0.89 & 0.83 & 0.30 & 0.16 & 0.29 \\
\hline 110 & R.13 & 41.54 & 0.98 & 0.88 & 0.33 & 0.19 & 0.24 \\
\hline 111 & $R \cdot 14$ & 41.93 & 0.91 & 0.91 & 0.13 & 0.25 & 0.12 \\
\hline 112 & $R \cdot 15$ & 42.05 & 0.97 & 0.45 & 0.25 & 0.80 & 0.24 \\
\hline
\end{tabular}




\begin{tabular}{|c|c|c|c|c|c|c|c|}
\hline & Sample & Latitude & comm. & Factor 1 & Factor 2 & Faclor 3 & Factor 4 \\
\hline 113 & $R \cdot 16$ & 42.27 & 0.91 & 0.80 & 0.18 & 0.21 & 0.44 \\
\hline 114 & R-17 & 42.42 & 0.98 & 0.81 & 0.36 & 0.30 & 0.32 \\
\hline 115 & $R-18$ & 42.79 & 0.93 & 0.58 & 0.32 & 0.28 & 0.65 \\
\hline 116 & R.19 & 42.85 & 0.92 & 0.88 & 0.22 & 0.21 & 0.22 \\
\hline 117 & R-20 & 43.12 & 0.90 & 0.58 & 0.62 & 0.24 & 0.36 \\
\hline 118 & R.21 & 43.67 & 0.97 & 0.42 & 0.59 & 0.29 & 0.60 \\
\hline 119 & R.22 & 44.01 & 0.98 & 0.20 & 0.92 & 0.04 & 0.30 \\
\hline 120 & R-23 & 44.42 & 0.98 & 0.21 & 0.91 & 0.14 & 0.29 \\
\hline 121 & $R \cdot 24$ & 44.92 & 0.95 & 0.15 & 0.95 & 0.12 & 0.12 \\
\hline 122. & $R \cdot 25$ & 45.15 & 0.91 & 0.31 & 0.58 & 0.24 & 0.64 \\
\hline 123 & $R \cdot 26$ & 45.45 & 0.92 & 0.26 & 0.46 & 0.42 & 0.68 \\
\hline 124 & R-27 & 45.65 & 0.94 & 0.37 & 0.56 & 0.35 & 0.61 \\
\hline 125 & $R \cdot 28$ & 46.25 & 0.73 & 0.33 & 0.40 & 0.26 & 0.62 \\
\hline
\end{tabular}


APPENDIX C

CONTOUR MAPS 


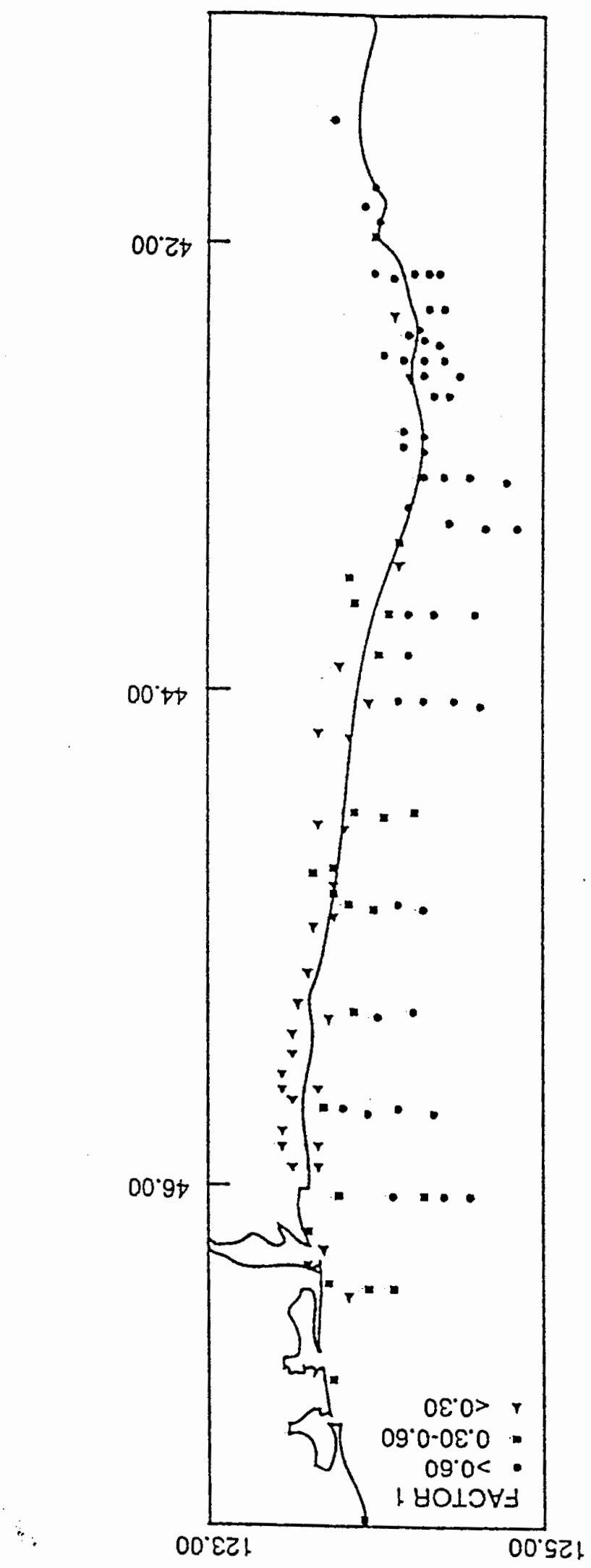




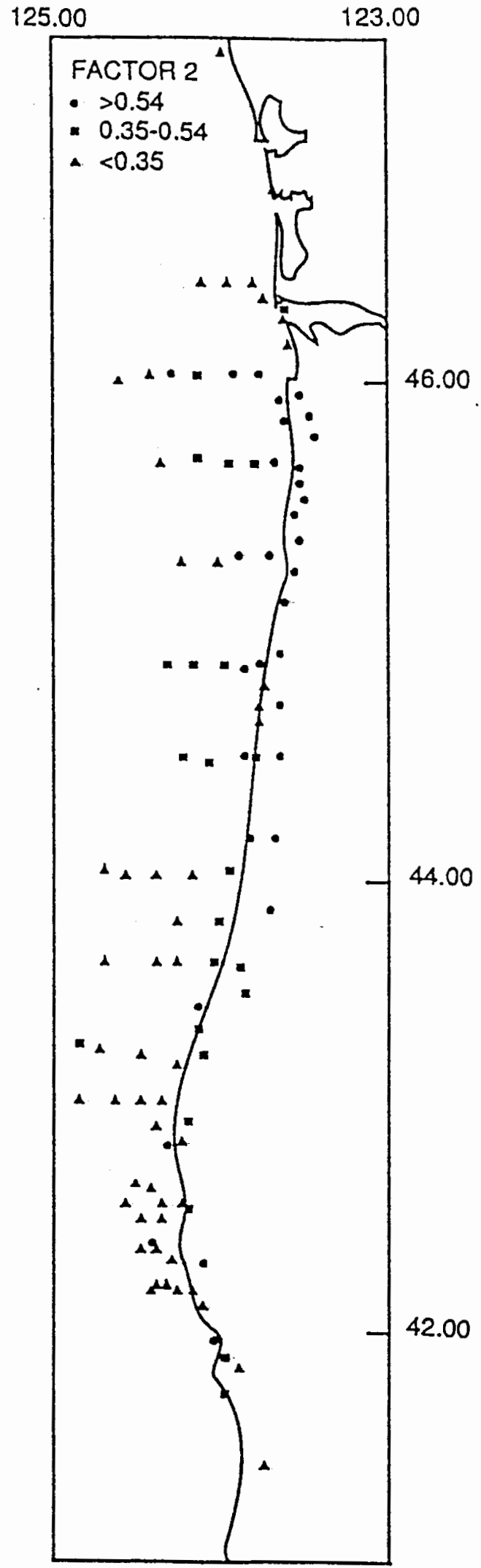


139

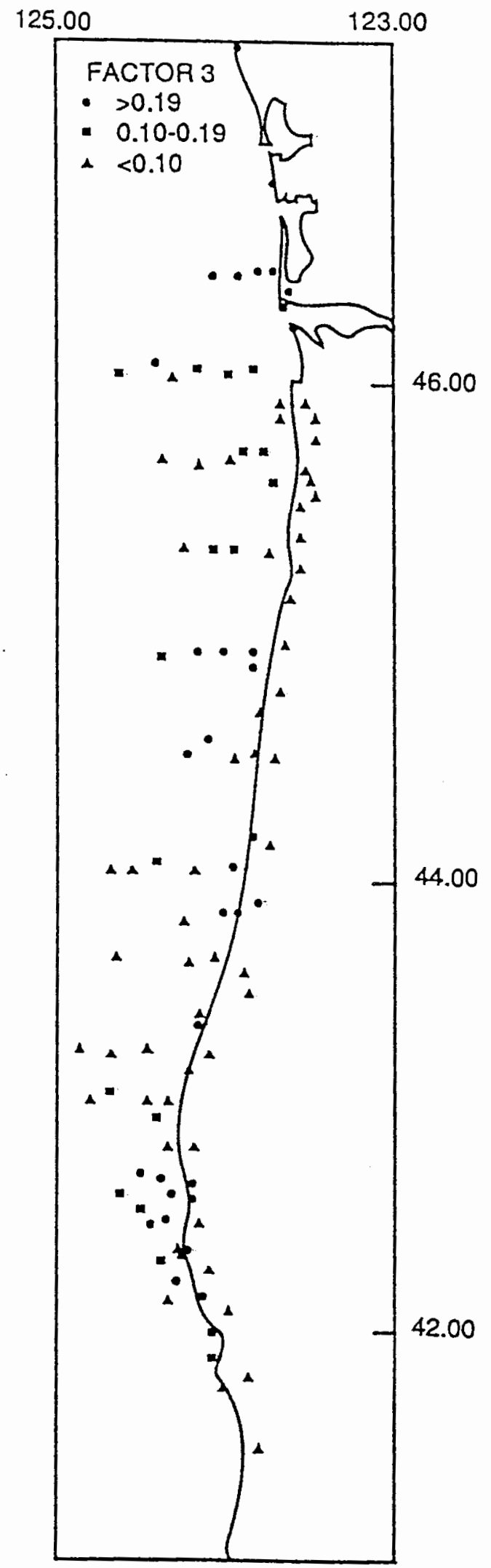




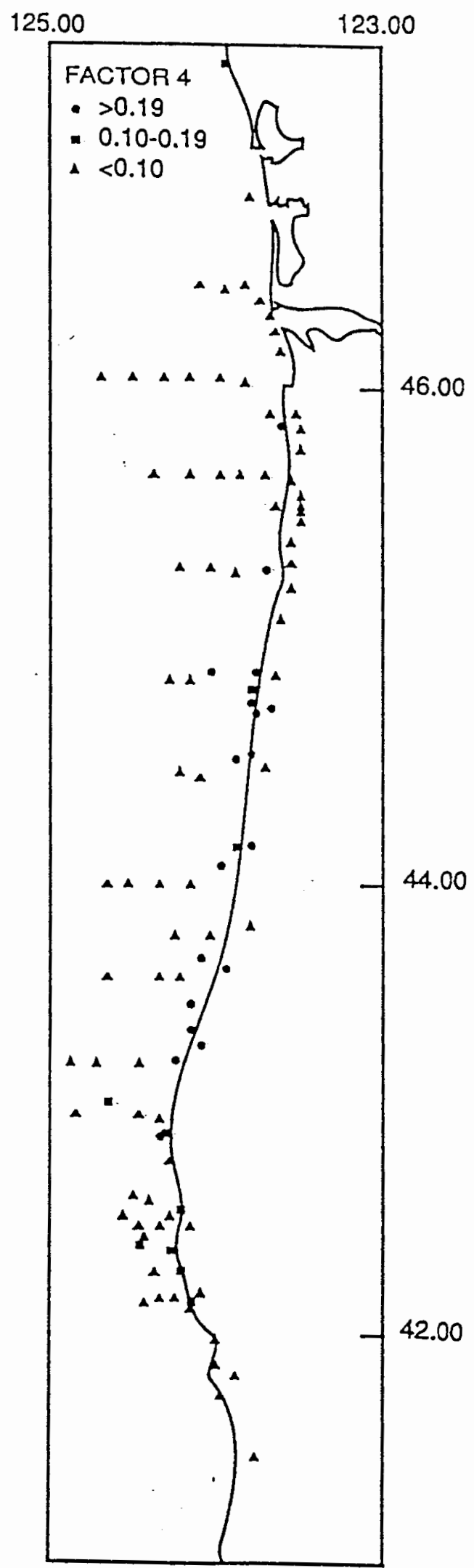


END-MEMBER ONE DISTRIBUTION (G. K. SWILLEY, 1986)

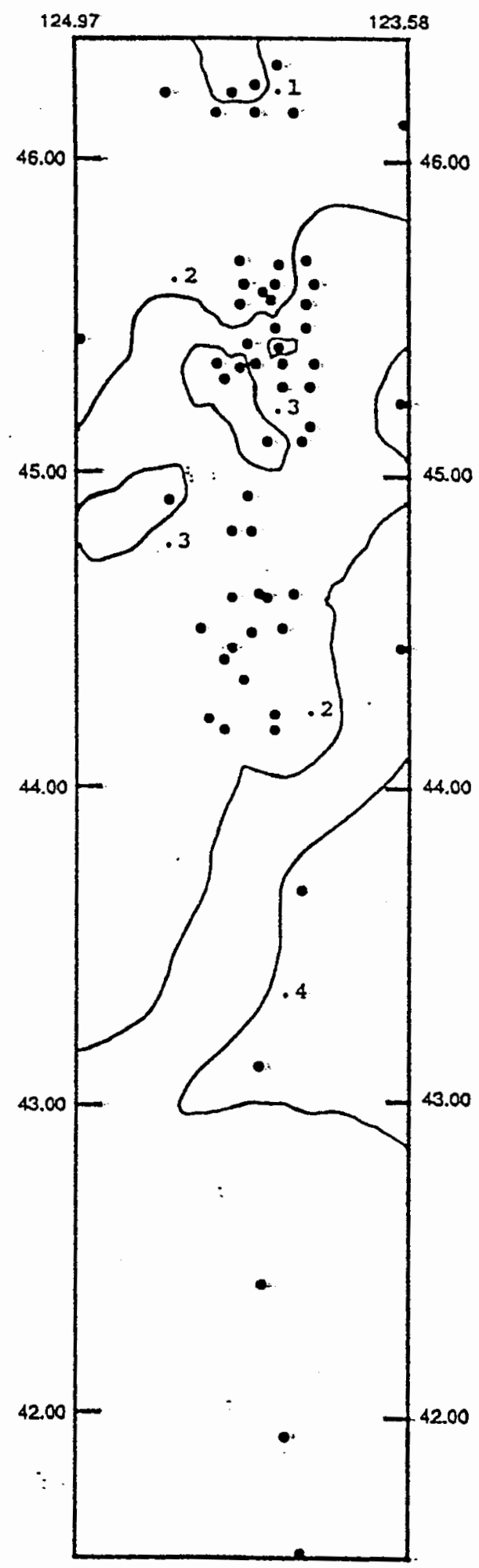

CONTOUR INTERVAL . I 
END-MEMBER TWO DISTRIBUTION (G. K. SWIILEY, 1986)

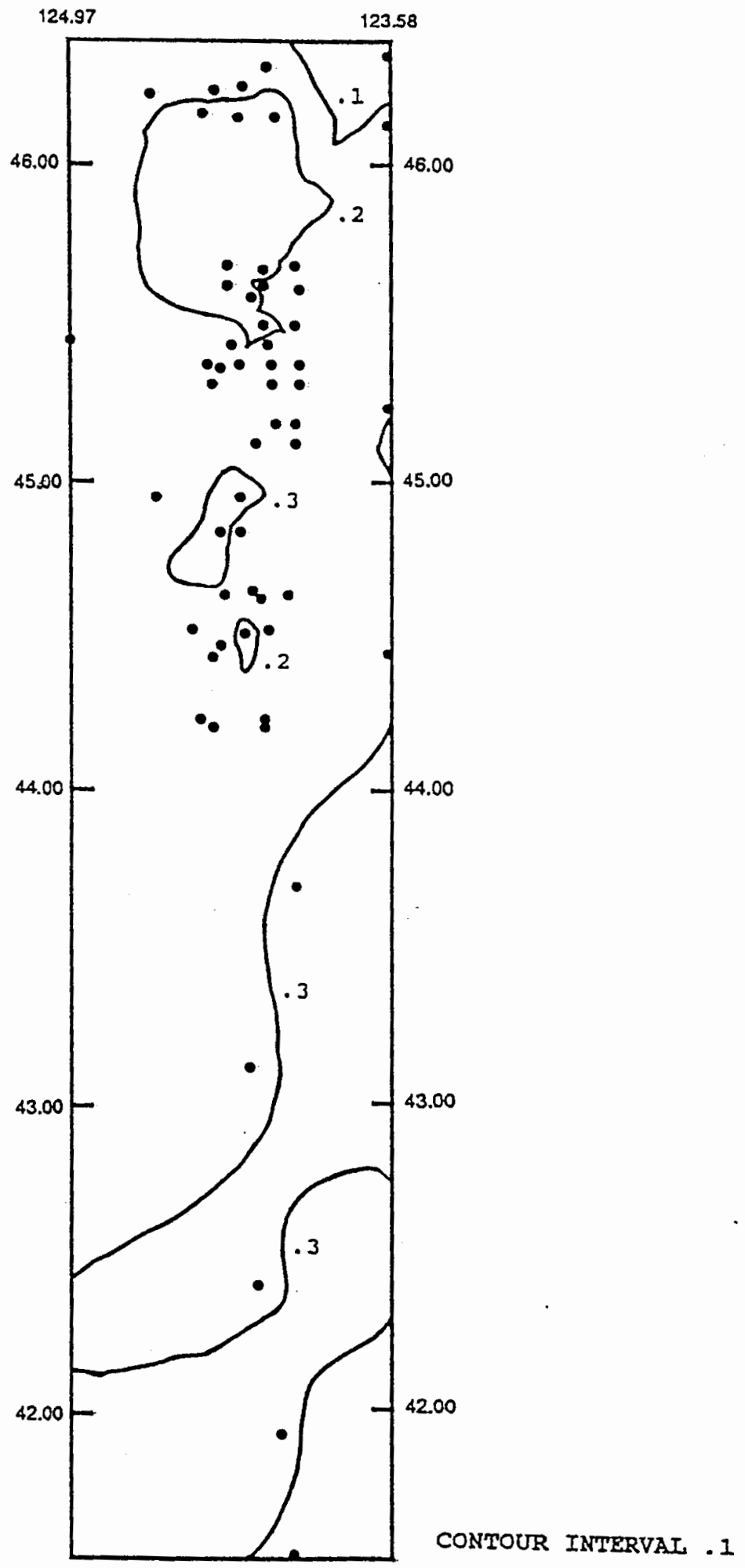


END-MEMBER THREE DISTRIBUTION (G. K. SWILISY, 1986)

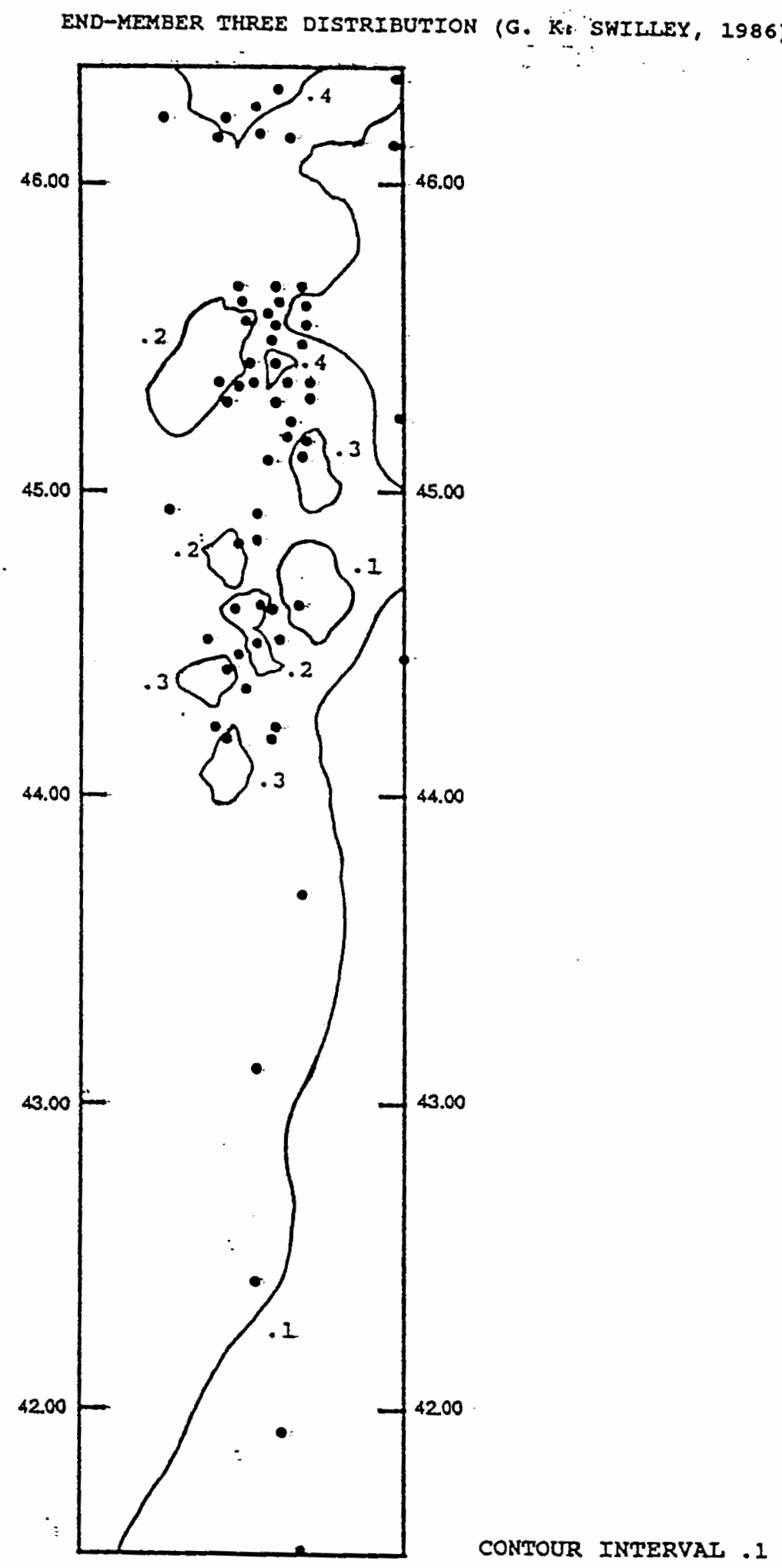

$\because$ 
144

END-MEMBER FOUR DISTRIBUTION (G. K. SWILIEY, 1986)

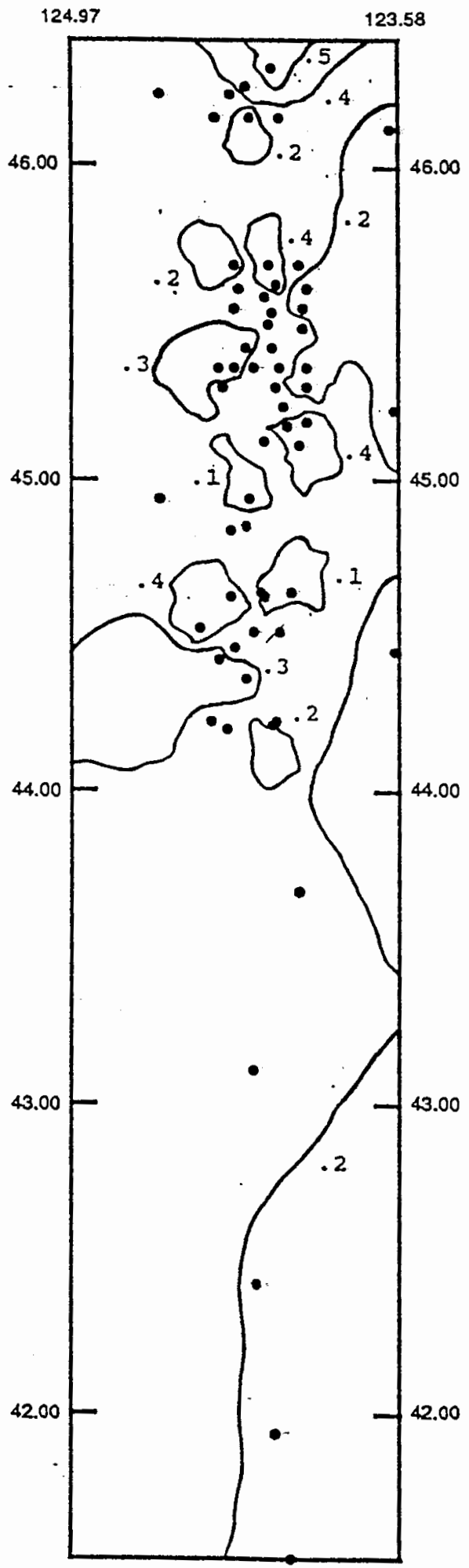

CONTOUR INTERVAL . I 
FOURIER GRAIN-SHAPE ANALYSIS OF QUARTZ GRAINS

END-MEMBER ONE DISTRIBUTION (M. A. O'NEAL, 1986)

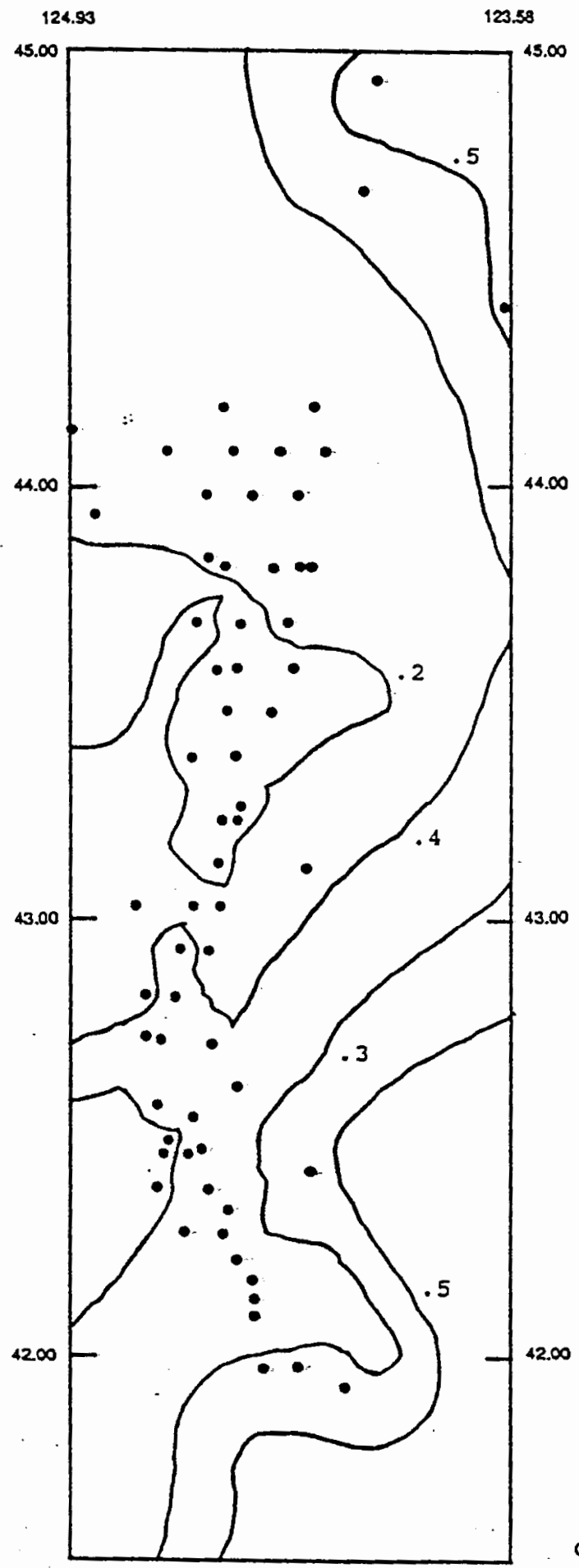


END-MEMBER TWO DISTRIBUTION (M. A. O'NEAL, 2986)

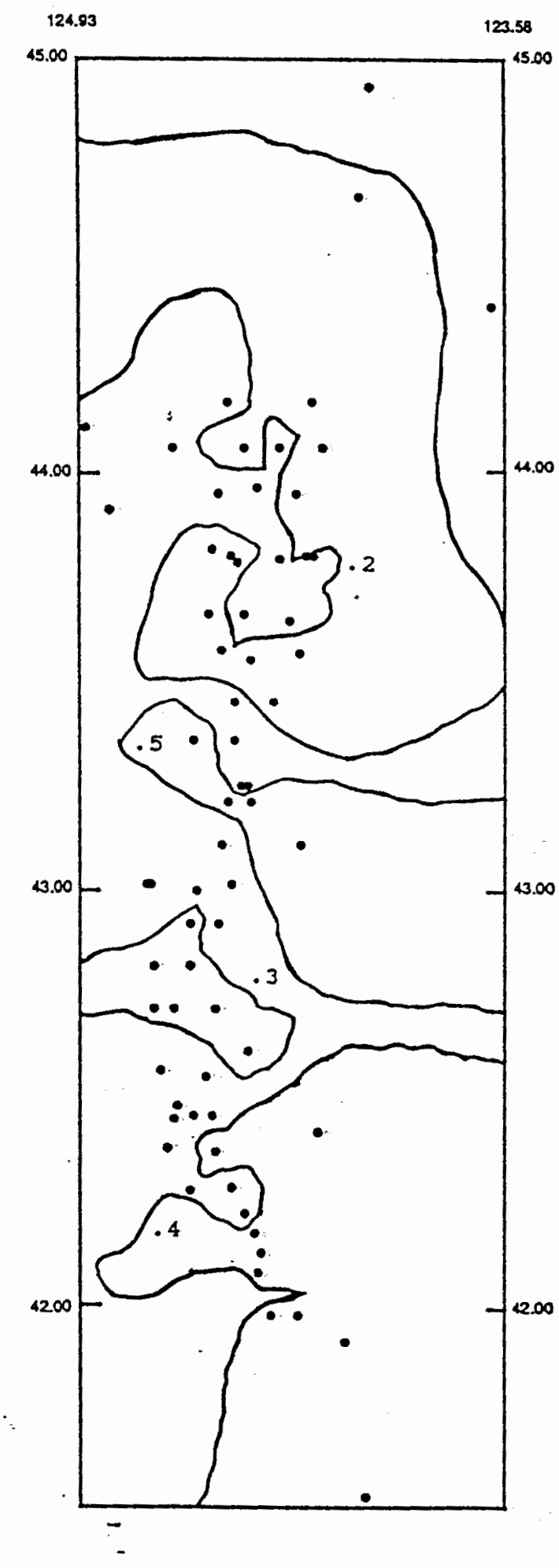


END-MEMBER THREE DISTRIBUTION (M. A. O'NEAL, 1986)

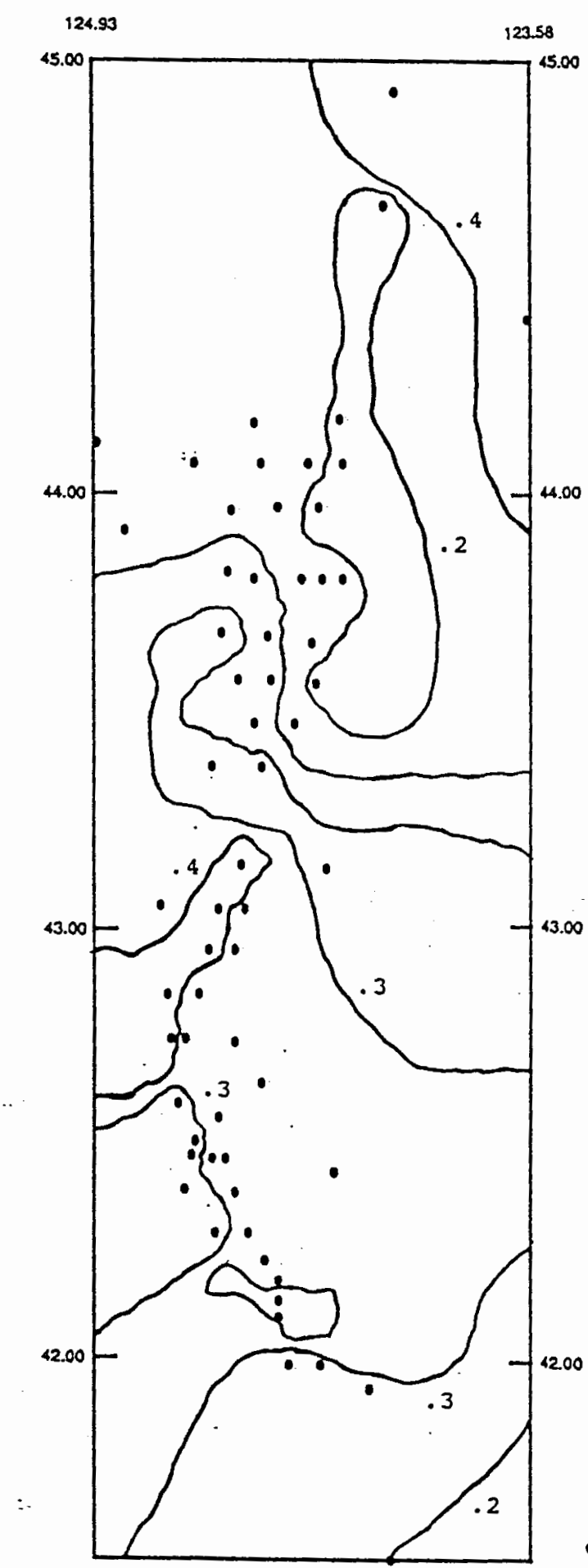

CONTOUR INTERVAI . I 
SHELE-BEACH-RIVER COMBINED GEOCREMICAL ANALYSIS OF OPAQUE OXIDES END-MEMBER ONE DISTRIBUTION (K. S. RAVI, 1992)

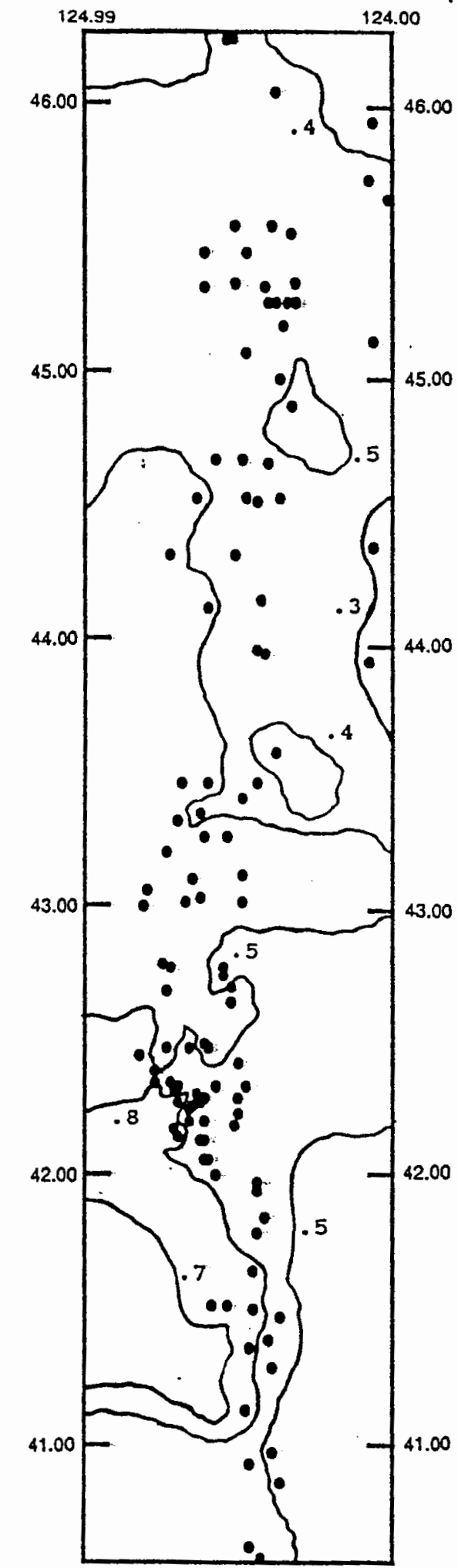

CONTOUR INTERVAL .1 
END-MEMBER TWO DISTRIBUTION (K. S. RAVI, 1992)

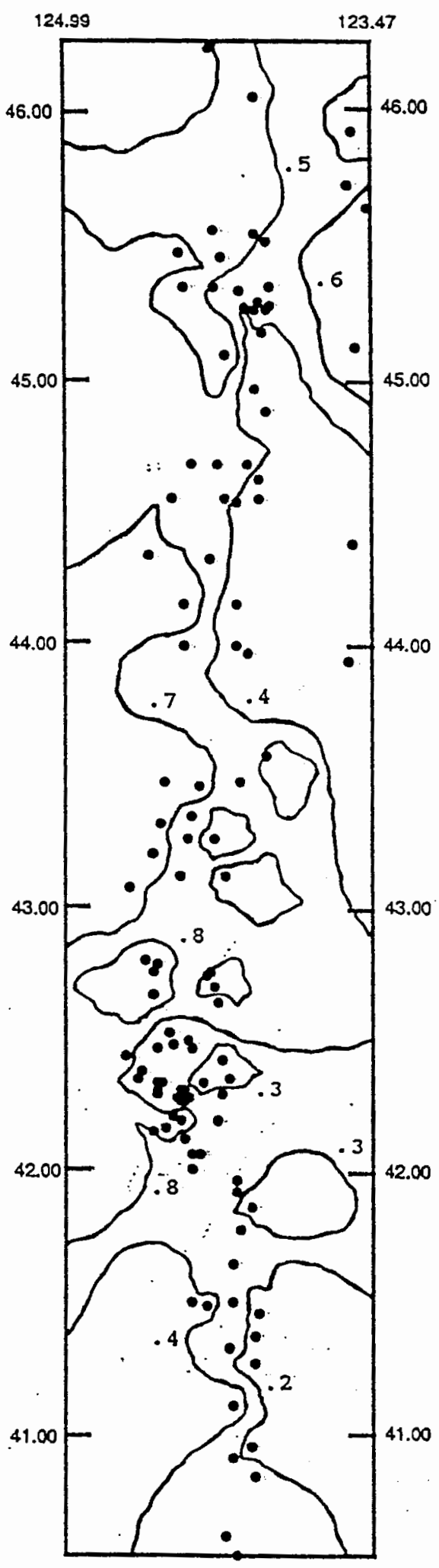

CONTOUR INTERVAI I I 
END-MEMBER THREE DISTRIBUTION (K. S. RAVI, 1992)

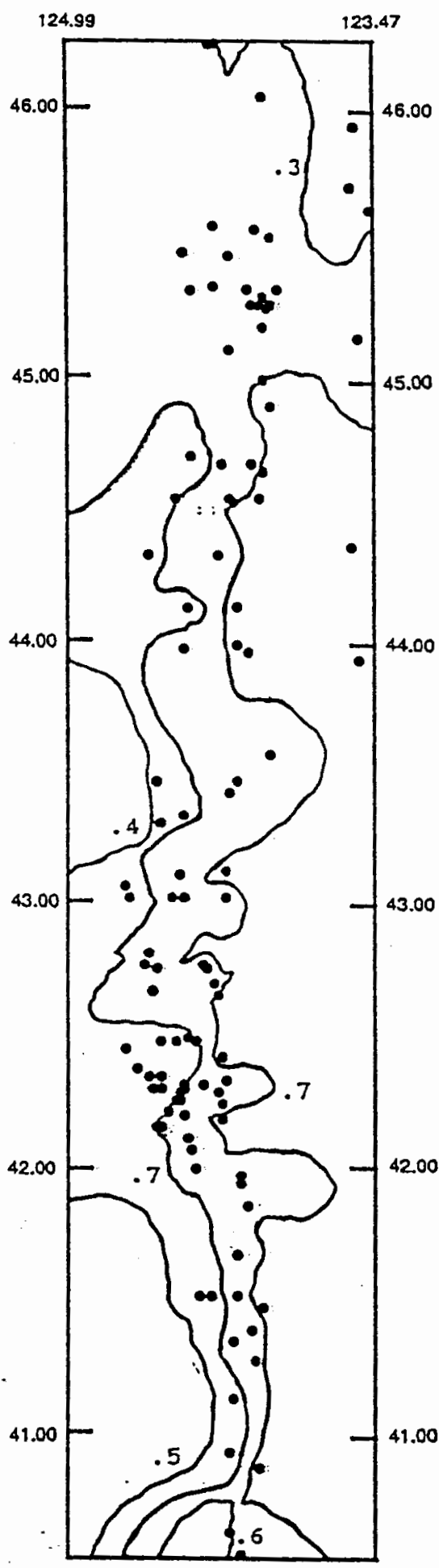

CONTOUR INTERVAL .1 
END-MEMBER FOUR DISTRIBUTION (K. S. RAVI, 1992)

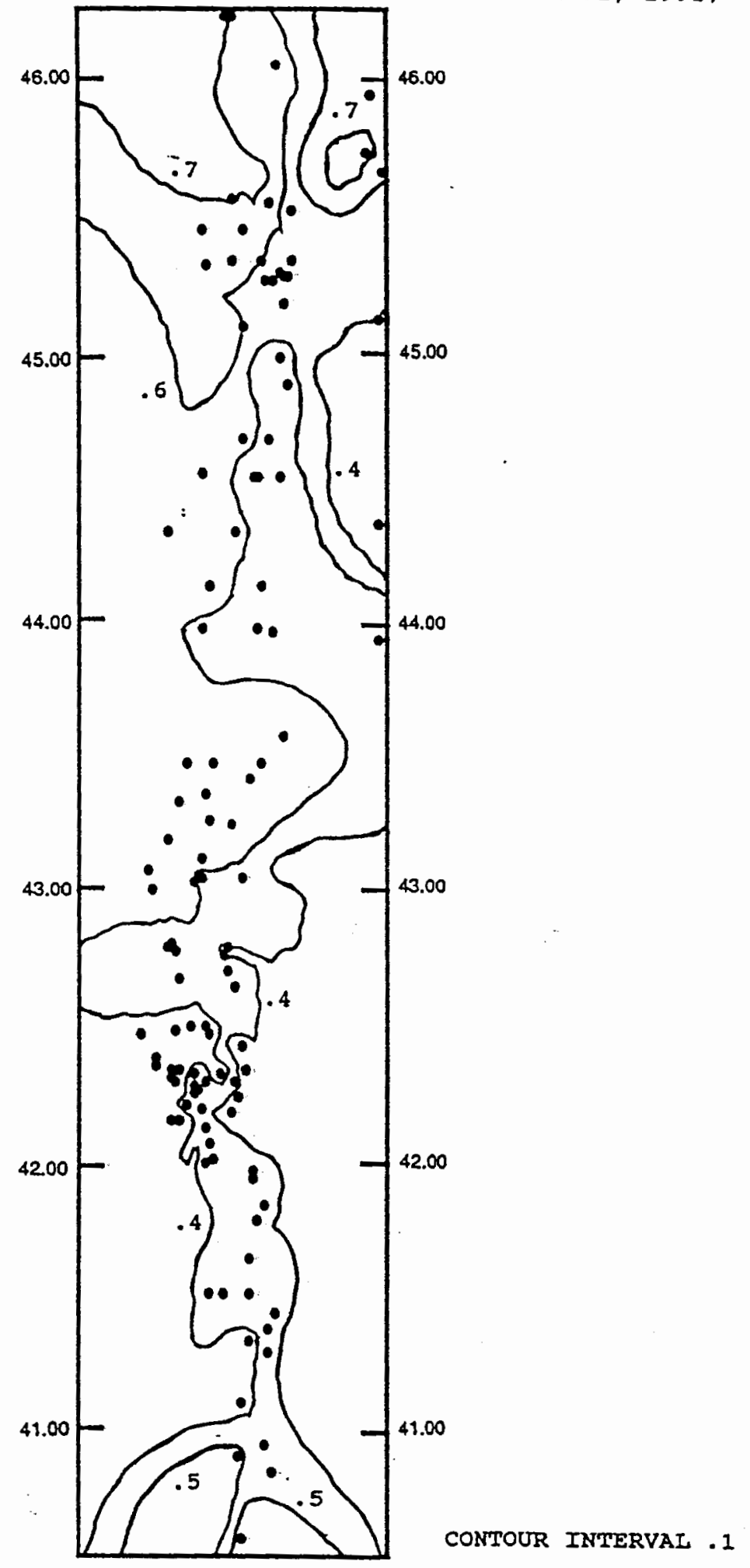

